\title{
Vertification of the AXAIR89Q Dose Assessment Code
}

by

\section{A Blanchard}

Westinghouse Savannah River Company

Savannah River Site

Aiken, South Carolina 29808

J. Hudson

D. M. Hamby

This paper was prepared in connection with work done under the above contract number with the $U$. S.

Department of Energy. By acceptance of this paper, the publisher and/or recipient acknowledges the U. S. Government's right to retain a nonexclusive, royalty-free license in and to any copyright covering this paper, along with the right to reproduce and to authorize others to reproduce all or part of the copyrighted paper.
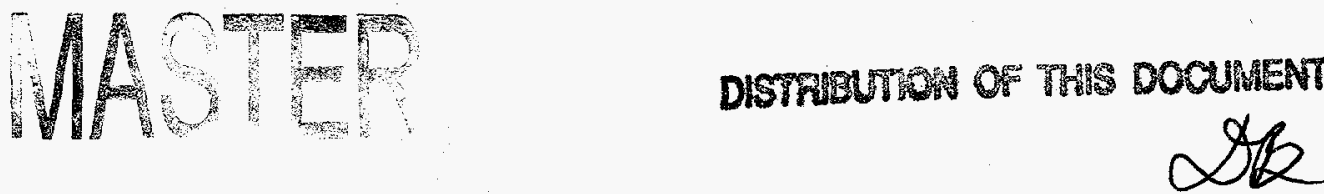


\section{DISCLAIMER}

This report was prepared as an account of work sponsored by an agency of the United States Government. Neither the United States Government nor any agency thereof, nor any of their employees, makes any warranty, express or implied, or assumes any legal liability or responsibility for the accuracy, completeness, or usefulness of any information, apparatus, product, or process disclosed, or represents that its use would not infringe privately owned rights. Reference herein to any specific commercial product, process, or service by trade name, trademark, manufacturer, or otherwise does not necessarily constitute or imply its endorsement, recommendation, or favoring by the United States Government or any agency thereof. The views and opinions of authors expressed herein do not necessarily state or reflect those of the United States Government or any agency thereof.

This report has been reproduced directly from the best available copy.

Available to DOE and DOE contractors from the Office of Scientific and Technical Information, P.O. Box 62, Oak Ridge, TN 37831; prices available from (615) 576-8401.

Available to the public from the National Technical Information Service, U.S. Department of Commerce, 5285 Port Royal Road, Springfield, VA 22161. 


\section{DISCLAIMER}

Portions of this document may be illegible electronic image products. Images are produced from the best available original document. 
WSRC-RP-90-1222

VERIFICATION OF THE AXAIR89Q DOSE ASSESSMENT CODE (U)

D.M. Hamby

Publication Date: November 12, 1990

Westinghouse Savannah River Company

Savannah River Site

Aiken, SC 29808

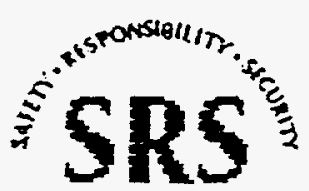




\section{CONTENTS}

Introduction

Summary

Organization 2

Atmospheric Transport 11

Internal Dosimetry 26

External Dosimetry 29

Databases 36

References 38

Appendix A

Appendix B

Appendix C 


\section{LIST OF FIGURES}

3.1 AXAIR89Q module execution sequence.......................................................... 3

3.2 Subroutine paths for the AXAIN89 module ................................................... 4

3.3 Subroutine paths for the AXATERL module ................................................. 5

3.4 Subroutine paths for the AXAPOP89 module ............................................... 6

3.5 Subroutine paths for the AXAMET89 module ............................................. 7

3.6 Subroutine paths for the PRIMUSL module ………........................................ 8

3.7 Subroutine paths for the AXADOS89 module .............................................. 10

5.1 Offsite population dose calculation: inhalation of tritium oxide ................. 30

6.1 Offsite population dose calculation for external exposure to Ar-41 .......... 33

\section{LIST OF TABLES}

4.1 Wind speed category ranges ...................................................................... 11

4.2 Wind stability categories ............................................................................... 12

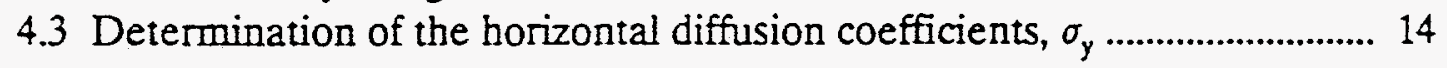

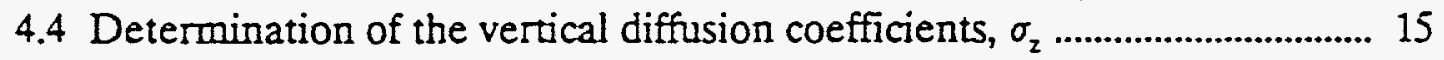

4.5 Empirically derived power law exponents describing vertical variation in wind speed at the SRS ....................................................... 15

4.6 Results of hand calculations for two-hour and annual average relative concentration: stack releases

4.7 Comparison of observed to predicted tritium oxide concentrations in air at the SRS boundary

4.8 Results of hand calculations for two-hour and annual average relative concentration: vent releases

4.9 Results of hand calculations for two-hour centerline, two-hour sector-arc and sector-arc annual average concentrations 25

5.1 Comparison of inhalation dose: AXAIR89Q to hand-calculations..................28

6.1 Comparison of external dose: AXAIR89Q to hand-calculations......................31

6.2 External shine dose using AXAIR89Q's three plume models............................35

7.1 Data files accessed by AXAIR89Q routines ....................................................... 37 


\title{
VERIFICATION OF THE AXAIR89Q DOSE ASSESSMENT CODE
}

\author{
By D.M. Hamby \\ Westinghouse Savannah River Company \\ Savannah River Site \\ Aiken, SC 29808
}

\section{INTRODUCTION}

AXAIR89Q was developed at SRL to model atmospheric transport and radiological dosimetry for postulated atmospheric releases of short duration. The dispersion and dosimetry models used by the code are essentially those described in NRC Regulatory Guides 1.145 and 1.109 , respectively. AXAIR89Q accommodates stack and vent releases. The code produces fifty-year dose commitments to individuals and populations based on the inhalation and plume gamma-shine exposure pathways.

This verification report has been prepared to show that AXAIR89Q is properly coded to execute algorithms and to transfer data. Hand calculations were performed for a number of scenarios covering a wide range of release conditions. Scenarios were designed to provide rigorous tests of calculational routines, i.e., the probability of occurrence was not considered.

\section{SUMMARY}

A brief description of AXAIR89Q's organization is given in Section 3 followed by discussions of the dispersion and dosimetry models in Sections 4,5 and 6. The quality assurance reviews of several databases are described in the final section. Hand-calculations of dispersion and dosimetry parameters are given in the appendices.

Results from hand-calculations of individual and population dose compare favorably with AXAIR89Q results for the release scenarios considered. Computer estimates of relative air concentration, inhalation dose and uniform plume, gamma-shine dose are all within $1 \%$ of values determined by hand. Algorithms for the non-uniform plume, external shine integrals are consistent with empirical solutions derived by the designer. 


\section{ORGANIZATION}

The AXAIR89Q computer program is designed to provide dose estimates to individuals and populations exposed to radioactive materials following an unplanned release from facilities at the Savannah River Site. The complete AXAIR89Q package is comprised of six modules. The modules, in their sequence of execution, are shown in Figure 3.1. The subroutines of each module are shown in Figures 3.2 through 3.7. A brief description of each module is given below. A complementary description of the entire AXAIR89Q program can be found in reference 1.

AXAIN89. This module reads user input data and archived data files and writes temporary files for use by one or more of the remaining modules. AXAIN89 determines minimum boundary distances in each of 16 sectors relative to the release point. This module also reads windspeed and joint frequency meteorological data and writes these data as the percentage of total time the wind is blowing in a given direction with a given stability and speed.

AXATERL. The AXATERL module reads terrain data from an Oak Ridge National Laboratory binary data base and generates an array by compass sector of maximum relative terrain heights at eleven distinct distances (out to 50 miles). The array is generated in concentric rings about the release point.

AXAPOP89. This module generates a temporary file of the projected offsite population (for a user-specified year) by sector and radial distance with respect to the release location. For purposes of the inhalation dose calculation for the 50-mile population, the population is distributed by age group as follows: Adult $68.3 \%$, Teen $9.0 \%$, and Child $22.7 \%$. AXAPOP89 also calculates an array of the onsite population (all adult) in the same format.

AXAMET89. Relative concentrations in air are calculated in the AXAMET89 module for all user-specified sectors and distances. Section 4 of this report describes the methodology used in these calculations.

PRIMUSL. The PRIMUSL module prepares the radionuclide daughter ingrowth library from all nuclides specified in the source term. PRIMUSL is a modified version of PRIMUS'2. Modifications to PRIMUS are only those required for compilation on the IBM 3083 and compatibility with the other AXAIR89Q modules. A reference copy of ORNL-5912 can be found in the QA files maintained by the Environmental Dosimetry Group. 
Figure 3.1. AXAIR89Q Module Execution Sequence

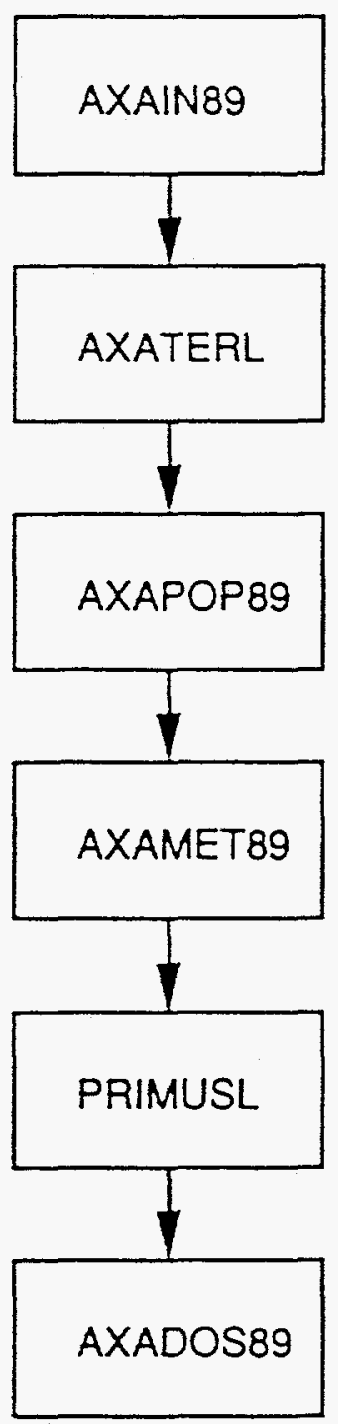


Figure 3.2. Subroutine Paths for the AXAIN89 Module

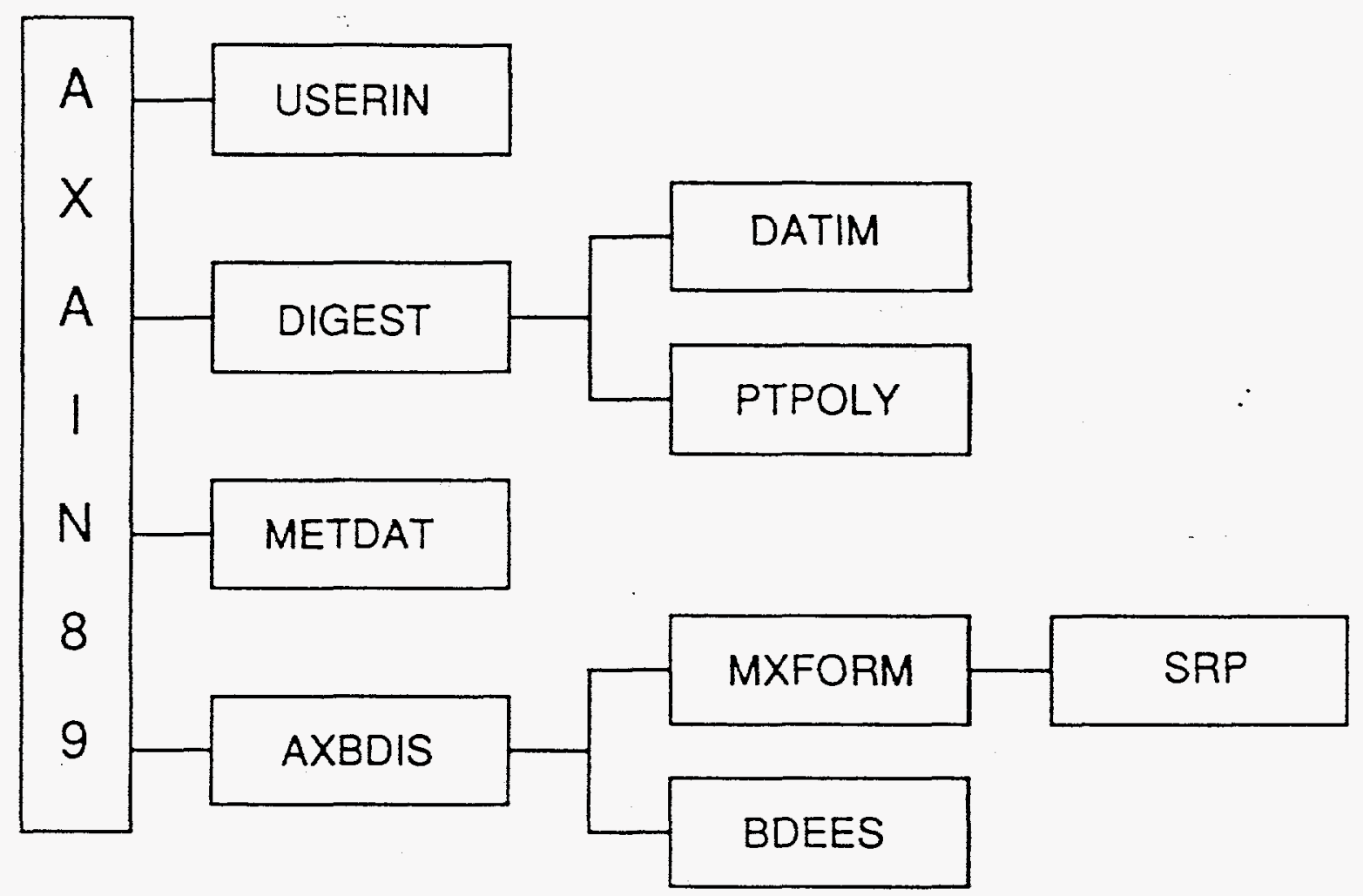


Figure 3.3. Subroutine Paths for the AXATERL Module

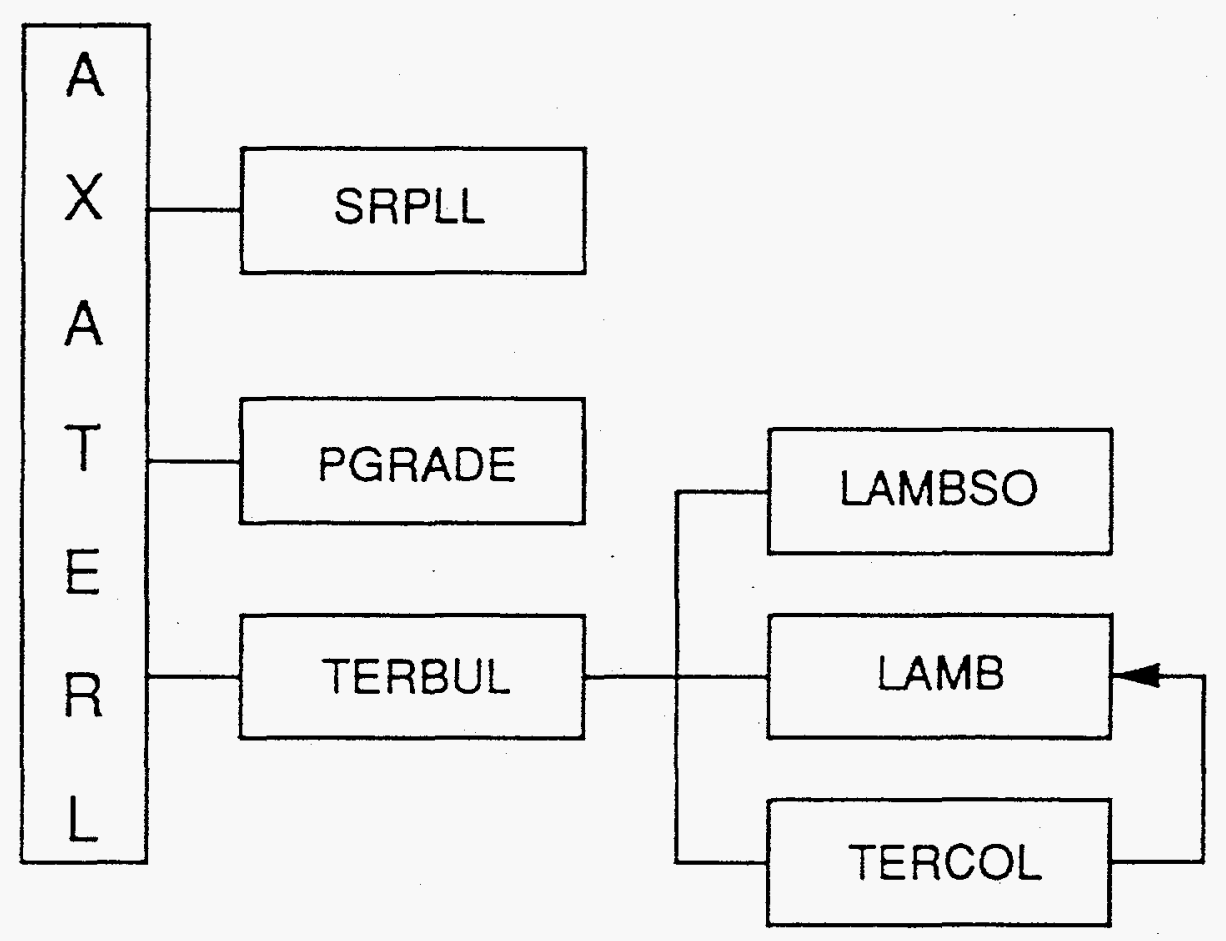


Figure 3.4. Subroutine Paths for the AXAPOP89 Module

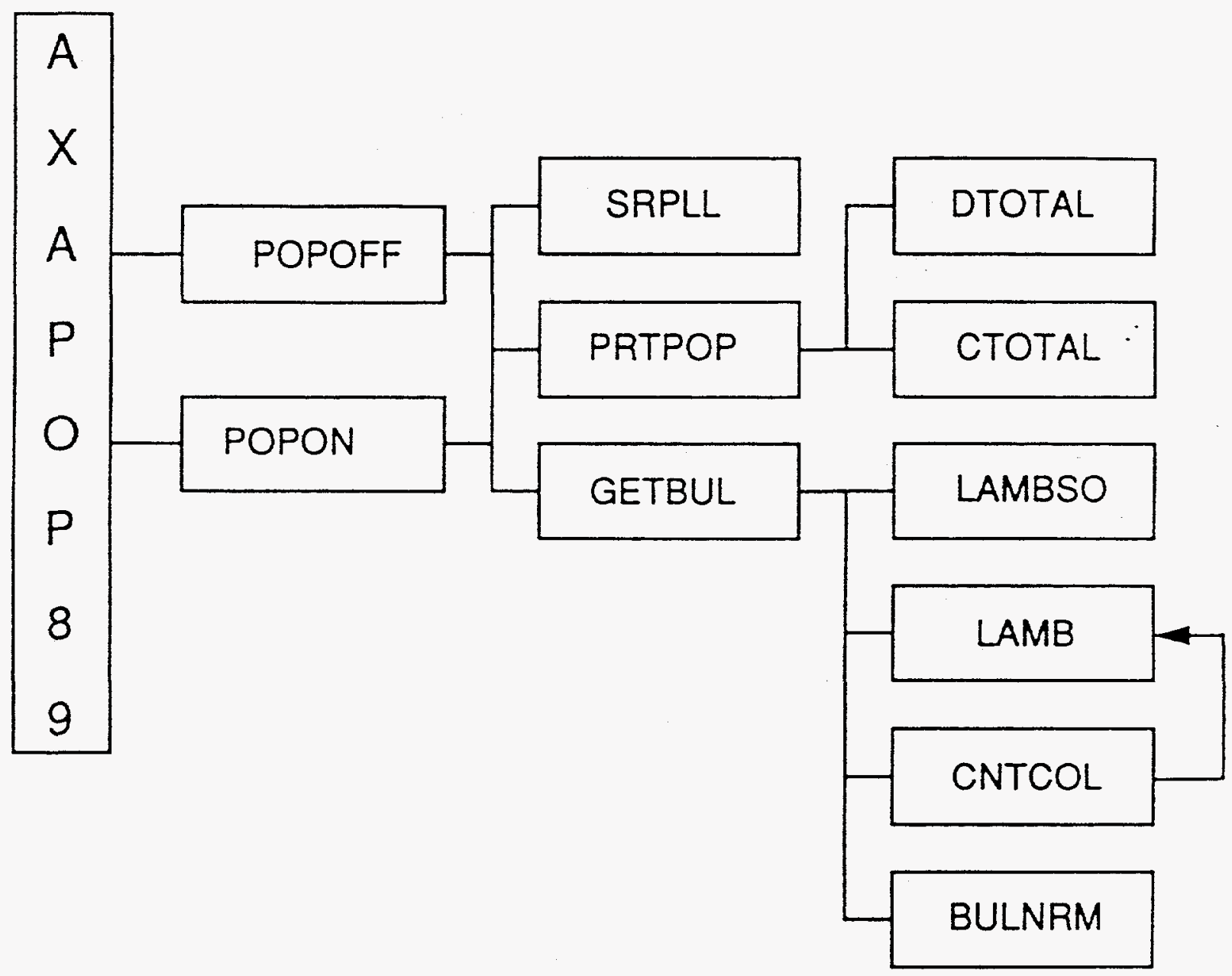


Figure 3.5. Subroutine Paths for the AXAMET89 Module

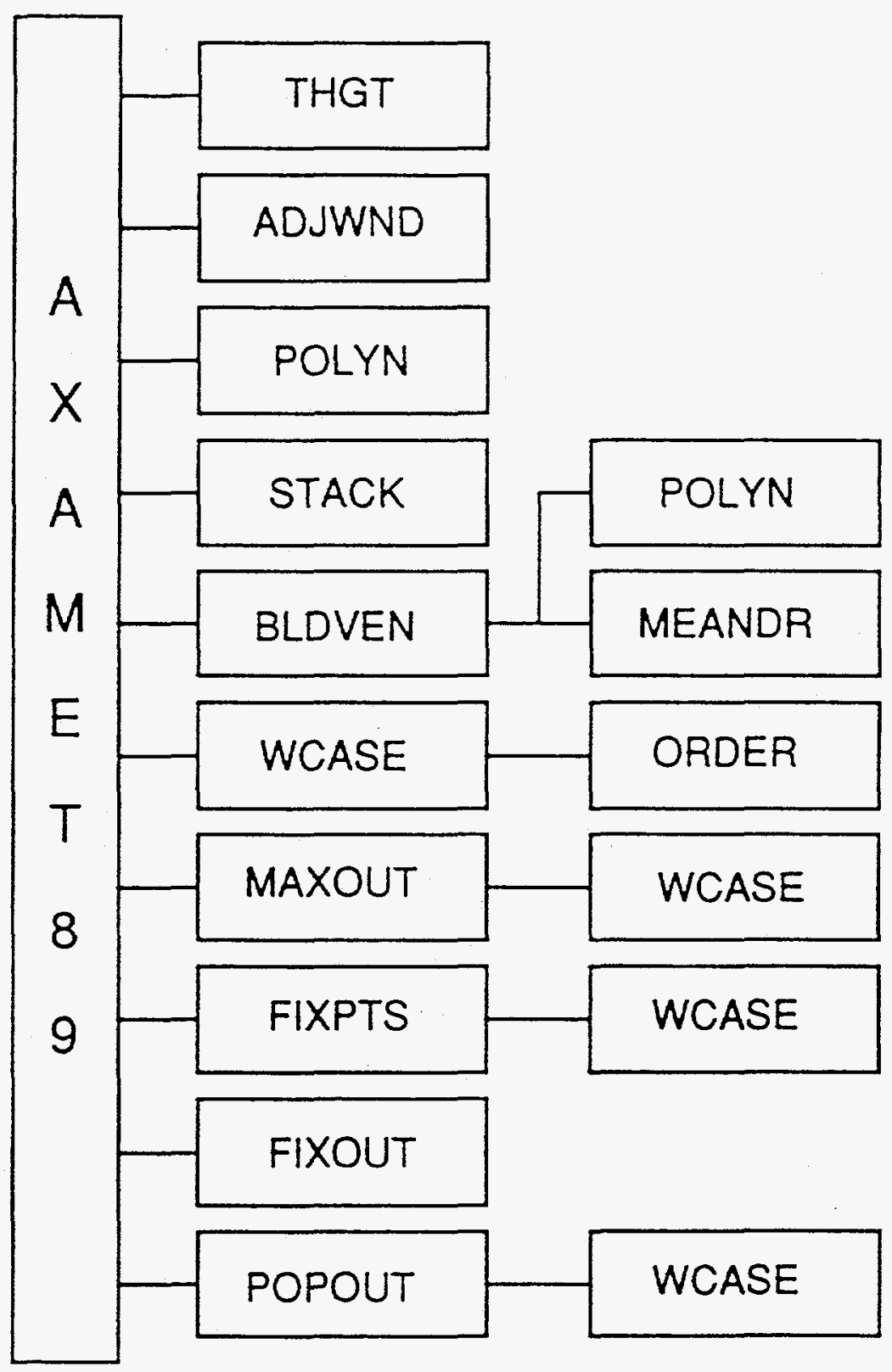


Figure 3.6. Subroutine Paths for the PRIMUSL Module

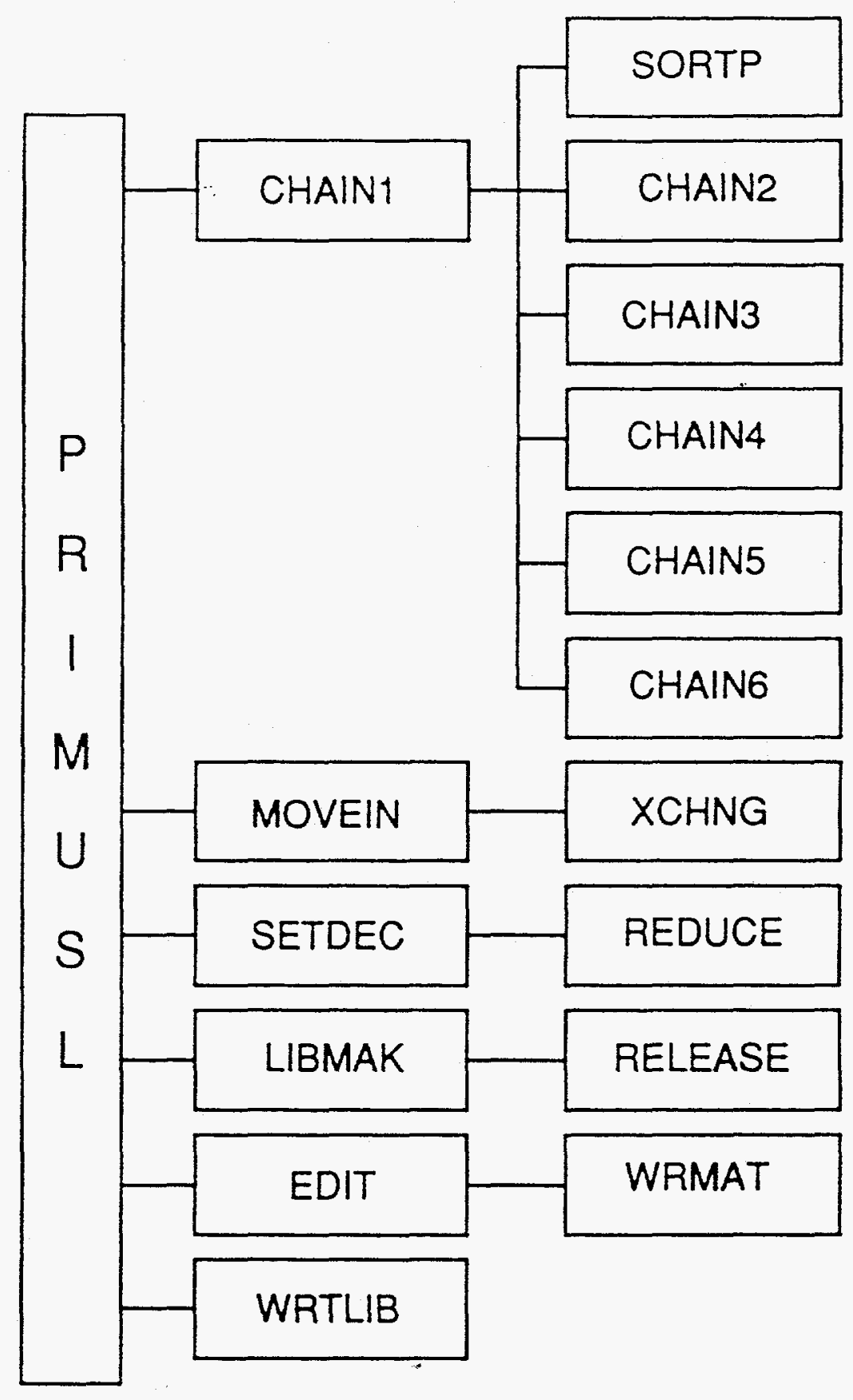


AXADOS89. The last module, AXADOS89, computes individual and population doses by radionuclide and pathway. Pathways considered in AXADOS 89 include inhalation and gamma-shine from plume immersion. Estimates can be obtained for doses that are not exceeded $50 \%$ and/or $99.5 \%$ of the time to the maximum individual at all user-specified distances and to sector populations. Sections 5 and 6 of this report describe the verification analysis of the dosimetric algorithms in AXADOS89.

Throughout this report, verifying calculations are made by hand. The hypothetical scenarios given below were used for verification of the AXAIR89Q models. Nuclides, release amounts, release height, etc. were chosen in an effort to exercise the majority of the calculational models. The AXAIR89Q application runs covering these scenarios are maintained in the Quality Assurance files of the Environmental Dosimetry Group. For simplicity, the nuclides selected below do not exercise the PRIMUSL routine. The PRIMUSL module of AXAIR89Q has been verified through separate computer runs.

$$
\begin{aligned}
\text { Release Location: } & \text { H-Area } \\
\text { Release Types: } & \text { 1) Stack (Height }=50 \text { meters) } \\
& \text { 2) Vent (Building Area }=2000 \text { sq. meters) } \\
\text { Shine Dose Methodologies: } & \text { 1) Uniform Plume Model } \\
& \text { 2) Non-uniform Plume Model } \\
& \text { 3) Upper Bound Approximation of the } \\
& \text { Non-uniform Plume Model }
\end{aligned}
$$

\begin{tabular}{ccc} 
Source Term: & Nuclides & Release (Ci) \\
\cline { 2 - 3 } & H-3 & 50,000 \\
Be-7 & 1.0 \\
C-14 & 5.0 \\
N-13 & 1.0 \\
F-18 & 1.0 \\
Mg-27 & 1.0 \\
Ar-41 & 5,000 \\
I-135 & 5.0
\end{tabular}


Figure 3.7. Subroutine Paths for the AXADOS89 Module

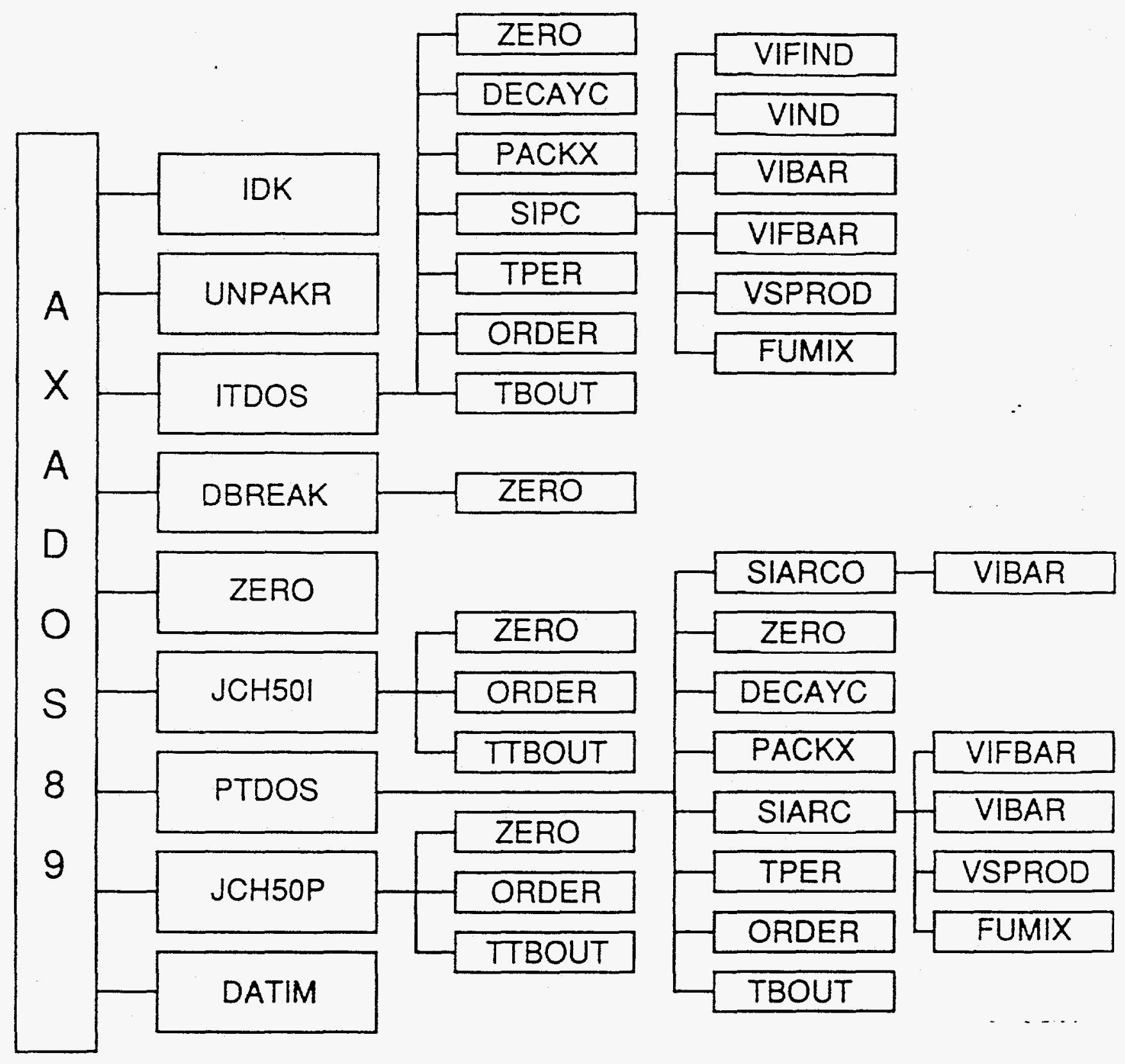




\section{ATMOSPHERIC TRANSPORT}

The atmospheric dispersion model of AXAIR89Q is contained in the AXAMET89 module. The model and its parameters are in conformance with the NRC Regulatory Guide 1.1453. A step-wise description of the methodology is given below with a complete calculation of a sample problem presented in Appendix A. Relative air concentrations $\left(X / Q^{\prime} s\right)$ determined by hand calculation have been compared to the X/Q's obtained through execution of AXAIR89Q. The results of the hand calculations appear later in this section. AXAIR89Q results of the verifying application runs are maintained as QA records by the Environmental Dosimetry Group.

\section{Meteorological Data File}

Two sets of SRS meteorological data files exist for use in the AXAMET89 routine, 1975-1979 data and 1982-1986 data. The meteorological data are obtained from hourly averages of measurements made at 1.5 second intervals. Seven data files for each of the two, five-year periods have been compiled from meteorological measurements at each onsite tower ( $A, C, D, F, H, K$, and $P$ Areas). The files contain joint frequency distributions and reciprocal average wind velocities categorized by wind direction, speed, and stability. Reciprocal average wind speeds are utilized since air concentration is inversely proportional to wind speed. Tables 4.1 and 4.2 provide wind speed and stability category definitions.

Table 4.1. Wind Speed Category Ranges

$\begin{array}{cc}\text { Speed } & \text { Range } \\ \text { Category } & (\mathrm{m} / \mathrm{sec})\end{array}$

\begin{tabular}{ll}
\hline 1 & $0-2$ \\
2 & $2-4$ \\
3 & $4-6$ \\
4 & $6-8$ \\
5 & $8-12$ \\
6 & over 12
\end{tabular}


Table 4.2. Wind Stability Categories

\begin{tabular}{cc}
$\begin{array}{c}\text { Stability } \\
\text { Category }\end{array}$ & $\begin{array}{c}\text { Std. Deviation of Wind } \\
\text { direction (degrees) }\end{array}$ \\
\hline & over 23 \\
B & $18-23$ \\
C & $13-18$ \\
D & $8-13$ \\
E & $4-8$ \\
F & $2-4$ \\
G & $0-2$
\end{tabular}

Several steps are required to convert the raw meteorological data into the formatted data used by AXAMET89. One of the most critical steps involves a quality assurance procedure that removes erroneous data, those which are outside predetermined limits or those found to lie outside the $99 \%$ confidence interval of collected data. Hand-checks have been performed on this procedure and show that it is reasonably reliable $\mathrm{s}^{45}$. Approximately $25 \%$ of the 1982.1986 observations and $33 \%$ of the 1975-1979 observations were removed from the respective data files by the quality assurance procedure. Validation of the meteorological data are the responsibility of the group from which the data originate.

See references 4 and 5 for more details on the wind statistics obtained from the SRS area meteorological towers.

\section{Terrain Data File}

Terrain elevations downwind of a stack release are necessary to calculate the effective stack height and the effective height of the inversion layer. The terrain data base accessed in the AXAMET89 module is a product of Oak Ridge National Laboratories and contains elevations above mean sea level referenced by coordinates of latitude and longitude. Terrain elevations, relative to the release point, are determined in a separate module (AXATERL) within the AXAIR89Q computer code. The AXAMET89 module reads the file generated by AXATERL containing maximum relative terrain elevations between the release point and the point of interest out to a distance of 50 miles. 
Calculation of Relative Concentration (X/Q) Values

The Gaussian plume, straight-line trajectory model is used in AXAIR89Q for estimating ground level radionuclide concentrations at given distances from a point source ${ }^{6}$. Relative concentration values are applied to all nuclides regardless of physical form, i.e., gases and particulates are not treated separately. As radioactive pollutants move downwind they are assumed to be normally distributed around the central axis of the plume with the atmospheric stability and wind speed determining its atmospheric dispersion characteristics. The standard deviations, or diffusion coefficients, in the horizontal and vertical planes relative to the plume centerline, $\sigma_{y}$ and $\sigma_{\mathrm{Z}}$, describe the spread of the plume at a given downwind distance.

\section{Determination of Horizontal and Vertical Diffusion Coefficients}

Gaseous diffusion bas been estimated by Pasquill ${ }^{7.8}$ and expressed in terms of $\sigma_{\mathrm{y}}$ and $\sigma_{z}$ for use in calculating downwind atmospheric concentrations of a given pollutant. Graphical representations of these diffusion coefficients can be found in Slade ${ }^{6}$. From these figures, algorithms have been determined to calculate $\sigma_{y}$ or $\sigma_{z}$ as functions of downwind distance for the stability categories $A$ through $F$.

The general form of the equation describing the horizontal diffusion coefficients is,

$$
\sigma_{\mathrm{y}}=\mathrm{A}\left(\mathrm{x}^{\mathrm{B}}\right)
$$

where $A$ is a scaling factor, $B$ is the slope, and $x$ is the downwind distance. Values for $A$ and $B$ applicable for distances greater than 1000 meters can be found in Reference 9 and are given in Table 4.3a. Table 4.3b shows a comparison of $\sigma_{\mathrm{y}}{ }^{\prime} \mathrm{s}$ calculated by hand compared to values obtained from the AXAMET89 subroutine determined for a specific downwind distance. The coefficients, $A$ and $B$, in equation 4.1 for distances less than 1000 meters have also been checked for accuracy with values in reference 9.

The vertical diffusion coefficients are described by the general equation,

$$
\sigma_{\mathrm{z}}=\mathrm{A}\left(\mathrm{x}^{\mathrm{B}}\right)+\mathrm{C}
$$


Table 4.3. Determination of the Horizontal Diffusion Coefficients, $\sigma_{y}$

\begin{tabular}{|c|c|c|c|c|c|}
\hline \multirow{3}{*}{ Stability } & \multirow{2}{*}{\multicolumn{2}{|c|}{ 4.3a. }} & \multicolumn{3}{|c|}{$4.3 \mathrm{~b}}$. \\
\hline & & & Stability & $\sigma_{y}(m)$ & $\sigma_{y}(m)$ \\
\hline & A & B & Category & Hand & AXAMET89 \\
\hline A & 0.3658 & 0.9031 & A & 1749 & 1749 \\
\hline B & 0.2751 & 0.9031 & B & 1316 & 1315 \\
\hline C & 0.2089 & 0.9031 & C & 999 & 998.8 \\
\hline D & 0.1471 & 0.9031 & D & 703.5 & 703.3 \\
\hline E & 0.1046 & 0.9031 & E & 500.2 & 500.1 \\
\hline $\mathrm{F}$ & 0.0722 & 0.9031 & $F$ & 345.3 & 238.3 \\
\hline & & & G & 238.4 & 238.3 \\
\hline$y_{y}(G)=\mathrm{ex}$ & $\sigma_{\mathrm{y}}=\mathrm{A}$ & & Distan & $e=118$ & 870 meters \\
\hline$\tau_{y}(G)=e^{x}$ & $0[2=\log ($ & $\left.F))-\log \left(\sigma_{y}(E)\right)\right]$ & & not lim & ited \\
\hline
\end{tabular}

where $C$ is the intercept and $A$ and $B$ are the same as in equation 4.1. Since the vertical diffusion coefficients are not represented by straight lines on the log-log plot, the curves are divided into three regions and straight-line estimates are determined for downwind distances less than 100 meters, between 100 and 1000 meters, and greater than 1000 meters. Tables $4.4 \mathrm{a}$ and $4.4 \mathrm{~b}$ present the values for A, B, \& C applicable for distances greater than 1000 meters and a comparison of hand-calculations to $\sigma_{\mathrm{z}}$ 's calculated in AXAMET89. The value of $\sigma_{\mathrm{z}}$ is limited in AXAMET89 to 160 meters, $80 \%$ of the assumed inversion height of 200 meters. The distance where $\sigma_{\mathrm{z}}$ reaches $80 \%$ of the lid height is the distance where the concentration no longer varies with distance from the earth's surface ${ }^{10}$. Diffusion coefficients for stability category $G$ are determined by an extrapolation from the $\sigma_{y}$ 's and $\sigma_{z}$ 's of stability categories $E$ and $F$.

\section{Vertical Windspeed Profile}

Measurements of wind speed at the Savannah River Site are taken at a height of 62 meters. When radioactivity is released from heights other than 62 meters, the 62 meter wind speed must be multiplied by an adjustment factor to estimate wind speed at the release height ${ }^{11}$. The adjustment factor, $F$, is a function of stability and is,

$$
F=\left(H_{e} / 62\right) C E_{i}
$$


Table 4.4. Determination of the Vertical Diffusion Coefficients, $\sigma_{z}$

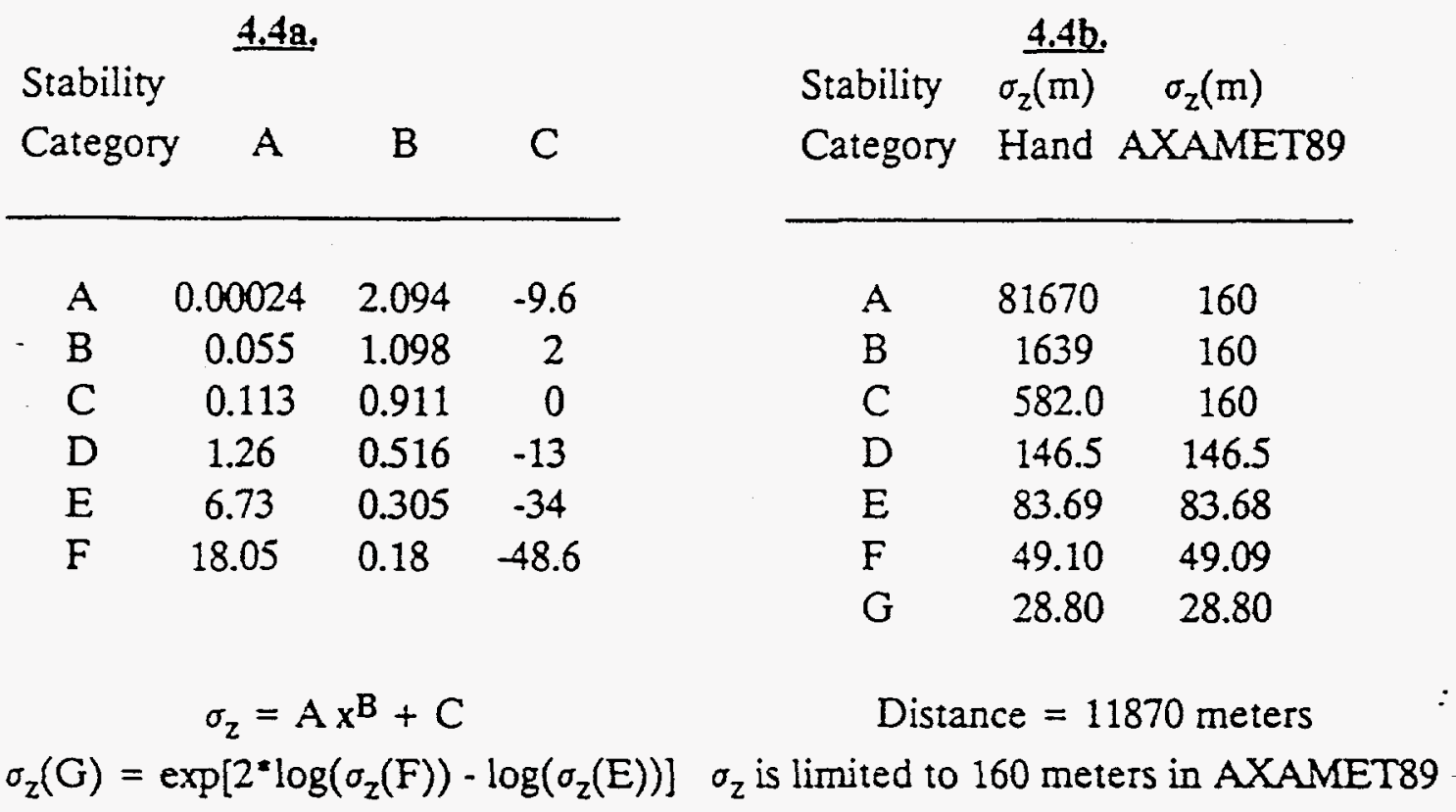

where $\mathrm{H}_{e}$ is the effective release height and $\mathrm{CE}_{\mathrm{i}}$ is the exponent of the power law for a given stability category, i. The exponents have been determined empirically at the Savannah River Site ${ }^{12}$ for all stability categories and are given in Table 4.5.

Table 4.5. Empirically Derived Power Law Exponents Describing Vertical Variation in Wind Speed at the SRS.

Stability

Category $\quad \mathrm{CE}_{\mathbf{i}}$

\begin{tabular}{cc}
\hline A & 0.08 \\
B & 0.10 \\
C & 0.11 \\
D & 0.18 \\
E & 0.31 \\
F & 0.42 \\
G & 0.42 \\
\hline
\end{tabular}




\section{Plume Depletion}

Depletion of the radioactive plume by mechanisms other than decay are not considered in AXAMET89. A separate module, PRIMUSL, handles decay and daughter ingrowth while the plume is travelling downwind. Deposition is not considered in AXAIR89Q.

\section{Relative Concentration Downwind of a Stack Release}

Radionuclides emitted from stacks that are at least 2.5 times the height of an adjacent solid structure are handled as stack releases. Otherwise, the effluent is considered to be released through a vent or other building penetration.

\section{Effective Release Height}

The physical height of the stack above grade level is referred to as the stack or release height, $\mathrm{H}_{\mathrm{s}}$. However, when determining the air concentration of the effluent at some distance from the release point, the effective release height at the receptor location must be determined. The effective release height, $\mathrm{H}_{e}$, is the height above ground level at which the central axis of the plume passes. This is given by,

$$
\mathrm{H}_{\mathrm{e}}=\mathrm{H}_{\mathrm{s}}-\mathrm{H}_{\mathrm{t}}
$$

where $H_{t}$ is the terrain height at the receptor location relative to the release point.

\section{Relative Terrain Height}

The NRC Reg. Guide $1.145^{3}$ recommends calculating $\mathrm{H}_{e}$ using the highest elevation between the release point and the downwind location to estimate a conservative radionuclide air concentration. The maximum terrain elevation relative to the elevation at the release point is determined in AXAMET89 by linear interpolation between data points in the ORNL terrain data file.

\section{Two-Hour Relative Concentration Model}

Relative concentrations at various receptor locations for a period of 2 hours following an accidental release are determined in AXAMET89 in accordance with NRC Reg. Guide $1.145^{3}$ and 10 CFR Part $100^{13}$. The meteorological conditions of fumigation and non-fumigation are considered separately. However, under certain conditions, to be explained later, the two cases are combined. 


\section{Non-Fumigation Conditions.}

In the absence of fumigation conditions (described below) a two-hour relative concentration, $\mathrm{X}_{2} / \mathrm{Q}$, is calculated using the following equation ${ }^{6}$ :

$$
\frac{X_{2}}{Q}(x, y, z)=\frac{\exp \left[-y^{2} / 2 \sigma_{y}^{2}\right]}{2 \pi \sigma_{y} \sigma_{z} U_{H S}}\left[\exp \frac{-\left(z-H_{e}\right)^{2}}{2 \sigma_{z}^{2}}+\exp \frac{-\left(z+H_{e}\right)^{2}}{2 \sigma_{z}^{2}}\right]
$$

which reduces to ${ }^{3}$,

$$
\frac{X_{2}}{Q}(x, 0,0)=\frac{\exp \left[-H_{e}^{2} / 2 \sigma_{z}^{2}\right]^{-}}{\pi \sigma_{y} \sigma_{z} U_{H S}}
$$

for centerline, ground level concentrations (i.e., $y=z=0$ ). For ground level, sectoiarc concentrations, equation 4.5 is averaged over all values of $y$ for a sector width of $22.5^{\circ}$ resulting in the following:

$$
\frac{X_{2}}{Q}(x, 0)=\frac{2.032 \exp \left[-H_{e}^{2} / 2 \sigma_{z}^{2}\right]}{U_{H S} \sigma_{z} x}
$$

It follows that the two-hour, sector-arc concentration is equal to the two-hour, centerline concentration multiplied by an averaging factor as given in the following equation:

$$
\frac{X_{2}}{Q}(x, 0)=\frac{X_{2}}{Q}(x, 0,0)\left(\frac{6.38308 \sigma_{y}}{x}\right)
$$

where the constant $(6.383)$ is equal to $(2 x)^{1 / 2}$ divided by $22.5^{\circ}$ expressed as radians. A limit is placed on the sector-arc average concentration such that it cannot exceed the centerline concentration. Sector-arc concentrations are used to estimate population doses while centerline concentrations are used to estimate maximum individual doses.

\section{Fumigation Conditions}

Conditions of fumigation exist when the downwind plume is confined between ground level and the effective inversion height with uniform vertical mixing. At the Savannah River Site fumigation is assumed to occur 1) during stable atmospheric 
conditions (stability categories E, F, or G), 2) when the wind speed at the release point, $U_{H S}$, is less than 4 meters $/ \mathrm{sec}$, and 3 ) when only out to a distance where the fumigation $X / Q$ does not exceed the non-fumigation $X / Q$ with an effective stack height of zero (i.e., where the effective inversion height is greater than $\left.\operatorname{SQRT}(\pi / 2) \sigma_{z}\right)$. When these three criteria are met, the fumigation relative concentration, $X_{2 f} / Q$, is calculated by $y^{6}$,

$$
\frac{X_{2 f}}{Q}(x, y, z)=\frac{\exp \left[-y^{2} / 2 \sigma_{y}^{2}\right]}{\sqrt{2 \pi} \sigma_{y} L_{e} U_{H S}}
$$

and reduces to $0^{3}$

$$
\frac{X_{2 f}}{Q}(x, 0,0)=\frac{1}{\sqrt{2 \pi} \sigma_{y} L_{e} U_{H S}}
$$

when $y=z=0$. The effective inversion height, $L_{e}$, is also a function of the maximum terrain height and is given by,

$$
\mathrm{L}_{\mathrm{e}}=\mathrm{L}-\mathrm{H}_{\mathrm{t}}
$$

where $\mathrm{L}$ is the inversion height relative to the release point. The two-hour, sectorarc average $X / Q$ under fumigation conditions is determined from the centerline concentration using the same averaging factor as in equation 4.8 .

Since the Savannah River Site is considered an inland site $^{3}$, a fumigation condition is considered to occur for only the first half hour of the "two-houry" period. Therefore, if the fumigation conditions are met and $X_{2 f} / Q$ exceeds $X_{2} / Q$, then $X_{2 f} / Q$ is utilized for the first half hour and $X_{2} / Q$ is utilized for the remainder of the two-hour period. This operation is accomplished by calculating a weighted sum of $X_{2 f} / Q$ (weight $=0.25$ ) and $X_{2} / Q$ (weight $=0.75$ ).

\section{Selection of $X / Q$ for Dose Evahumions}

As required by Reg. Guide 1.145 , the $X / Q$ used to calculate the worst-case dose at the site boundary will be the higher of the 99.5 th percentile, sector-specific $X / Q$ or the sector-independent 95 th percentile $\mathrm{X} / \mathrm{Q}$.

The 99.5th percentile $X / Q$ is determined on a sector-specific basis using the joint frequency distribution and an array of $42 \mathrm{X} / \mathrm{Q}$ values calculated for each of six wind 
speed categories and seven stability categories. The $42 \mathrm{X} / \mathrm{Q}^{\prime} \mathrm{s}$ are sorted in decreasing order. A "pointer" moves through the sorted array from smallest to largest $X / Q$ until the cumulative frequency of occurrence is greater than 99.5. A linear interpolation is performed between data points to determine the 99.5 percentile $X / Q$.

The 95th percentile $X / Q$, however, is not determined on a sector-specific basis. A cumulative frequency distribution is generated for the $42 \mathrm{X} / \mathrm{Qs}$ in each of 16 sectors ( $672 X / Q s)$. The 95 th percentile $X / Q$ is selected at the point where the cumulative frequency of occurrence is equal to 95.

Tests have been performed for all of the major release areas at the SRS. These tests show that, for the 1982 to 1986 meteorological data, the overall 95th percentile $\mathrm{X} / \mathrm{Q}$ is always less than the sector-specific 99.5 th percentile $X / Q$. This being the case, AXAIR89Q is programmed only to calculate and display the $95 \%$ relative concentration; worst-case doses to the maximum individual are calculated using the $99.5 \%$, sector-specific $X / Q$. If the overall $95 \% X / Q$ is larger than the worst-sector $99.5 \% \mathrm{X} / \mathrm{Q}$, the user is notified that the dose estimate methodology may be conflicting with the Reg. Guide 1.145 .

Data are included in Appendix A verifying AXAIR89Q's estimation of the 99.5th and 95 th percentile $X / Q$ s.

\section{Annual Average Relative Concentration Model}

When the release time is longer than 2 hours, an annual sector-arc average (8760hour) $\mathrm{X} / \mathrm{Q}$ is calculated for each compass sector and downwind location of interest. This then allows for the logarithmic interpolation between the two-hour $X / Q$ and the annual average $X / Q$ for approximating concentrations for intermediate release times ${ }^{3}$.

The model for annual sector-arc averaging is simply the two-hour, non-fumigation sector-arc model with the exception that the wind speed at the effective stack height, rather than the actual stack height, is used in equation 4.7.

As with $X_{2} / Q$, annual sector-arc concentrations are calculated for each of 42 meteorological conditions for a given location. The annual average concentration, $\mathrm{X}_{\mathrm{a}} / \mathrm{Q}$, is then calculated by summing the products of the $42 \mathrm{X} / \mathrm{Q}^{\prime} \mathrm{s}$ and their annual probability of occurrence ${ }^{14}$. Hand calculations of two-hour and annual average relative air concentrations are compared to AXAIR89Q estimates in Table 4.6. Distances of 1 mile, the site boundary, and 50 miles have been chosen for the comparison. The hand-calculation methodology is given in Appendix A with 
Table 4.6. Results of Hand Calculations for Two-Hour and Annual Average Relative Concentration*

STACK RELEASES

Two-Hour Concentrations

\begin{tabular}{|c|c|c|c|c|c|c|}
\hline SECTOR & $\begin{array}{c}1 \text { Mile } \\
\text { AXAIR } 890\end{array}$ & $\begin{array}{c}1 \text { Mile } \\
\text { Hand-Cale }\end{array}$ & $\begin{array}{c}\text { Boundary } \\
\text { AXAIR890 }\end{array}$ & $\begin{array}{l}\text { Boundary } \\
\text { Hand-Cale }\end{array}$ & $\begin{array}{c}50 \text { Miles } \\
\text { AXAIR89O }\end{array}$ & $\begin{array}{l}50 \text { Miles } \\
\text { Hand-Calc }\end{array}$ \\
\hline$S$ & $1.59 E-05$ & $1.59 \mathrm{E}-05$ & $1.42 \mathrm{E}-06$ & $1.42 \mathrm{E}-06$ & $2.58 \mathrm{E}-07$ & $2.58 \mathrm{E}-07$ \\
\hline SSW & $1.71 \mathrm{E}-05$ & $1.70 E-05$ & $1.97 \mathrm{E}-06$ & $1.96 \mathrm{E}-\infty 6$ & $3.84 \mathrm{E}-07$ & $3.84 \mathrm{E}-07$ \\
\hline SW & $2.70 \mathrm{E}-05$ & $2.70 E-05$ & $2.59 E-06$ & $259 \mathrm{E}-06$ & $428 E-07$ & $428 E-07$ \\
\hline WSW & $2.36 \mathrm{E}-05$ & $2.36 \mathrm{E}-05$ & $2.56 \mathrm{E}-06$ & $2.56 \mathrm{E}-06$ & $3.73 E-07$ & $3.73 E-07$ \\
\hline w & $2.00 \mathrm{E}-05$ & $2.00 \mathrm{E}-05$ & $2.42 E-06$ & $2.42 E-06$ & $3.03 E-07$ & $3.03 E-07$ \\
\hline WNW & $1.92 \mathrm{E}-05$ & $1.92 \mathrm{E}-05$ & $2.72 E-06$ & $272 E-06$ & 283E- 07 & $2.82 \mathrm{E}-07$ \\
\hline NW & $2.12 E-05$ & $2.12 E-05$ & $278 E-\infty 6$ & $2.78 \mathrm{E}-06$ & $2.89 E-07$ & $2.89 \mathrm{E}-07$ \\
\hline$N N W$ & $2.84 \mathrm{E}-05$ & $2.85 \mathrm{E}-05$ & $4.33 E-06$ & $433 E-06$ & $4.20 \mathrm{E}-07$ & $4.20 \mathrm{E}-07$ \\
\hline $\mathrm{N}$ & $2.36 \mathrm{E}-05$ & $2.36 \mathrm{E}-05$ & $2.71 E-06$ & $2.70 \mathrm{E}-06$ & $3.46 \mathrm{E}-07$ & $3.46 \mathrm{E}-07$ \\
\hline NNE & $1.36 \mathrm{E}-05$ & $1.36 \mathrm{E}-05$ & $2.68 E-06$ & $2.68 \mathrm{E}-06$ & $3.84 \mathrm{E}-07$ & $3.84 \mathrm{E}-07$ \\
\hline NE & $1.65 \mathrm{E}-05$ & $1.64 \mathrm{E}-05$ & $2.46 \mathrm{E}-06$ & $2.46 \mathrm{E}-06$ & $3.74 E-07$ & $3.74 E-07$ \\
\hline ENE & $1.59 \mathrm{E}-05$ & $1.59 E-05$ & $2.08 \mathrm{E}-06$ & $2.08 \mathrm{E}-06$ & $2.96 \mathrm{E}-07$ & $296 \mathrm{E}-07$ \\
\hline$E$ & $237 \mathrm{E}-05$ & 237E-0S & $2.12 E-06$ & $2.12 \mathrm{E}-\infty 6$ & $274 E-07$ & $274 \mathrm{E}-07$ \\
\hline ESE & $1.68 \mathrm{E}-05$ & $1.68 \mathrm{E}-05$ & $2.14 E-06$ & $2.14 \mathrm{E}-06$ & $248 E-07$ & $2.48 \mathrm{E}-07$ \\
\hline $\mathrm{SE}$. & $1.53 \mathrm{E}-05$ & $1.53 \mathrm{E}-05$ & $1.97 \mathrm{E}-06$ & $1.97 \mathrm{E}-06$ & $234 \mathrm{E}-07$ & 235E-07 \\
\hline SSE & $157 \mathrm{E}-05$ & $157 \mathrm{E}-05$ & $131 \mathrm{E}-06$ & $131 E-06$ & $206 \mathrm{E}-07$ & $2.06 E-07$ \\
\hline
\end{tabular}

STACK RELEASES

Annual Average Concentrations

\begin{tabular}{l|cc|cc|cc}
\multicolumn{1}{c|}{ SECTOR } & $\begin{array}{c}1 \text { Mile } \\
\text { AXAR89Q }\end{array}$ & $\begin{array}{c}1 \text { Mile } \\
\text { Hand-Calc }\end{array}$ & $\begin{array}{c}\text { Boundary } \\
\text { AXAIR890 }\end{array}$ & $\begin{array}{c}\text { Boundary } \\
\text { Hand-Calc }\end{array}$ & $\begin{array}{c}50 \text { Miles } \\
\text { AXAIR890 }\end{array}$ & $\begin{array}{c}50 \text { Miles } \\
\text { Hand-Calc }\end{array}$ \\
\hline S & $1.76 \mathrm{E}-07$ & $1.76 \mathrm{E}-07$ & $1.13 \mathrm{E}-08$ & $1.13 \mathrm{E}-08$ & $2.20 \mathrm{E}-09$ & $2.20 \mathrm{E}-09$ \\
SSW & $2.72 \mathrm{E}-07$ & $272 \mathrm{E}-07$ & $1.66 \mathrm{E}-08$ & $1.66 \mathrm{E}-08$ & $3.68 \mathrm{E}-09$ & $3.68 \mathrm{E}-09$ \\
SW & $4.43 \mathrm{E}-07$ & $4.43 \mathrm{E}-07$ & $3.16 \mathrm{E}-08$ & $3.16 \mathrm{E}-08$ & $6.78 \mathrm{E}-09$ & $6.78 \mathrm{E}-09$ \\
WSW & $3.54 \mathrm{E}-07$ & $3.54 \mathrm{E}-07$ & $2.91 \mathrm{E}-08$ & $2.91 \mathrm{E}-08$ & $5.44 \mathrm{E}-09$ & $5.44 \mathrm{E}-09$ \\
W & $2.65 \mathrm{E}-07$ & $2.65 \mathrm{E}-07$ & $2.60 \mathrm{E}-08$ & $2.60 \mathrm{E}-08$ & $4.11 \mathrm{E}-09$ & $4.11 \mathrm{E}-09$ \\
WNW & $2.24 \mathrm{E}-07$ & $2.24 \mathrm{E}-07$ & $2.60 \mathrm{E}-08$ & $2.60 \mathrm{E}-08$ & $3.46 \mathrm{E}-09$ & $3.46 \mathrm{E}-09$ \\
NW & $2.39 \mathrm{E}-07$ & $2.39 \mathrm{E}-07$ & $3.12 \mathrm{E}-08$ & $3.12 \mathrm{E}-08$ & $3.53 \mathrm{E}-09$ & $3.53 \mathrm{E}-09$ \\
NNW & $3.09 \mathrm{E}-07$ & $3.09 \mathrm{E}-07$ & $4.86 \mathrm{E}-08$ & $4.86 \mathrm{E}-08$ & $4.92 \mathrm{E}-09$ & $4.92 \mathrm{E}-09$ \\
N & $3.17 \mathrm{E}-07$ & $3.17 \mathrm{E}-07$ & $3.24 \mathrm{E}-08$ & $3.24 \mathrm{E}-08$ & $4.65 \mathrm{E}-09$ & $4.65 \mathrm{E}-09$ \\
NNE & $2.52 \mathrm{E}-07$ & $2.52 \mathrm{E}-07$ & $3.21 \mathrm{E}-08$ & $3.21 \mathrm{E}-08$ & $5.00 \mathrm{E}-09$ & $5.00 \mathrm{E}-09$ \\
NE & $2.88 \mathrm{E}-07$ & $2.88 \mathrm{E}-07$ & $2.98 \mathrm{E}-08$ & $2.98 \mathrm{E}-08$ & $5.20 \mathrm{E}-09$ & $5.20 \mathrm{E}-09$ \\
ENE & $3.39 \mathrm{E}-07$ & $3.39 \mathrm{E}-07$ & $2.94 \mathrm{E}-08$ & $2.94 \mathrm{E}-08$ & $5.35 \mathrm{E}-09$ & $5.35 \mathrm{E}-09$ \\
$\mathrm{E}$ & $3.53 \mathrm{E}-07$ & $3.53 \mathrm{E}-07$ & $2.86 \mathrm{E}-08$ & $2.86 \mathrm{E}-08$ & $4.10 \mathrm{E}-09$ & $4.10 \mathrm{E}-09$ \\
ESE & $3.08 \mathrm{E}-07$ & $3.08 \mathrm{E}-07$ & $2.68 \mathrm{E}-08$ & $2.68 \mathrm{E}-08$ & $3.80 \mathrm{E}-09$ & $3.80 \mathrm{E}-09$ \\
SE & $1.90 \mathrm{E}-07$ & $1.90 \mathrm{E}-07$ & $1.70 \mathrm{E}-08$ & $1.70 \mathrm{E}-08$ & $2.47 \mathrm{E}-09$ & $2.47 \mathrm{E}-09$ \\
SSE & $1.42 \mathrm{E}-07$ & $1.42 \mathrm{E}-07$ & $1.01 \mathrm{E}-08$ & $1.01 \mathrm{E}-08$ & $1.92 \mathrm{E}-09$ & $1.92 \mathrm{E}-09$ \\
\hline
\end{tabular}

- Release from 50 meter stack at E64257, N70415 (H-Area).

NOTE: Maximum X/Q for a given distance noted in BOLD. 
printouts from an electronic spreadsheet demonstrating the calculation of the twohour and annual average relative concentrations at the site boundary, in the northnorthwest sector. Examination of Table 4.6 shows that the hand-calculations are equal to the AXAIR89Q estimates (with the exception of rounding differences).

Annual average concentrations of tritium oxide measured at the SRS boundary during 1988 have been compared to annual average concentrations predicted by AXAIR89Q. Table 4.7 presents this comparison. The predicted concentrations are consistently higher than observed concentrations by at least a factor of 2.5 . The AXAIR89Q predictions were determined for a continuous release of $9.13 \times 10^{-3}$ $\mathrm{Ci} / \mathrm{sec}$ for the entire year $\left(2.88 \times 10^{5} \mathrm{Ci} / \mathrm{yr}\right)$ at a height of 62 meters from the center of the SRS while the observed concentrations are the result of numerous sources at various locations and release heights. The data in Table 4.7 are presented to show that the dispersion model used in AXAIR89Q is conservative for the estimation of annual average concentrations.

\section{Relative Concentration Downwind of a Vent Release}

As stated earlier, a radioactive gaseous effluent is assumed to be released from a building vent if the release height is less than 2.5 times the height of the adjacent solid structure.

\section{Two-hour Relative Concentration Model}

The relative air concentration on plume centerline at ground level $(y=z=0)$ for releases from building vents is determined in accordance with NRC Reg. Guide 1.1453. The three models given in the Reg. Guide are as follows:

$$
\begin{aligned}
& \frac{X_{2}}{Q}(x, 0,0)=\frac{1}{U_{10}\left(\pi \sigma_{y} \sigma_{z}+\frac{A}{2}\right)} \\
& \frac{X_{2}}{Q}(x, 0,0)=\frac{1}{U_{10}\left(3 \pi \sigma_{y} \sigma_{z}\right)} \\
& \frac{X_{2}}{Q}(x, 0,0)=\frac{1}{U_{10}\left(\pi \Sigma_{y} \sigma_{z}\right)}
\end{aligned}
$$


where $U_{10}$ is the 10 -meter wind speed, $A$ is the minimum vertical cross-sectional area of the adjacent building, and $\Sigma_{\mathrm{y}}$ is the lateral plume spread with meander and building wake corrections. The corrected lateral plume spread, $\Sigma_{\mathrm{y}}$, is determined as follows,

$$
\Sigma_{y}=\left\{\begin{array}{cl}
\sigma_{y}+(M-1) \sigma_{y(800)} & \text { for } x>800 \text { meters } \\
\sigma_{y} M & \text { for } x \leq 800 \text { meters }
\end{array}\right.
$$

where plume meander, $M$, is a function of the wind speed and stability at 10 meters.

Table 4.7. Comparison of Observed to Predicted Tritium Oxide Concentrations in Air at the SRS Boundary.

Location Sector/Distance Observed(a) Predicted(b) Pred/Obs

$\begin{array}{ccccc}\text { Jackson } & 10.7 \mathrm{mi} \mathrm{WNW} & 47(74) & 118 & 2.5 \\ \text { Pattersons Mill } & 10.3 \mathrm{mi} \mathrm{SE} & 33(35) & 101 & 3.1 \\ \text { Talatha } & 10.3 \mathrm{mi} \mathrm{NNW} & 86(160) & 240 & 2.8 \\ \text { W. Jackson } & 8.4 \mathrm{mi} \mathrm{W} & 50(69) & 163 & 3.3 \\ \text { Windsor Rd. } & 11.4 \mathrm{mi} \mathrm{NNE} & 58(96) & 173 & 3.0 \\ \text { Darkhorse } & 11.2 \mathrm{mi} \mathrm{NE} & 50(64) & 168 & 3.4 \\ \text { E. Talatha } & 10.5 \mathrm{mi} \mathrm{N} & 51(79) & 171 & 3.4 \\ \text { Greenpond } & 9.5 \mathrm{mi} \mathrm{NW} & 64(95) & 160 & 2.5 \\ \text { Hiway 21/167 } & 9.9 \mathrm{mi} \mathrm{ENE} & 42(53) & 195 & 4.6 \\ \text { Allendale Gate } & 9.1 \mathrm{mi} \mathrm{SSE} & 24(17) & 88 & 3.7 \\ \text { A-14 } & 5.5 \mathrm{mi} \mathrm{SSW} & 65(94) & 265 & 4.1 \\ \text { Barnwell Gate } & 9.3 \mathrm{mi} \mathrm{E} & 45(56) & 206 & 4.6 \\ \text { D-Area } & 8.2 \mathrm{mi} \mathrm{WSW} & 90(89) & 220 & 2.4\end{array}$

(a) values taken from the 1988 Environmental Report, WSRC-RP-89-59-1, Vol. 2; numbers in parentheses are $1 \sigma$ std. deviations attributable to counting error.

(b) annual average concentrations determined from AXAIR890 X/Qs calculated for a hypothetical release of $2.88 \times 10^{5} \mathrm{Ci} / \mathrm{yr}$ tritium oxide at 62 meters from the geographical center of the Site.

Horizontal plume meander is to be considered during neutral or stable atmospheric conditions (stability categories D, E, F, or G) and when the wind speed at the 10meter level is less than $6 \mathrm{~m} / \mathrm{sec}^{3}$. When the conditions do not exist for the inclusion of plume meander; the appropriate $X_{2} / Q$ is the larger value calculated in Equations 
4.1 and 4.2. However, when plume meander is considered, the appropriate $X_{2} / Q$ is the smaller value of Equation 4.3 and the $X_{2} / Q$ without considering plume meander.

The two-hour, sector-arc concentration is determined using the same averaging factor as in equation 4.8 after the operations described above are performed. The 99.5 th percentile $X_{2} / Q$ is determined in the same manner as for stack releases.

Two-hour and annual average relative concentrations determined by handcalculations and by AXAIR89Q are given in Table 4.8 at various downwind distance following a vent release. As in Table 4.6, the hand-calculations are essentially equal to the AXAIR89Q estimates. Several additional comparisons have been performed between hand-calculations and AXAIR89Q relative concentrations for various release scenarios, downwind distances, sectors, etc. These comparisons are presented in Table 4.9. The overall 95th percentile X/Q calculated by hand for the scenario given in Section 2 was different from that calculated through AXAIR89Q by less than $0.5 \%$.

\section{Anrual Average Relative Concentration Model}

The annual average $X / Q$ for vent releases is determined by the same method as that for stack releases except that the effective stack height, $\mathrm{H}_{e}$, is set equal to zero and the wind speed is that at the 10-meter level. Averaging air concentrations over 8760 hours masks any effects from plume meander and building wake found in a vent release.

\section{Decay Products at Receptor Lacations}

As stated in Section 3, the PRIMUSL routine generates the decay chains for the nuclides in the source term. Several PRIMUSL generated decay chains have been examined for accuracy. The thorium, neptunium, uranium, and actinium decay series were also generated correctly by PRIMUSL. Those daughters with branching ratios less than approximately $0.1 \%$ are not included in the chains. Concentrations of each daughter at the receptor are calculated in the AXADOS89 routine. 
Table 4.8. Results of Hand Calculations for Two-Hour and Annual Average Relative Concentration

VENT RELEASE

Two-Hour Concentrations

\begin{tabular}{|c|c|c|c|c|c|c|}
\hline SECTOR & $\begin{array}{c}1 \text { Mile } \\
\text { AXAIR89Q }\end{array}$ & $\begin{array}{c}1 \text { Mile } \\
\text { Hand-Calc }\end{array}$ & $\begin{array}{c}\text { Boundary } \\
\text { AXAIR89Q }\end{array}$ & $\begin{array}{l}\text { Boundary } \\
\text { Hand-Calc }\end{array}$ & $\begin{array}{l}50 \text { Miles } \\
\text { AXAIR89Q }\end{array}$ & $\begin{array}{l}50 \text { Miles } \\
\text { Hand-Calc }\end{array}$ \\
\hline$S$ & $3.66 \mathrm{E}-05$ & $3.66 \mathrm{E}-05$ & $2.41 E-06$ & $2.41 \mathrm{E}-06$ & $4.18 E-07$ & $4.18 \mathrm{E}-07$ \\
\hline SSW & $5.52 E-05$ & 5.52E-05 & $4.21 E-\infty 6$ & $4.21 E-06$ & $7.40 \mathrm{E}-07$ & $7.39 E-07$ \\
\hline SW & $5.77 E-05$ & $5.78 E-05$ & $5.70 E-06$ & $5.71 E-06$ & 8.10E-07 & $8.10 \mathrm{E}-07$ \\
\hline WSW & 5.51E-05 & S.51E-05 & 4.89E-06 & $4.89 E-06$ & $7.06 \mathrm{E}-07$ & 7.07E-07 \\
\hline$w$ & $4.94 E-05$ & $4.94 E-05$ & $3.23 E-06$ & $3.23 E-06$ & 4.21E-07 & 4.21E-07 \\
\hline WNW & $4.62 E-05$ & 4.62E-05 & $4.59 E-06$ & $4.59 E-06$ & $3.94 E-07$ & $3.94 \mathrm{E}-07$ \\
\hline$N W$ & $3.98 \mathrm{E}-05$ & $3.98 \mathrm{E}-0.5$ & 4.51E-06 & $4.51 E-06$ & $3.88 E-07$ & $3.88 \mathrm{E}-07$ \\
\hline NNW & $5.65 \mathrm{E}-05$ & $5.66 \mathrm{E}-05$ & $7.02 E-06$ & $7.02 \mathrm{E}-06$ & $8.02 \mathrm{E}-07$ & 8.03E-07 \\
\hline $\mathrm{N}$ & $4.82 \mathrm{E}-05$ & $4.82 E-05$ & 5.45E-06 & $5.45 E-06$ & $5.45 \mathrm{E}-07$ & $5.45 E-07$ \\
\hline NNE & $5.39 E-05$ & $5.39 E-05$ & $3.91 E-06$ & $3.91 E-06$ & $6.36 E-07$ & $636 \mathrm{E}-07$ \\
\hline NE & $5.43 E-05$ & $5.43 E-05$ & $3.72 E-\infty 6$ & $3.72 E-06$ & $6.37 \mathrm{E}-07$ & $637 \mathrm{E}-07$ \\
\hline ENE & $4.56 \mathrm{E}-05$ & $4.56 E-05$ & $4.19 E-06$ & 4.19E-06 & $5.49 E-07$ & $5.49 E-07$ \\
\hline$E$ & $4.63 E-05$ & $4.64 \mathrm{E}-05$ & $3.27 E-06$ & 3.27E-06 & $3.84 E-07$ & $3.84 \mathrm{E}-07$ \\
\hline ESE & 3.69E-0S & $3.69 E-05$ & $3.06 \mathrm{E}-06$ & $3.06 E-06$ & 4.09E-07 & $4.10 \mathrm{E}-07$ \\
\hline$S E$ & $3.37 \mathrm{E}-05$ & $3.37 \mathrm{E}-05$ & $2.89 E-06$ & $2.89 \mathrm{E}-06$ & $331 \mathrm{E}-07$ & $330 \mathrm{E}-07$ \\
\hline SSE & $3.27 \mathrm{E}-05$ & $3.26 \mathrm{E}-05$ & $1.92 E-06$ & $1.92 \mathrm{E}-06$ & $2.82 \mathrm{E}-07$ & $282 E-07$ \\
\hline
\end{tabular}

VENT RELEASE

Annual Average Concentrations

\begin{tabular}{l|cc|cc|cc}
\multicolumn{1}{c|}{ SECTOR } & $\begin{array}{c}1 \text { Mile } \\
\text { AXAIR890 }\end{array}$ & $\begin{array}{c}1 \text { Mile } \\
\text { Hand-Calc }\end{array}$ & $\begin{array}{c}\text { Boundary } \\
\text { AXAIR8 } 90\end{array}$ & $\begin{array}{c}\text { Boundary } \\
\text { Hand-Calc }\end{array}$ & $\begin{array}{c}50 \text { Miles } \\
\text { AXAIR890 }\end{array}$ & $\begin{array}{c}50 \text { Miles } \\
\text { Hand-Calc }\end{array}$ \\
\hline S & $3.98 E-07$ & $3.98 E-07$ & $1.56 \mathrm{E}-08$ & $1.56 \mathrm{E}-08$ & $2.87 \mathrm{E}-09$ & $2.87 \mathrm{E}-09$ \\
SSW & $6.49 \mathrm{E}-07$ & $6.49 \mathrm{E}-07$ & $2.37 \mathrm{E}-08$ & $2.37 \mathrm{E}-08$ & $4.33 \mathrm{E}-09$ & $4.33 \mathrm{E}-09$ \\
SW & $1.05 \mathrm{E}-06$ & $1.05 \mathrm{E}-06$ & $4.62 \mathrm{E}-08$ & $4.62 \mathrm{E}-08$ & $6.79 \mathrm{E}-09$ & $6.79 \mathrm{E}-09$ \\
WSW & $7.88 \mathrm{E}-07$ & $7.88 \mathrm{E}-07$ & $4.10 \mathrm{E}-08$ & $4.10 \mathrm{E}-08$ & $5.44 \mathrm{E}-09$ & $5.44 \mathrm{E}-09$ \\
W & $6.03 \mathrm{E}-07$ & $6.03 \mathrm{E}-07$ & $3.14 \mathrm{E}-08$ & $3.14 \mathrm{E}-08$ & $4.11 \mathrm{E}-09$ & $4.11 \mathrm{E}-09$ \\
WNW & $5.22 \mathrm{E}-07$ & $5.2 \mathrm{EE}-07$ & $2.93 \mathrm{E}-08$ & $2.93 \mathrm{E}-08$ & $3.46 \mathrm{E}-09$ & $3.46 \mathrm{E}-09$ \\
NW & $5.68 \mathrm{E}-07$ & $5.68 \mathrm{E}-07$ & $3.13 \mathrm{E}-08$ & $3.13 \mathrm{E}-08$ & $3.53 \mathrm{E}-09$ & $3.53 \mathrm{E}-09$ \\
NNW & $8.86 \mathrm{E}-07$ & $8.86 \mathrm{E}-07$ & $4.87 \mathrm{E}-08$ & $4.87 \mathrm{E}-08$ & $4.92 \mathrm{E}-09$ & $4.92 \mathrm{E}-09$ \\
N & $7.70 \mathrm{E}-07$ & $7.70 \mathrm{E}-07$ & $4.31 \mathrm{E}-08$ & $4.31 \mathrm{E}-08$ & $4.65 \mathrm{E}-09$ & $4.65 \mathrm{E}-09-$ \\
NNE & $7.83 \mathrm{E}-07$ & $7.83 \mathrm{E}-07$ & $4.14 \mathrm{E}-08$ & $4.14 \mathrm{E}-08$ & $5.00 \mathrm{E}-09$ & $5.00 \mathrm{E}-09$ \\
NE & $7.72 \mathrm{E}-07$ & $7.72 \mathrm{E}-07$ & $3.94 \mathrm{E}-08$ & $3.94 \mathrm{E}-08$ & $5.20 \mathrm{E}-09$ & $5.20 \mathrm{E}-09$ \\
ENE & $7.18 \mathrm{E}-07$ & $7.18 \mathrm{E}-07$ & $3.76 \mathrm{E}-08$ & $3.76 \mathrm{E}-08$ & $5.36 \mathrm{E}-09$ & $5.36 \mathrm{E}-09$ \\
E & $7.23 \mathrm{E}-07$ & $7.23 \mathrm{E}-07$ & $3.88 \mathrm{E}-08$ & $3.89 \mathrm{E}-08$ & $5.26 \mathrm{E}-09$ & $5.26 \mathrm{E}-09$ \\
ESE & $6.12 \mathrm{E}-07$ & $6.12 \mathrm{E}-07$ & $3.24 \mathrm{E}-08$ & $3.25 \mathrm{E}-08$ & $4.46 \mathrm{E}-09$ & $4.46 \mathrm{E}-09$ \\
SE & $3.87 \mathrm{E}-07$ & $3.87 \mathrm{E}-07$ & $2.06 \mathrm{E}-08$ & $2.06 \mathrm{E}-08$ & $2.89 \mathrm{E}-09$ & $2.89 \mathrm{E}-09$ \\
SSE & $3.02 \mathrm{E}-07$ & $3.02 \mathrm{E}-07$ & $1.24 \mathrm{E}-08$ & $1.24 \mathrm{E}-08$ & $2.28 \mathrm{E}-09$ & $2.28 \mathrm{E}-09$ \\
\hline
\end{tabular}

- Release from building vent at E64257, N70415 (H-Area); building area equal to 2000 sq. meters.

NOTE: Maximum X/Q for a given distance noted in BOLD. 
Table 4.9. Results of Hand Calculations for Two-Hour Centerline, Two-Hour

Sector-Are and Sector-Arc Annual Average Relative Concentration*

\section{STACK RELEASE*}

\begin{tabular}{|c|c|c|c|c|c|c|}
\hline Lacation & $\begin{array}{l}\text { 2-Hour Catr } \\
\text { AXAIR } 890\end{array}$ & $\begin{array}{l}\text { 2-Hour Catr } \\
\text { Hand-Calc }\end{array}$ & $\begin{array}{l}\text { 2-Hour Arc } \\
\text { AXAIR89Q }\end{array}$ & $\begin{array}{l}\text { 2-Hour Arc } \\
\text { Hand-Calc }\end{array}$ & $\begin{array}{l}\text { Ann. Avg. } \\
\text { AXAIR89Q }\end{array}$ & $\begin{array}{l}\text { Ann. Avg. } \\
\text { Hand-Calc }\end{array}$ \\
\hline $\mathrm{S} ; 80450 \mathrm{~m}$ & $2.58 \mathrm{E}-07$ & $2.58 \mathrm{E}-07$ & $1.02 E-07$ & $1.02 E-07$ & $2.20 \mathrm{E}-09$ & $2.20 \mathrm{E}-09$ \\
\hline SW; $1609 \mathrm{~m}$ & $2.70 E-05$ & $2.70 \mathrm{E}-05$ & $7.85 E-06$ & $7.85 E-06$ & 4.43E-07 & 4.43E-07 \\
\hline WNW; $6440 \mathrm{~m}$ & $4.94 E-06$ & $4.94 \mathrm{E}-06$ & $1.43 E-06$ & $1.42 E-06$ & $4.52 E-08$ & $4.52 \mathrm{E}-08$ \\
\hline $\mathrm{NE} ; 32180 \mathrm{~m}$ & $1.06 E-06$ & $1.06 E-06$ & $3.03 E-07$ & $3.03 E-07$ & $1.42 E-08$ & $1.42 \mathrm{E}-08$ \\
\hline $\mathrm{SE} ; 3220 \mathrm{~m}$ & $1.14 E-05$ & $1.14 E-05$ & $292 E-06$ & 2.91E.06 & $9.09 E-08$ & $9.09 E-08$ \\
\hline
\end{tabular}

\section{VENT RELEASE**}

\begin{tabular}{|c|c|c|c|c|c|c|}
\hline Location & $\begin{array}{l}\text { 2-Hour Catr } \\
\text { AXAIR89Q }\end{array}$ & $\begin{array}{l}\text { 2-Hour Cntr } \\
\text { Hand-Cale }\end{array}$ & $\begin{array}{l}\text { 2-Hour Are } \\
\text { AXAIR89Q }\end{array}$ & $\begin{array}{l}\text { 2-Hour Are } \\
\text { Hand-Calc }\end{array}$ & $\begin{array}{l}\text { Ann. Avg. } \\
\text { AXAIR890 }\end{array}$ & $\begin{array}{l}\text { Ann. Avg. } \\
\text { Hand-Calo }\end{array}$ \\
\hline$S W ; 6+140 \mathrm{~m}$ & $1.40 \mathrm{E}-05$ & $1.40 \mathrm{E}-05$ & $2.86 \mathrm{E}-06$ & $2.85 \mathrm{E}-06$ & $136 \mathrm{E}-07$ & $136 \mathrm{E}-07$ \\
\hline WNW; $80450 \mathrm{~m}$ & $3.94 E-07$ & $3.94 \mathrm{E}-07$ & $1.23 E-07$ & $1.23 E-07$ & 3.46E-09 & $3.46 \mathrm{E}-09$ \\
\hline $\mathrm{N} ; 32180 \mathrm{~m}$ & $1.70 E-06$ & $1.70 \mathrm{E}-06$ & $3.76 E-07$ & $3.76 \mathrm{E}-07$ & $1.29 E-08$ & $1.29 \mathrm{E}-08$ \\
\hline $\mathrm{NE} ; 1609 \mathrm{~m}$ & $5.43 E-05$ & $5.43 \mathrm{E}-0.5$ & $1.24 E-05$ & $1.24 \mathrm{E}-05$ & $7.72 E-07$ & $7.72 E-07$ \\
\hline$S E ; 6-1360 \mathrm{~m}$ & $4.04 E-07$ & $4.04 \mathrm{E}-07$ & 1.72E-07 & 1.72E-07 & $3.62 \mathrm{E}-09$ & $3.62 E-09$ \\
\hline
\end{tabular}

- Release from 50 meter stack at E64257, N70415 (H-Area).

-* Release from building vent at E64257, N70415 (H-Area); building cross sectional area assumed to be 2000 sq. meters. 


\section{INTERNAL DOSIMETRY}

AXADOS89, the dosimetry module of AXAIR89Q, was designed to estimate individual and population doses due to the unplanned release of radioactive materials. Since the duration times of these unplanned releases are assumed to be relatively short (on the order of several hours), the dose estimates considered in AXADOS89 include those pathways responsible for one's "instantaneous dose", i.e., inhalation and plume-shine. The ingestion and ground-shine pathways are not considered since, in the case of an actual acute release with high contamination levels, DOE would initiate its interdiction plan to remove the contaminated food source and remove populations from contaminated land.

Ingrowth of daughter products is simulated in AXADOS89 by estimating daughter concentrations at the receptor from parent concentrations at the same location. The parent nuclide decays for a time equal to the transport time. During transport, the daughter also decays. Doses to exposed individuals from daughter products estimated by AXAIR 89 Q have been reproduced by hand-calculation (see Appendix B page B16). The hand-calculated estimates are within $10 \%$ of the AXAIR89Q estimates for the dose-dominant nuclides. This difference is considered acceptable since actual transport times are difficult to reproduce without the aid of the mainframe computer.

\section{ESTIMATION OF INHALATION DOSE}

Generally, inhalation dose is estimated by the product of the radionuclide concentration in the air that is breathed, the rate at which the air is breathed, and a factor to convert intake quantities to dose. The radionuclide concentration is determined by estimating the concentration at a given downwind distance relative to the radionuclide release rate (see Section 4). The inhalation dose to a given individual or population, assuming exposure during the entire plume passage, is calculated in AXADOS89 using the following general equation,

$$
D=3.17 \times 10^{-8}(Q)(X / Q)(D F)(B) e^{-\lambda t}
$$

where $3.17 \times 10^{-8}=$ conversion factor, years per second;

$Q=$ total release, in curies;

$\mathrm{X} / \mathrm{Q}=$ relative concentration at receptor, sec per $\mathrm{m}^{3} ;$

$\mathrm{DF}=$ effective dose equivalent dose factor for inhalation, rem per curie intake;

$B=$ breathing rate, $\mathrm{m}^{3}$ per year;

$\lambda=$ decay constant, $\sec ^{-1}$;

$t=$ travel time from release to receptor, sec. 
The exponential factor in equation 5.1 provides for the decay of radionuclides during the time between release from the facility and uptake by the receptor.

Two dose factor data bases can be accessed by AXADOS89 including, 1) the ICRP2 dose factor library ${ }^{15}$, and 2) the ICRP30 dose factor library ${ }^{16}$. The Department of Energy mandates the use of ICRP30 dose factors in all DOE sponsored dose assessments ${ }^{17}$. The option to use ICRP2 dose factors is included in AXADOS89 to enable the user to reconstruct previously determined dose estimates which originally used the ICRP2 factors. In this report, only dose estimates derived using ICRP30 dose factors will be checked by hand calculation.

ICRP30 dose factors for inhalation are taken from reference 17 and are provided for the dose estimate of committed effective dose equivalent (CEDE) and to the following organs: red bone marrow, liver, bone surface, thyroid, lower large intestine, and lungs. By selecting the proper dose factor, equation 5.1 can be used to estimate organ doses or the CEDE. The procedure for generating the ICRP30 inhalation dose factor library was to use the lung-clearance-class-specific dose factors that resulted in the highest CEDE. See Reference 18 for more on the implications of this procedure.

\section{Selection of the 99.5th and 50th Percentile Doses}

Like the calculations of 99.5 th percentile relative concentration, the AXADOS89 dose calculations are performed for every combination of wind speed and stability for each sector. The whole array of doses are determined since the amount of radioactive decay is dependent upon the transit time from release to receptor (i.e., wind speed). The relative concentration used in equation 5.1 is that which is calculated for each combination of wind speed and stability. Once all of the doses are calculated, the method of choosing the 99.5 th percentile dose is identical to the method in Section 4 of choosing the 99.5 th percentile relative air concentration.

A 50th percentile dose will be calculated and presented if specified by the user. This sector-independent dose estimate is determined by calculating the individual or population dose for all 672 meteorological combinations and selecting the 50th percentile dose from the cumulative probability distribution.

\section{Verification of the Inhalation Model}

Several nuclides were selected to verify the inhalation model. Hand calculations of the CEDE to a maximum individual resulting from the inhalation of a given concentration of each nuclide were performed and compared to the results from 
AXAIR89Q. Table 5.1 shows this comparison. The dose estimates are made based on the assumption that the maximum individual's breathing rate is $12,000 \mathrm{~m}^{3} / \mathrm{yr}^{19}$.

The nuclide concentrations used in equation 5.1 were derived by the methodology of Section 4. Dose estimates were then determined for each of the 42 meteorological conditions. A linear interpolation was performed between the speed and stability classes determined to give the 99.5 th percentile relative concentration. For example, in Section 4 it was determined that the interpolation was to be performed between speed/stability classes $6-2$ and $6-3$ with an interpolation factor of -0.0841 (see page A11). This same interpolation is performed on the dose calculations using the $X / Q$ s and wind speeds associated with speed/stability classes 6-2 and 6-3. The calculations for the dose estimates provided in Table 5.1 are presented in Appendix $B$ on pages $B 1$ through $B 5$.

Table 5.1. Comparison of Inhalation Dose*: AXAIR89Q to Hand-Calculations

\begin{tabular}{|c|c|c|}
\hline & $\begin{array}{l}\text { AXAIR89Q } \\
\text { Dose (mrem) }\end{array}$ & $\begin{array}{l}\text { Hand-Calculation } \\
\text { Dose (mrem) }\end{array}$ \\
\hline
\end{tabular}

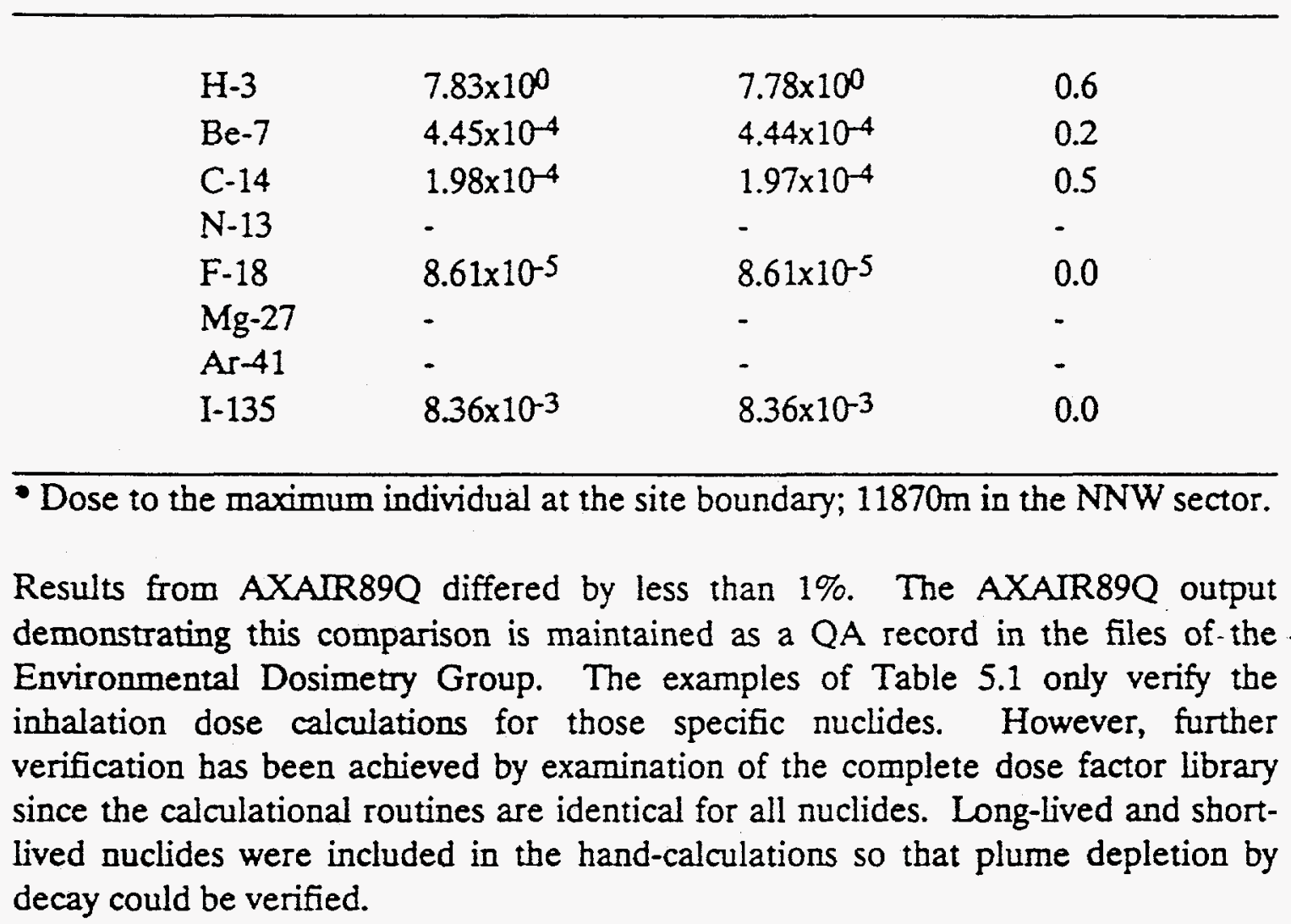


The population inhalation dose is obtained in the same manner as the maximum individual dose with the following exceptions: 1) the adult breathing rate is 10,500 $\mathrm{m}^{3} / \mathrm{yr}^{19} ; 2$ ) the 50 -mile population is subdivided into annular groups with the following inner and outer radii, 0-1, 1-2, 2-3, 3-4, 4-5, 5-10, 10-20, 20-30, 30-40, and 40-50 miles; and 3) the population within a given annulus is exposed to the same nuclide concentration regardless of location within the annulus. This concentration is equal to the sector-arc concentration at the midpoint of the annulus. The population dose is then the sum, over all annuli, of the product of the population in a given annulus by the "average" dose in that annulus. ICRP30 dose factors do not exist for age groups other than adults, however, the population-weighed breathing rate takes into account the distribution of adults, teens, and children. The population dose calculated by the ICRP30 methodology, therefore, takes credit for the age distribution of the population but not for age-specific dose factors. The calculation of the population inhalation dose to a single sector exposed to a release of tritium oxide is presented in Figure 5.1.

The difference shown between the AXAIR89Q and hand-calculated population dose can be attributed to rounding error. The supporting calculations of relative concentration and the interpolations performed thereon can be found on pages B6 through B15 in Appendix B.

\section{EXTERNAL DOSIMETRY}

External dose from gamma irradiation is estimated in AXAIR89Q by one of three methods: 1) the uniform plume model, 2) the non-uniform plume model, or 3) an upper-bound approximation of the non-uniform plume model. Shine doses are independent of age and body organ.

Shine doses, like inhalation doses, are determined for all 42 meteorological conditions in a given compass sector at a given downwind distance. The two-hour 99.5th percentile doses are determined from an array of total dose values (i.e., shine plus inhalation) in each of the 16 compass sectors. These doses are then compared to find the sector with the largest 99.5 th percentile dose. The two-hour 50th percentile dose is also selected from an array of total dose values but it is not sectorspecific. Doses determined for all 16 sectors and all 42 meteorological observations are grouped when selected the 50th percentile dose.

\section{UNIFORM PLUME MODEL}

The uniform plume model assumes that the exposed individual is located in a timeintegrated uniform concentration of a given nuclide throughout the infinite 
Figure 5.1 Offsite Population Dose Calculation Inhalation of Tritium Oxide

Release Amount $=5.0 \times 10^{4} \mathrm{Ci}$ Tritium Oxide (in 2 hour period)

Release Type: 50 Meter Stack from H-Area (E64257;N70415)

Max. Population Sector: WNW (77.3\% Adult/Teen, 22.7\% Child)

Dose to a given individual, $\mathrm{D}(\mathrm{ind})_{\mathrm{jk}}$ :

$$
\begin{aligned}
& \mathrm{D}(\mathrm{ind})_{\mathrm{jk}}=3.17 \times 10^{-8}(\mathrm{Q})\left(\mathrm{X} / \mathrm{Q}_{\mathrm{k}}\right)(\mathrm{DF})\left(\mathrm{B}_{\mathrm{j}}\right) \mathrm{e}^{-\lambda t} \\
& \text { where } 3.17 \times 10^{-8}=\text { conversion factor, years per second, } \\
& \mathrm{Q}=\text { total release, curies; } \\
& \mathrm{X} / \mathrm{Q}_{\mathrm{K}}=\text { sector-arc relative concentration at } \mathrm{k}^{\text {th }} \text { receptor distance, } \\
& \mathrm{sec} / \mathrm{m}^{3} \text {, (receptor distance is the center of the population. } \\
& \text { region); } \\
& \mathrm{DF}=9.45 \times 10^{4} \mathrm{mrem} / \mathrm{Ci} \text {, tritium dose factor (cede) for inhalation }
\end{aligned}
$$

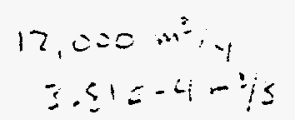

$$
\begin{aligned}
& \mathrm{B}_{\mathrm{j}}=\text { breathing rate for } \mathrm{j}^{\mathrm{th}} \text { age group, Adult } / \text { Teen } 10,500 \mathrm{~m}^{3} / \mathrm{yr} \text {, } \\
& \lambda=\text { tritium decay constant, } 1.8 \times 10^{-9} \sec ^{-1} \text {; } \\
& \text { Child } 6,840 \mathrm{~m}^{3} / \mathrm{yr} \text {; } \\
& t=\text { transit time between release and exposure, sec (calculated }
\end{aligned}
$$

Dose to the 50 -mile population, $\mathrm{D}$ (pop) $\left.=\Sigma\left[\mathrm{P}_{\mathrm{jk}} \mathrm{D} \text { (ind) }\right)_{\mathrm{jk}}\right]$

where $P_{j k}$ is equal to the $j^{\text {th }}$ age group population in the $\mathrm{k}^{\text {th }}$ annulus. Pop dose is:

\begin{tabular}{ccccccc}
\hline $\begin{array}{c}\text { Annulus } \\
\text { Radii }\end{array}$ & $\begin{array}{c}\text { Population Population } \\
(j=1)\end{array}$ & $\begin{array}{c}\text { Child } \\
(j=2)\end{array}$ & X/Q & $\begin{array}{c}\text { Adult/Teen } \\
\text { Ind. Dose } \\
(\text { rem })\end{array}$ & $\begin{array}{c}\text { Child } \\
\text { Ind. Dose } \\
\text { (rem) }\end{array}$ & $\begin{array}{c}\text { Population } \\
\text { Dose } \\
\text { (per-rem) }\end{array}$ \\
\hline $5-10$ & 1369 & 402 & $7.34 \times 10^{-7}$ & 1.2 & 0.76 & 1.6 \\
$10-20$ & 5673 & 1666 & $3.17 \times 10^{-7}$ & 0.50 & 0.32 & 1.5 \\
$20-30$ & 104784 & 30771 & $1.88 \times 10^{-7}$ & 0.30 & 0.19 & 47 \\
$30-40$ & 15881 & 4664 & $1.33 \times 10^{-7}$ & 0.21 & 0.14 & 7.6 \\
$40-50$ & 1483 & 435 & $1.01 \times 10^{-7}$ & 0.16 & 0.10 & 1.2
\end{tabular}

AXAIR89Q Estimate: 58 per-rem

Total: $\mathbf{5 9}$ per-rem 
hemisphere above ground level. The gamma-shine external dose is therefore directly proportional to the integral air concentration and is determined by multiplying the integral concentration by an infinite-plume shine dose factor. The external dose for a given nuclide, $n$, is expressed as:

$$
D_{n}=(X / Q)\left(Q_{n}\right)\left(D F_{s}\right)_{n} e^{-\lambda_{n} t}
$$

where $X / Q$ is the relative air concentration at the receptor integrated over time, $Q_{n}$ is the release rate of the radionuclide, $\left(D F_{s}\right)_{n}$ is the shine dose factor ${ }^{20}$ for nuclide $n$ expressed in units of mrem/yr per $\mu \mathrm{Ci} / \mathrm{m}^{3}, \lambda_{\mathrm{B}}$ is the decay constant for nuclide $n$, and $t$ is the transit time between release and exposure. No attenuation is assumed for calculations of dose to the maximum individual. A comparison of shine doses derived using the uniform plume model in AXAIR89Q and by hand-calculation is given in Table 6.1. The doses presented in the table are for the maximum individual at the site boundary. Supporting calculations for the data in Table 6.1 are located on pages $\mathrm{C} 1$ through $\mathrm{C} 5$ in Appendix $\mathrm{C}$.

Table 6.1. Comparison of External Dose*: AXAIR89Q to Hand-Calculations

\begin{tabular}{llll}
\hline Nuclide & $\begin{array}{c}\text { AXAIR89Q } \\
\text { Dose (mrem) }\end{array}$ & $\begin{array}{c}\text { Hand-Calculation } \\
\text { Dose (mrem) }\end{array}$ & $\begin{array}{c}\text { Percent } \\
\text { Difference }\end{array}$ \\
\hline H-3 & - & - & - \\
Be-7 & $3.42 \times 10^{-5}$ & $3.42 \times 10^{-5}$ & 0.0 \\
C-14 & - & - & - \\
N-13 & $3.00 \times 10^{-5}$ & $2.99 \times 10^{-5}$ & 0.3 \\
F-18 & $6.79 \times 10^{-4}$ & $6.79 \times 10^{-4}$ & 0.0 \\
Mg-27 & $2.32 \times 10^{-5}$ & $2.32 \times 10^{-5}$ & 0.0 \\
Ar-41 & $3.39 \times 10^{0}$ & $3.39 \times 10^{0}$ & 0.0 \\
I-135 & $5.27 \times 10^{-3}$ & $5.26 \times 10^{-3}$ & 0.2 \\
& & &
\end{tabular}

Dose, using the uniform plume model, to the maximum individual at the site boundary; $11870 \mathrm{~m}$ in the NNW sector.

The shine dose to a given population is determined in the same way as above for an individual except that an attenuation factor is included to account for partial shielding by building structures. AXAIR $89 \mathrm{Q}$ currently provides a population dose reduction of $50 \%$ due to attenuation. The population dose from a given nuclide is calculated by: 


$$
D_{n}(p o p)=(0.5)\left(Q_{n}\right)\left(D F_{s}\right)_{n} \quad \Sigma_{j}\left[(X / Q)_{j}\left(P_{j}\right) e^{-\lambda_{n} l}\right]
$$

where 0.5 is the factor for building attenuation, $(X / Q)_{j}$ is the average relative concentration in the sector/radial region $\mathrm{j}$, and $\mathrm{P}_{\mathrm{j}}$ is the population in that region. An example of the population dose to the WNW sector from Ar-41 gamma-shine is presented in Figure 6.1.

\section{NON-UNIFORM PLUME MODEL}

In the non-uniform plume model, the gaussian nature of the downwind plume is accounted for when determining air concentrations at and around exposed individuals. Because gamma attenuation between the point source and the receptor is a function of energy, gamma shine integrals are determined for a number of energy categories. These categories or ranges each have a characteristic photon energy on which exposure calculations are based. The shine integral for a given nuclide and energy category is the product of the integral air concentration at the receptor, the point source at the receptor integrated over the dimensions of the plume, the buildup factor, and the air absorption coefficient. The relative shine integral, $S(x)$, is:

$$
S(x)=C_{a} \cdot I
$$

where $C_{a}$ is the relative air concentration model and $I$ is the integral function for a given set of meteorological conditions (i.e., fumigation vs non-fumigation, two-hour vs annual average concentrations, etc.). The two-hour, non-fumigation integral function, I, is defined as,

$$
I=\mu_{a} \int_{z=0}^{\infty} \int_{y=-\infty}^{\infty} \int_{x=-\infty}^{\infty} \frac{B(\mu r) e^{-\mu r}}{4 \pi r^{2}} e^{-y^{2} / 2 \sigma_{y}^{2}} H(z) d x d y d z
$$

where $H(z)=\exp \left[-(z-h)^{2} / 2 \sigma_{z}^{2}\right]+\exp \left[-(z+h)^{2} / 2 \sigma_{z}^{2}\right]$. The two-hour, fumigation integral function, $\mathrm{I}_{\mathrm{F}}$, is defined as,

$$
I_{F}=2 \mu_{a} \int_{z=0}^{L} \int_{y=-\infty}^{\infty} \int_{x=-\infty}^{\infty} \frac{B(\mu r) e^{-\mu r}}{4 \pi r^{2}} e^{-y^{2} / 2 \sigma_{y}^{2}} d x d y d z
$$


Figure 6.1 Offsite Population Dose Calculation for External Exposure to Ar-41.

Release Amount: $5.0 \times 10^{3} \mathrm{Ci}$ Ar-41 (in 2 hour period)

Release Type: 50 Meter Stack from H-Area (E64257;N70415)

Max. Population Sector: WNW (68.3\% Adult, 9.0\% Teen, $22.7 \%$ Child)

Dose to a given individual, $\mathrm{D}(\text { ind })_{\mathrm{jk}}$ :

$$
\begin{aligned}
& \mathrm{D}(\text { ind })_{j \mathrm{k}}=0.0317(0.5)(\mathrm{Q})(\mathrm{X} / \mathrm{Q})_{\mathrm{k}}(\mathrm{DF}) \mathrm{e}^{-\lambda t} \\
\text { where } 0.0317= & \text { conversion factor, years per second and } \mu \mathrm{Ci} \text { per } \mathrm{Ci} ; \\
0.5= & \text { partial shielding of population from building structures; } \\
\mathrm{Q}= & \text { total release, } 5000 \text { curies; } \\
\mathrm{X} / \mathrm{Q}_{\mathrm{k}}= & \text { sector-arc relative concentration at } \mathrm{k}^{\text {th }} \text { distance, sec } / \mathrm{m}^{3} \\
& \text { (receptor distance is the center of the population area); } \\
\mathrm{DF}= & \text { Argon- } 41 \text { external dose factor for immersion in contaminated } \\
& \text { air, } 6620 \mathrm{mrem} \mathrm{m}^{3} / \mu \mathrm{Ci} \text { yr; } \\
\lambda= & \text { Argon- } 41 \text { decay constant, } 1.05 \times 10^{-4} \mathrm{sec}^{-1} ; \\
\mathrm{t}= & \text { transit time between release and exposure, sec (calculated by } \\
& \text { distance divided by windspeed of } 1.99 \mathrm{~m} / \mathrm{sec}) .
\end{aligned}
$$

Dose to the 50 -mile population, $D(p o p)=\Sigma\left[P_{j k} D(\text { ind })_{j k}\right]$ where $P_{j k}$ is equal to the $j^{\text {th }}$ age group population in the $k^{\text {th }}$ annulus. Pop dose is:

\begin{tabular}{cccccc}
\hline $\begin{array}{c}\text { Annulus } \\
\text { Radii }\end{array}$ & $\mathrm{X} / \mathrm{Q}$ & $\mathrm{e}^{-\lambda s}$ & $\begin{array}{c}\text { Ind. Dose } \\
\text { (mrem) }\end{array}$ & Population & $\begin{array}{c}\text { Pop.Dose } \\
\text { (per-rem) }\end{array}$ \\
\hline $5-10$ & $7.12 \times 10^{-7}$ & 0.53 & 0.20 & 1448 & 0.3 \\
$10-20$ & $3.32 \times 10^{-7}$ & 0.28 & 0.047 & 3318 & 0.15 \\
$20-30$ & $1.89 \times 10^{-7}$ & 0.12 & 0.012 & 169074 & 2.0 \\
$30-40$ & $1.30 \times 10^{-7}$ & 0.051 & 0.0036 & 39258 & 0.14 \\
$40-50$ & $9.89 \times 10^{-8}$ & 0.022 & 0.0012 & 8154 & 0.0095 \\
\hline
\end{tabular}

AXAIR89Q Estimate: 2.5 per-rem

Total: 2.6 per-rem 
The highest concentrations are expected to be found on the plume centerline so that an upper-bound approximation of the integral functions given above can be determined by letting $y=0$ in equations 6.4 and 6.5 . The upper-bound approximation of the two-hour, non-fumigation integral function becomes,

$$
\bar{I}=\mu_{a} \int_{z=0}^{\infty} \int_{y=-\infty}^{\infty} \int_{x=-\infty}^{\infty} \frac{B(\mu r) e^{-\mu r}}{4 \pi^{2}} H(z) d x d y d z
$$

and the upper-bound approximation of the two-hour, fumigation integral function is,

$$
\bar{I}_{F}=2 \mu_{a} \int_{z=0}^{L} \int_{y=-\infty}^{\infty} \int_{x=-\infty}^{\infty} \frac{B(\mu r) e^{-\mu r}}{4 \pi r^{2}} d x d y d z
$$

The annual average integral function is determined by multiplying the upper-bound approximation $(y=0)$ integral function for non-fumigation by $6.383 \sigma_{\mathrm{y}} / \mathrm{x}$, the sectorarc averaging factor, where $x$ is the downwind distance between the receptor and the release point.

The shine integrals introduced above and their analytical solutions can be found in Appendix $E$ of reference 1. The FORTRAN subroutines that calculate the shine integrals were found to be consistent with these solutions. The shine integral calculations are performed in the subroutines found in member GRAYSUB located in the TENVT.TMECA.FORT dataset. Reference 1 should be consulted for a detailed discussion on the estimation of the shine integrals.

Individual and population doses are determined in a fashion similar to the semiinfinite plume methodology, i.e., the dose estimate is the product of the shine integral and the energy-category dose factor summed over all energy categories and source nuclides as follows:

$$
D_{n}=\Sigma_{n} \Sigma_{m}\left[D F_{m n} S(x)_{m n}\right]
$$

where $m$ ranges from 1 to 23 for each gamma-ray energy group and $n$ ranges over all nuclides in the source term that contribute to the shine dose. In equation $6.8, D_{n}$ is the dose from nuclide $\mathrm{n}$ at a single receptor location, $D F_{\mathrm{mn}}$ is the shine dose factor for nuclide $\mathrm{n}$ and energy range $\mathrm{m}$, and $\mathrm{S}(\mathrm{x})_{\mathrm{mn}}$ is as defined in equation 6.3.

The external dose factors for the 23 energy groups referenced above are determined for a point source exposing a receptor in space. As evidenced in Equations 6.4 
through 6.7, the non-uniform model (and the upper-bound approximation) evaluates the exposure region integral in the vertical direction from ground level to the inversion lid. Since the uniform plume model does not inherently assume a hemispherical exposure region, one-half of the sum of the 23 external dose factors for a given nuclide is used as the uniform plume dose factor to calculate the semiinfinite plume external dose. Results from the three gamma-exposure models of AXAIR89Q are given in Table 6.2.

The uniform plume model assumes that the concentration of a given nuclide is uniform throughout the hemisphere above ground level and is equal to the concentration at the receptor. The non-uniform plume model, on the other hand, estimates the nuclide concentration at all locations that could potentially expose the receptor. Therefore, it is expected that higher dose estimates would result from use of the uniform plume model than from the more rigorous non-uniform plume model. The upper-bound approximation of the non-uniform plume model assumes that the nuclide concentration in the lateral direction is equal to the concentration at the centerline of the plume (i.e., $y=0$ ). This assumption means that the upperbound approximation will result in doses larger than the rigorous non-uniform method yet smaller than the uniform plume method.

Table 6.2. External Shine Dose Using AXAIR89's Three Plume Models*

$\begin{array}{lccc} & & \text { Upper Bound } \\ \text { Receptor } & \text { Uniform } & \text { Non-Uniform } & \text { Non-Uniform } \\ \text { Plume } & \text { Plume } & \text { Plume }\end{array}$

99.5\% Maximum Individual (mrem)

$\begin{array}{llll}\text { Boundary, NNW } & 3.40 \times 10^{0} & 2.08 \times 10^{0} & 1.96 \times 10^{0} \\ 50 \text { Miles, SW } & 4.01 \times 10^{-2} & 3.38 \times 10^{-2} & 3.36 \times 10^{-2}\end{array}$

50-Mile Population, WNW (per-rem) $2.54 \times 10^{0} \quad 2.44 \times 10^{0} \quad 2.44 \times 10^{0}$

shine doses are for the hypothetical scenario given in Section 1.

As predicted, the uniform plume model produces the highest doses, the non-uniform plume model produces the lowest doses, and the upper-bound approximation results in doses between the other two. 


\section{DATABASES}

Several data files are accessed by the six modules that make up AXAIR89Q. Those data files include: 1) boundary coordinates, 2) offsite population distribution, 3) onsite population distribution, 4) terrain heights, 5) meteorological joint frequency distributions, 6) dose factors, and 7) daughter ingrowth libraries. Table 7.1 gives the dataset parameters and names of each of these files.

Where possible, data files have been reviewed for accuracy. Some databases, however, are stored as binary files and are, therefore, inaccessible. The contents of binary files are verified by examination of the products generated from operations on these files, i.e., relative terrain heights and population distributions. The arrays generated by these files have been checked against similar arrays generated by POPGASP21. 
Table 7.1. Data files accessed by AXAIR89Q routines.

\begin{tabular}{|c|c|c|c|c|}
\hline Description & File Name(a) & $\begin{array}{c}\text { Binary/ } \\
\text { ASCII }\end{array}$ & $\begin{array}{c}\text { Partitioned/ } \\
\text { Sequential }\end{array}$ & $\begin{array}{l}\text { Review } \\
\text { Reference }\end{array}$ \\
\hline Boundary Coordinates & $\begin{array}{l}\text { TMECA } \\
\text { DATA(SRSB }\end{array}$ & $\begin{array}{r}A \\
\text { DRY) }\end{array}$ & $P$ & 22 \\
\hline $100 \mathrm{mi}$. Offsite Population & $\begin{array}{l}\text { POP } 100 \\
\text { DATA }\end{array}$ & B & $S$ & 21 \\
\hline Onsite Population & $\begin{array}{l}\text { AXAIR } \\
\text { ONPOP89 }\end{array}$ & B & $S$ & 24 \\
\hline $100 \mathrm{mi}$. Terrain Elevations & $\begin{array}{l}\text { TPGY } 100 \\
\text { DATA }\end{array}$ & B & $S$ & 21 \\
\hline Meteorological JFDs & $\begin{array}{l}\text { SRP62M } \\
\text { WINDS(H828 }\end{array}$ & $500)^{A}$ & $P$ & 4,5 \\
\hline ICRP2 Dose Factors & $\begin{array}{l}\text { AXAIR } \\
\text { DFLIB }\end{array}$ & A & $S$ & $=$ \\
\hline ICRP30 Dose Factors & $\begin{array}{l}\text { TMECA } \\
\text { FORT(DFIC) }\end{array}$ & 30) & $\mathrm{P}$ & 23 \\
\hline Daughter Ingrowth Lib. & $\begin{array}{l}\text { PRIMUS } \\
\text { DECAYLIB }\end{array}$ & A & $S$ & $\#$ \\
\hline
\end{tabular}

(a)IBM File names consist of PROJECT, GROUP, TYPE, and MEMBER (for partitioned datasets). The PROJECT name for all files listed above is "TENVT; the GROUP, TYPE, and MEMBER names are given in the table.

- ICRP2 dose factor library not verified.

\# This report. 


\section{REFERENCES}

1.) Pillinger, W.L. and Huang, J.C., AXAIR: A Computer Code for SAR Assessment of Plume-Exposure Doses From Potential Process-Accident Releases to Atmosphere, DPST-85-304, E.I. DuPont de Nemours, Savannah River Laboratory, Aiken, SC, 1986.

2.) Hermann, O.W., Baes, C.F., Miller, C.W., Begovich, C.L., and Sjoreen, A.L., PRIMUS: A Computer Code for the Preparation of Radionuclide Ingrowth Matrices from User-Specified Sources, ORNL-5912, Oak Ridge National Laboratory, Oak Ridge, Tennessee, 1984.

3.) Atmospheric Dispersion Models for Potential Accident Consequence Assessments at Nuclear Power Plants, US NRC Regulatory Guide 1.145, US Nuclear Regulatory Commission, Washington, DC, Rev. 1, November 1982.

4.) Garrett, A.J., and Hoel, D.D., Preparation of Meteorological Data for Dose Calculations in 1982 SRP Reactor Safety Analysis Report (SAR), DPST-82512, E.I. DuPont de Nemours, Savannah River Laboratory, Aiken, SC, 1982.

5.) Lauriant, J.E., Average Wind Statistics for SRP Area Meteorological Towers, DPST-87-341, E.I. DuPont de Nemours, Savannah River Laboratory, Aiken, SC, 1987.

6.) Meteorology and Atomic Energy, D.H. Slade (ed.), TID-24190, U.S. Atomic Energy Commission, Oak Ridge, Tennessee, 1968.

7.) Pasquill, F., The Estimation of the Dispersion of Windborne Material, MeteoroL Mag., 90(1063):33-49, 1961.

8.) Pasquill, F., Atmospheric Diffusion, D. Van Nostrand Company, Ltd., London 1962.

9.) Eimutis, E.C., and Konieck, M.G., "Derivations of Continuous Functions for the Lateral and Vertical Atmospheric Dispersion Coefficients", Atmospheric Environment, Vol. 6, pp. 859-863, 1972.

10.) Turner, D.B., Workbook of Atmospheric Dispersion Estimates, U.S. Department of Health, Education, and Welfare, Public Health Service, Cincinnati, Ohio, pg. 7, 1967. 
11.) Stull, Robert B., An Introduction to Boundary Layer Meteorology, Kluwer Academic Publishers, Boston, pp. 376-379, 1988.

12.) Pendergast, M.M., Power Law Profiles of Mean Winds and Horizontal and Vertical Standard Deviations of Wind Direction at the Savannah River Plant, DP-1455, Savannah River Laboratory Environmental Transport and Effects Research: Annual Report, E.I. DuPont de Nemours, Savannah River Laboratory, Aiken, SC, pp. 167-169, 1976.

13.) Code of Federal Regulations, Title 10 Part 100: Reactor Site Criteria, Office of the Federal Register, National Archives and Records Administration, Washington, DC, January 1987.

14.) Methods for Estimating Atmospheric Transport and Dispersion of Gaseous Effluents in Routine Releases from Light-Water-Cooled Reactors, US NRC Regulatory Guide 1.111, US Nuclear Regulatory Commission, Washington, DC, Rev. 1, July 1977.

15.) International Commission on Radiological Protection, Permissible Dose for Internal Radiation, Publication 2, Pergamon Press, New York, 1959.

16.) International Commission on Radiological Protection, Limits for Intake of Radionuclides by Workers, Publication 30, Part 1, Pergamon Press, Vol. 2, No. 3, pg. 65, 1979.

17.) Intemal Dose Conversion Factors for Calculation of Dose to the Public, DOE/EH-0071, U.S. Department of Energy, Washington, DC, 1988.

18.) Huang, J.C., and DelGenio, M.E., Use of the Current ICRP30 Dose Factor Library to Determine Uranium and Plutonium Doses in the AXAIR89Q Code, WSRC-TR-90-316, Westinghouse Savannah River Company, Savannah River Laboratory, Aiken, SC, 1990.

19.) Huang, J.C. and Marter, W.L., Recommended Breathing Rates for SAR Accident Dose Calculations, DPST-83-930, E.I. du Pont de Nemours, Inc., Savannah River Laboratory, Aiken, SC, 1983.

20.) External Dose-Rate Conversion Factors for Calculation of Dose to the Public, DOE/EH-0070, U.S. Department of Energy, Washington, DC, 1988. 
21.) Hamby, D.M., "Comparison of the Terrain Height and Offsite Population Distributions Generated by POPGASP and AXAIR89Q", SRL-ETS-900467, Westinghouse Savannah River Company, Aiken, SC, 1990.

22.) Bauer, L.R., "Site Boundary File Used By Maxigasp and AXAIR89Q", SRL-ETS90-331, Westinghouse Savannah River Company, Savannah River Laboratory, Aiken, SC, 1990.

23.) Hamby, D.M., "Upgrade and Verification of the ICRP30 Dose Factor Library For $A X A I R 89 Q$ and AXAOTHER", SRL-ETS-900479, Westinghouse Savannah River Company, Savannah River Laboratory, Aiken, SC, 1990.

24.) Huang, J.C. and Oakley, R.A., "1989 Onsite Day-Shift Population Distribution at $S R S^{n}$, WSRC-RP-89-1294, Westinghouse Savannah River Company, Savannah River Laboratory, Aiken, SC, 1989. 
APPENDIXA 


\section{Appendix A.}

The following is a sample calculation of relative air concentration downwind of a stack release. The relative air concentration in the NNW direction at the site boundary (11870 meters) will be estimated for a release from a 50-meter stack at the geographical center of the SRS. Following this sample calculation is the printout from an electronic spreadsheet designed to calculate the relative concentration as explained below. The following parameters are held constant throughout the calculation: 1) inversion height: 200 meters, 2) number of meteorological observations: 35252,3 ) meteorology observation height: 62 meters, 4) stability category: E, and 5) wind speed category: 2.

STEP

ACTION

1.

Read frequency, $\mathrm{f}_{\mathrm{ij}}$, of meteorological observations for each wind speed range, $i$, and stability category, $j$, and generate joint frequency distrbution, $\mathrm{JFD}_{\mathrm{ij}}$. From a total of 35252 observations, stability category $E$ and wind speed category 2 were recorded 221 times.

EXAMPLE: $J F D_{i j}=(100) f_{i j}$ 35252

$$
\mathrm{JFD}_{\mathrm{E}, 2}=\frac{(100)(221)}{35252}=0.6269
$$

2. Read reciprocal average wind speeds, $U A_{i j}$, for each wind speed category, $\mathrm{i}$, and stability category, $\mathrm{j}$. Wind file shows an average wind speed of $3.23 \mathrm{~m} / \mathrm{sec}$ for stability category $E$ and wind speed category 2.

EXAMPLE: UAE,2 $=3.23$ meters $/$ second

3. Determine, from the terrain file, the maximum terrain height, $\mathrm{H}_{\mathrm{t}}$, between the release point and the receptor. Terrain file shows a maximum terrain height of +154.3 feet relative to the release location.

EXAMPLE: $H_{t}=154.3$ feet $=47.0$ meters 
4. Calculate the effective release height, $\mathrm{H}_{\mathrm{e}}$, and the effective inversion height, Le.

EXAMPLE: $\mathrm{H}_{\mathrm{e}}=\mathrm{H}_{\mathrm{s}}-\mathrm{H}_{\mathrm{t}}=50 \mathrm{~m}-47.0 \mathrm{~m}=3 \mathrm{~m}$

$$
L_{e}=L-H_{t}=200 m-47.0 m=153 m
$$

5. Calculate the adjusted wind speeds for determining the wind speed at the release height, $U_{H S}$, and the wind speed at the effective release height, $U_{\mathrm{HE}}$. (Note: the wind speed below 10 meters is always determined at the 10 meter level.)

EXAMPLE: $U_{H S_{i j}}=U A_{i j}\left(H_{s} / M H\right) C E_{i}$

$$
\begin{aligned}
& U_{H E_{i j}}=U A_{i j}\left(H_{e} / M H\right)^{C E_{i}} \\
& U_{H S_{E_{2}}}=3.23(50 \mathrm{~m} / 62 \mathrm{~m})^{0.31}=3.02 \mathrm{~m} / \mathrm{sec} \\
& U_{H E_{E, 2}}=3.23(3 \mathrm{~m} / 62 \mathrm{~m})^{0.31}=1.83 \mathrm{~m} / \mathrm{sec}
\end{aligned}
$$

6. Calculate $\sigma_{y}$ and $\sigma_{z}$ at a distance equal to the receptor distance, $x$, for each stability category, $i$ (see Tables 1 and 2).

EXAMPLE: $\sigma_{y_{i}}=A x^{B} \quad \sigma_{z_{i}}=A x^{B}+C$

$$
\begin{aligned}
& \sigma_{y_{E}}=0.1046(11870)^{0.9031}=500.2 \mathrm{~m} \\
& \sigma_{Z_{E}}=6.73(11870)^{0.305}+(-34)=83.69 \mathrm{~m} \\
& \sigma_{Z}(\max )=(0.8) \mathrm{L}_{e}=160 \mathrm{~m}
\end{aligned}
$$


7. Calculate centerline, two-hour relative air concentration, $X_{2_{i j}} / Q$, and two-hour, sector-arc average relative concentration, $X_{2 a r c i j} / Q$, for nonfumigations conditions.

$$
\begin{aligned}
& \text { EXAMPLE: } \mathrm{X}_{\mathrm{ij}_{\mathrm{j}}} / \mathrm{Q}=\exp \left(-\mathrm{H}_{\mathrm{e}}^{2} / 2 \sigma_{\mathrm{z}_{\mathrm{i}}}^{2}\right) \\
& \pi \sigma_{y_{i}} \sigma_{z_{i}} U_{H S} \\
& X_{2 \operatorname{arc}_{i j}} / Q=X_{2_{i j}} / Q\left(6.38308 \sigma_{y_{i}} / x\right) \\
& \mathrm{X}_{2 \mathrm{ij}} / \mathrm{Q}=\quad \exp \left(-3 \mathrm{~m}^{2} / 2(83.69 \mathrm{~m})^{2}\right) \\
& (3.14159)(500.2 \mathrm{~m})(83.69 \mathrm{~m})(3.02 \mathrm{~m} / \mathrm{sec}) \\
& \mathrm{X}_{2 \mathrm{ij}} / \mathrm{Q}=2.52 \times 10^{-6} \mathrm{sec} / \mathrm{m}^{3} \\
& \mathrm{X}_{2 \mathrm{arc}_{\mathrm{ij}}} / \mathrm{Q}=\left(2.52 \times 10^{-6} \mathrm{sec} / \mathrm{m}^{2}\right)(6.38308)(500.2 \mathrm{~m}) \\
& (11870 \mathrm{~m}) \\
& \mathrm{X}_{2 \operatorname{arcij}} / \mathrm{Q}=6.78 \times 10^{-7} \mathrm{sec} / \mathrm{m}^{3}
\end{aligned}
$$

NOTE: Recall that $\mathrm{X}_{2 \operatorname{arc} c_{i j}} / \mathrm{Q}$ cannot exceed $\mathrm{X}_{2_{\mathrm{ij}}} / \mathrm{Q}$.

8. Determine if fumigation relative air concentrations for two-hour, centerline, $X_{2 f} / Q$, and two-hour, sector-arc, $X_{2 f a r c} / Q$, are to be calculated.

1) Stability category $E, F$, or $G$ ?

2) Wind speed less than $4.0 \mathrm{~m} / \mathrm{sec}$ ?

3) Is the effective inversion height greater than the square root of $(x / 2) \sigma_{z}$ ?

Stability Category $=\mathrm{E}$.

Wind Speed $=3.23 \mathrm{~m} / \mathrm{sec}$

$\mathrm{L}_{e}=153 \mathrm{~m} ; \operatorname{SQRT}(\pi / 2) \sigma_{\mathrm{z}}=\operatorname{SQRT}(\pi / 2)(83.69 \mathrm{~m})=66.8 \mathrm{~m}$ (thus, $L_{e}$ is greater than $\operatorname{SQRT}(\pi / 2) \sigma_{z}$ and fumigation $X / Q$ s must be calculated). 
EXAMPLE: $X_{2 f_{i j}} / Q=1 /\left(\operatorname{SQRT}(2 \pi) \sigma_{y_{i}} L_{e} U_{H S_{i j}}\right)$

$$
\begin{aligned}
& \mathrm{X}_{2 \mathrm{farc}_{\mathrm{ij}_{\mathrm{j}}}} / \mathrm{Q}=\mathrm{X}_{2 \mathrm{fi}_{\mathrm{ij}}} / \mathrm{Q}\left(6.38308 \sigma_{\mathrm{y}_{\mathrm{i}}} / \mathrm{x}\right) \\
& \mathrm{X}_{2 \mathrm{fij}_{\mathrm{ij}}} / \mathrm{Q}=1 /(\operatorname{SQRT}(2 \pi)(500.2 \mathrm{~m})(153 \mathrm{~m})(3.02 \mathrm{~m} / \mathrm{sec}) \\
& X_{2 f_{i j}} / Q=1.73 \times 10^{-6} \mathrm{sec} / \mathrm{m}^{3} \\
& X_{2 f a r c i j} / Q=\left(1.73 \times 10^{-6} \mathrm{sec} / \mathrm{m}^{3}\right)(6.38308)(500.2 \mathrm{~m}) \\
& (11870 \mathrm{~m}) \\
& X_{2 f_{a r c a j}} / Q=4.65 \times 10^{-7} \mathrm{sec} / \mathrm{m}^{3}
\end{aligned}
$$

9. Determine if weighted sum of $X_{2} / Q$ and $X_{2 f} / Q$ is to be used for twohour centerline and sector-arc relative concentrations.

EXAMPLE: $\mathrm{X}_{2 \mathrm{fi}_{\mathrm{i}}} / \mathrm{Q}$ does not exceed $\mathrm{X}_{2_{\mathrm{ij}}} / \mathrm{Q}$ so two-hour, centerline relative air concentration $=X_{2, j} / Q$.

$\mathrm{X}_{2 \mathrm{farc}} / \mathrm{Q}$ does not exceed $\mathrm{X}_{2 \text { arcij }} / \mathrm{Q}$ so two-hour, sector-arc relative air concentration $=\mathrm{X}_{2 \mathrm{arcij}} / \mathrm{Q}$.

10. Calculate the 99.5 percentile two-hour centerline and sector-arc concentrations from each array of $42 \mathrm{X}_{2} / \mathrm{Q}^{\prime} \mathrm{s}$ determined for this sector.

EXAMPLE:

\begin{tabular}{lccc} 
& $\begin{array}{c}\text { Sorted Array } \\
\text { of Sector } \\
\mathrm{X}_{2} / \mathrm{O}^{\prime} \text { ' }\left(\mathrm{sec} / \mathrm{m}^{3}\right)\end{array}$ & Frequency & Cum Freq \\
\cline { 3 - 4 } $\mathrm{ij}$ & $4.56 \times 10^{-5}$ & 0.0397 & 0.0397 \\
$\mathrm{~F}, 1$ & $1.07 \times 10^{-5}$ & 0.0426 & 0.0823 \\
$\mathrm{E}, 1$ & $9.53 \times 10^{-6}$ & 0.0142 & 0.0965 \\
$\mathrm{G}, 3$ & $7.23 \times 10^{-6}$ & 0.0028 & 0.0993 \\
$\mathrm{G}, 4$ & $6.07 \times 10^{-6}$ & 0.1305 & 0.2298 \\
$\mathrm{~F}, 2$ & 6.05 & 0.2950 & 0.5248 \\
$\mathrm{~F}, 3$ & $4.17 \times 10^{-6}$ & &
\end{tabular}


The cumulative frequency has increased beyond 0.5 . An interpolation is now performed to determine the $\mathrm{X}_{2} / \mathrm{Q}$ that occurs less than 0.5 percent of the time. The interpolated two-hour, centerline $X / Q$ for the north-northwest sector is equal to $4.33 \times 10^{-6} \mathrm{sec} / \mathrm{m}^{3}$.

$\begin{array}{lccc}\text { Sorted Array } & & \\ \text { of Sector } \\ \text { i.j } & X_{2 \text { arc } / O^{\prime} \text { 's }\left(\mathrm{sec} / \mathrm{m}^{3}\right)} & \text { Frequency } & \text { Cum Freq } \\ \mathrm{F}, 1 & 8.46 \times 10^{-6} & 0.0397 & 0.0397 \\ \mathrm{E}, 1 & 2.88 \times 10^{-6} & 0.0426 & 0.0823 \\ \mathrm{G}, 3 & 1.22 \times 10^{-6} & 0.0142 & 0.0965 \\ \mathrm{~F}, 2 & 1.13 \times 10^{-6} & 0.1305 & 0.2270 \\ \mathrm{D}, 1 & 1.07 \times 10^{-6} & 0.0454 & 0.2724 \\ \mathrm{G}, 4 & 9.27 \times 10^{-7} & 0.0028 & 0.2752 \\ \mathrm{C}, 1 & 8.90 \times 10^{-7} & 0.0511 & 0.3263 \\ \mathrm{~A}, 1 & 8.64 \times 10^{-7} & 0.2638 & 0.5901\end{array}$

The interpolated two-hour, sector-arc X/Q for the north-northwest sector is equal to $8.73 \times 10^{-7} \mathrm{sec} / \mathrm{m}^{3}$.

11. Determine annual, sector-arc relative air concentration, $\mathrm{X}_{\mathrm{arc}_{\mathrm{ij}}} / \mathrm{Q}$, for each combination of wind speed and stability category to calculate annual average relative concentration, $X_{a} / Q$.

EXAMPLE: $\mathrm{X}_{\mathrm{arc}} / \mathrm{Q}=2.032 \exp \left(-\mathrm{H}_{\mathrm{e}}{ }^{2} / 2 \sigma_{\mathrm{z}_{i}}{ }^{2}\right)$

$$
\begin{gathered}
\mathrm{U}_{\mathrm{HE}_{\mathrm{ij}}} \sigma_{\mathrm{z}_{\mathrm{i}}} \mathrm{X} \\
\mathrm{X}_{\operatorname{arc}, 2,2 / \mathrm{Q}=2.032 \exp \left(-3 \mathrm{~m}^{2} / 2(83.69 \mathrm{~m})^{2}\right)} \\
(1.83 \mathrm{~m} / \mathrm{sec})(83.69 \mathrm{~m})(11870 \mathrm{~m}) \\
\mathrm{X}_{\operatorname{arc} \mathrm{E}_{2} / \mathrm{Q}}=1.12 \times 10^{-6} \mathrm{sec} / \mathrm{m}^{3}
\end{gathered}
$$

NOTE: A centerline, two-hour $X / Q$ is calculated using UHE instead of $U_{H S}$. This value is compared with $X_{\text {arc }} / Q$ and the lesser of the two is used as the annual, sector-arc relative air concentration. 
12. Calculate annual average relative concentration from 42 annual sector-arc averaged $X_{\mathrm{aij}_{\mathrm{ij}}} / \mathrm{Q}^{\prime} \mathrm{s}$ and the joint frequency distribution obtained in Step 1. Annual average $X_{a} / Q$ equals the sum of the product of these two arrays.

$$
\begin{aligned}
& \text { EXAMPLE: } X_{\mathrm{a}(\mathrm{NNW})} / \mathrm{Q}=\mathrm{ij}\left(\mathrm{X}_{\mathrm{a}_{\mathrm{ij}}} / \mathrm{Q}\right)\left(\mathrm{JFD}_{\mathrm{ij}}\right) \\
& \mathrm{X}_{\mathrm{a}(\mathrm{NNW})} / \mathrm{Q}=4.861 \times 10^{-8} \mathrm{sec} / \mathrm{m}^{3}
\end{aligned}
$$

The following four pages contain a spreadsheet developed to expedite the above calculations. The flow of the spreadsheet is similar to the twelve steps of the calculations demonstrated previously. Page four of the spreadsheet presents the two-hour centerline, two-hour sector-arc, and annual average X/Qs calculated for each of the 42 combinations of meteorological conditions evaluated. The two-hour centerline, 99.5 percentile $\mathrm{X} / \mathrm{Q}$ is determined on the page following the spreadsheet. Similar calculations are performed in Appendices B and C for the detemination of individual and population dose. 

\begin{tabular}{lll}
\hline SECTOR: & NNW & 8 \\
\hline
\end{tabular}
Sector $1-8$ or 0 :
Sector $9-16$ or 0 :

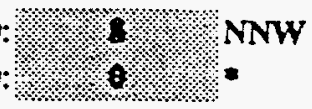

Only use for stack releases and at receptor distances greater than 1000 meters.

\begin{tabular}{c|cccc} 
Stab Cat & AZ(stab,3) & BZ(stab,3) & CZ(stab,3) & AY(stab) \\
\hline A & 0.00024 & 2.094 & -9.6 & 0.3658 \\
B & 0.055 & 1.098 & 2 & 0.2751 \\
C & 0.113 & 0.911 & 0 & 0.2089 \\
D & 1.26 & 0.516 & -13 & 0.1471 \\
E & 6.73 & 0.305 & -34 & 0.1046 \\
F & 18.05 & 0.18 & -48.6 & 0.0722
\end{tabular}

$\begin{aligned} \text { XDIS } & =11870 \\ \text { Terrain(ft) } & =1543 \\ \text { METHGT } & =62 \\ \text { RELHGT } & =50 \\ \text { METOBS } & =35252 \\ \text { Mix hgt } & =200 \\ \text { HT } & =47.0 \\ \text { HE } & =3.0 \\ \text { HLE } & =153.0 \\ \text { BY } & =0.9031\end{aligned}$

\begin{tabular}{|c|c|c|c|c|c|c|c|}
\hline \multirow{2}{*}{$\begin{array}{c}\text { Wind } \\
\text { Speed } \\
\text { Category }\end{array}$} & NNW & 74 & \multicolumn{3}{|c|}{$\begin{array}{l}\text { Observation Distribution } \\
\text { Stability Category }\end{array}$} & \multirow[b]{2}{*}{$F$} & \multirow[b]{2}{*}{ G } \\
\hline & $A$ & B & C & $\mathrm{D}$ & $E$ & & \\
\hline 1 & 93 & 15 & 18 & $16 \%$ & 15 & 18 & 80 \\
\hline 2 & 175 & 73 & 122 & 226 & 221 & 86. & 0 \\
\hline 3 & 38 & 26. & 79 & 312 & 363 & 104 & 3 \\
\hline 4 & 5 & 3 & 12 & 89. & 23 & 16 & 1 \\
\hline 5 & 2 & 0 & 4 & 19 & 0 & 0 & 0. \\
\hline 6 & 0 & 0 & 0 & 00 & $\theta$ & 0 & 0 \\
\hline
\end{tabular}

Cate
1
2
3
4
5

Average Wind Speeds (UA) (meters/sec)

Stability Category

\begin{tabular}{l|cccccc}
$\begin{array}{c}\text { Wind } \\
\text { Speed } \\
\text { Category }\end{array}$ & NNW & \multicolumn{5}{c}{$\begin{array}{c}\text { Average Wind Speeds (UA) (meters/sec) } \\
\text { Stability Category }\end{array}$} \\
\hline 1 \\
\hline 2
\end{tabular}

\begin{tabular}{|c|c|c|c|c|c|c|c|}
\hline \multirow{2}{*}{$\begin{array}{c}\text { Wind } \\
\text { Speed } \\
\text { Category }\end{array}$} & \multicolumn{7}{|c|}{$\begin{array}{c}\text { Joint Freqency Distribution } \\
\text { Stability Category }\end{array}$} \\
\hline & A & B & $\mathrm{C}$ & $\mathrm{D}$ & $E$ & $\mathbf{F}$ & $G$ \\
\hline 1 & 0.2638 & 0.0426 & 0.0511 & 0.0454 & 0.0426 & 0.0397 & 0.0000 \\
\hline 2 & 0.4964 & 0.2014 & 0.3461 & 0.6411 & 0.6269 & 0.1305 & $0.0000^{\circ}$ \\
\hline 3 & 0.1078 & 0.0738 & 0.2241 & 0.8851 & 1.0297 & 0.2950 & 0.0142 \\
\hline 4 & 0.0142 & 0.0085 & 0.0340 & 0.2525 & 0.0567 & 0.0284 & 0.0028 \\
\hline 5 & 0.0057 & 0.0000 & 0.0113 & 0.0539 & 0.0000 & 0.0000 & 0.0000 \\
\hline 6 & 0.0000 & 0.0000 & 0.0000 & 0.0000 & 0.0000 & 0.0000 & 0.0000 \\
\hline
\end{tabular}




\begin{tabular}{c|ccc} 
Stab. Cat. & CEXP & UHS factor & UHE factor \\
\hline A & 0.08 & 0.983 & 0.864 \\
B & 0.1 & 0.979 & 0.833 \\
C & 0.11 & 0.977 & 0.818 \\
D & 0.18 & 0.962 & 0.720 \\
E & 0.31 & 0.935 & 0.568 \\
F & 0.42 & 0.914 & 0.465 \\
G & 0.42 & 0.914 & 0.465
\end{tabular}

\begin{tabular}{|c|c|c|c|c|c|c|c|}
\hline \multirow{2}{*}{$\begin{array}{l}\text { Wind } \\
\text { Speed } \\
\text { Category }\end{array}$} & \multicolumn{7}{|c|}{ Average Wind Speeds (UHS) (m/sec) } \\
\hline & A & B & C & $\mathrm{D}$ & $E$ & $F$ & $G$ \\
\hline 1 & 1.24 & 1.32 & 1.20 & 1.10 & 0.71 & 0.41 & 0.00 \\
\hline 2 & 2.66 & 2.98 & 2.89 & 3.07 & 3.02 & 3.09 & 0.00 \\
\hline 3 & 4.50 & 4.63 & 4.70 & 4.66 & 4.57 & 4.49 & 4.84 \\
\hline 4 & 6.48 & 6.85 & 6.32 & 6.40 & 622 & 5.98 & 6.38 \\
\hline 5 & 8.47 & 0.00 & 8.42 & 8.53 & 0.00 & 0.00 & 0.00 \\
\hline 6 & 0.00 & 0.00 & 0.00 & 0.00 & 0.00 & 0.00 & 0.00 \\
\hline
\end{tabular}

\begin{tabular}{|c|c|c|c|c|c|c|c|}
\hline \multirow{2}{*}{$\begin{array}{c}\text { Wind } \\
\text { Speed } \\
\text { Category }\end{array}$} & \multicolumn{7}{|c|}{ Average Wind Speeds (UHE) (m/sec) } \\
\hline & A & B & C & $\mathrm{D}$ & $E$ & $F$ & $G$ \\
\hline 1 & 1.09 & 1.12 & 1.01 & 0.82 & 0.43 & 0.21 & 0.00 \\
\hline 2 & 2.34 & 2.53 & 2.42 & 2.30 & 1.83 & 157 & 0.00 \\
\hline 3 & 3.96 & 3.94 & 3.94 & 3.49 & 278 & 2229 & 2.46 \\
\hline 4 & 5.70 & 5.83 & 5.29 & 4.79 & 3.78 & 3.04 & 3.24 \\
\hline 5 & 7.45 & 0.00 & 7.05 & 6.39 & 0.00 & 0.00 & 0.00 \\
\hline 6 & 0.00 & 0.00 & 0.00 & 0.00 & 0.00 & 0.00 & 0.00 \\
\hline
\end{tabular}

Calculated Sigma (m)

\begin{tabular}{c|cc} 
Stab Cat. & Sigma Y & Sigma Z \\
\hline A & 1749.36 & 81669.52 \\
B & 1315.61 & 1639.23 \\
C & 999.02 & 581.97 \\
D & 703.48 & 146.51 \\
E & 500.23 & 83.69 \\
F & 345.28 & 49.10 \\
G & 238.33 & 28.80
\end{tabular}

Constrained Sigma (m)

\begin{tabular}{c|cc} 
Stab Cat. & Sigma Y & Sigma Z \\
\hline A & 1749.36 & 160.00 \\
B & 1315.61 & 160.00 \\
C & 999.02 & 160.00 \\
D & 703.48 & 146.51 \\
E & 500.23 & 83.69 \\
F & 345.28 & 49.10 \\
G & 238.33 & 28.80
\end{tabular}




\begin{tabular}{c|ccccccc}
$\begin{array}{c}\text { Wind } \\
\text { Speed } \\
\text { Category }\end{array}$ & A & B & C & Non-Fumigation 2 br Centerline Chi/Q \\
\hline 1 & $9.18 \mathrm{E}-07$ & $1.14 \mathrm{E}-06$ & $1.66 \mathrm{E}-06$ & $2.82 \mathrm{E}-06$ & $1.07 \mathrm{E}-05$ & $4.56 \mathrm{E}-05$ & $0.00 \mathrm{E}+00$ \\
2 & $4.27 \mathrm{E}-07$ & $5.08 \mathrm{E}-07$ & $6.89 \mathrm{E}-07$ & $1.01 \mathrm{E}-06$ & $2.51 \mathrm{E}-06$ & $6.07 \mathrm{E}-06$ & $0.00 \mathrm{E}+00$ \\
3 & $2.53 \mathrm{E}-07$ & $3.27 \mathrm{E}-07$ & $4.24 \mathrm{E}-07$ & $6.63 \mathrm{E}-07$ & $1.66 \mathrm{E}-06$ & $4.17 \mathrm{E}-06$ & $9.53 \mathrm{E}-06$ \\
4 & $1.76 \mathrm{E}-07$ & $2.21 \mathrm{E}-07$ & $3.15 \mathrm{E}-07$ & $4.83 \mathrm{E}-07$ & $1.22 \mathrm{E}-06$ & $3.13 \mathrm{E}-06$ & $7.23 \mathrm{E}-06$ \\
5 & $1.34 \mathrm{E}-07$ & $0.00 \mathrm{E}+\infty$ & $2.37 \mathrm{E}-07$ & $3.62 \mathrm{E}-07$ & $0.00 \mathrm{E}+00$ & $0.00 \mathrm{E}+\infty 0$ & $0.00 \mathrm{E}+\infty$ \\
6 & $0.00 \mathrm{E}+00$ & $0.00 \mathrm{E}+00$ & $0.00 \mathrm{E}+\infty$ & $0.00 \mathrm{E}+\infty$ & $0.00 \mathrm{E}+\infty$ & $0.00 \mathrm{E}+00$ & $0.00 \mathrm{E}+\infty$
\end{tabular}

\begin{tabular}{|c|c|c|c|c|c|c|c|}
\hline \multirow{2}{*}{$\begin{array}{c}\text { Wind } \\
\text { Speed } \\
\text { Category }\end{array}$} & \multicolumn{7}{|c|}{$\begin{array}{l}\text { Fumigation } 2 \text { hr Centerline Chi/Q } \\
\text { Stability Category }\end{array}$} \\
\hline & A & B & C & D & $E$ & $F$ & G \\
\hline 1 & & & & & $733 E-06$ & $1.84 \mathrm{E}-05$ & $0.00 \mathrm{E}+00$ \\
\hline 2 & & & & & $1.73 E-06$ & $2.45 E-06$ & $0.00 \mathrm{E}+\infty 0$ \\
\hline 3 & & & & & $0.00 E+\infty$ & $0.00 E+\infty$ & $0.00 E+\infty$ \\
\hline 4 & & & & & & & \\
\hline 5 & & & & & & & \\
\hline 6 & & & & & & & \\
\hline
\end{tabular}

\begin{tabular}{c|ccccccc}
$\begin{array}{c}\text { Wind } \\
\text { Speed } \\
\text { Category }\end{array}$ & A & B & C & Non-Fumigation $2 \mathrm{hr}$ Sector-Arc Chi/Q \\
\hline 1 & $8.64 \mathrm{E}-07$ & $8.10 \mathrm{E}-07$ & $8.90 \mathrm{E}-07$ & $1.07 \mathrm{E}-06$ & $2.88 \mathrm{E}-06$ & $8.46 \mathrm{E}-06$ & $0.00 \mathrm{E}+\infty$ \\
2 & $4.02 \mathrm{E}-07$ & $3.60 \mathrm{E}-07$ & $3.70 \mathrm{E}-07$ & $3.81 \mathrm{E}-07$ & $6.76 \mathrm{E}-07$ & $1.13 \mathrm{E}-06$ & $0.00 \mathrm{E}+\infty$ \\
3 & $2.38 \mathrm{E}-07$ & $2.31 \mathrm{E}-07$ & $2.28 \mathrm{E}-07$ & $2.51 \mathrm{E}-07$ & $4.47 \mathrm{E}-07$ & $7.74 \mathrm{E}-07$ & $1.22 \mathrm{E}-06$ \\
4 & $1.65 \mathrm{E}-07$ & $1.56 \mathrm{E}-07$ & $1.69 \mathrm{E}-07$ & $1.83 \mathrm{E}-07$ & $3.29 \mathrm{E}-07$ & $5.82 \mathrm{E}-07$ & $9.27 \mathrm{E}-07$ \\
5 & $1.26 \mathrm{E}-07$ & $0.00 \mathrm{E}+\infty$ & $1.27 \mathrm{E}-07$ & $1.37 \mathrm{E}-07$ & $0.00 \mathrm{E}+\infty$ & $0.00 \mathrm{E}+\infty$ & $0.00 \mathrm{E}+\infty$ \\
6 & $0.00 \mathrm{E}+\infty$ & $0.00 \mathrm{E}+\infty$ & $0.00 \mathrm{E}+\infty$ & $0.00 \mathrm{E}+\infty$ & $0.00 \mathrm{E}+\infty$ & $0.00 \mathrm{E}+\infty$ & $0.00 \mathrm{E}+\infty$
\end{tabular}

\begin{tabular}{|c|c|c|c|c|c|c|c|}
\hline \multirow{2}{*}{$\begin{array}{c}\text { Wind } \\
\text { Speed } \\
\text { Category }\end{array}$} & \multicolumn{7}{|c|}{$\begin{array}{c}\text { Fumigation } 2 \text { hr Sector-Arc Chi/O } \\
\text { Stability Category }\end{array}$} \\
\hline & A & B & C & D & $E$ & $F$ & $G$ \\
\hline 1 & & & & & 1.97E-06 & $3.41 E-06$ & $0.00 \mathrm{E}+\infty 0$ \\
\hline 2 & & & & & $4.64 E-07$ & $454 \mathrm{E}-07$ & $0.00 E+\infty 0$ \\
\hline 3 & & & & & $0.00 E+\infty$ & $0.00 E+\infty 0$ & $0.00 E+00$ \\
\hline 4 & & & & & & $x$ & \\
\hline 5 & & & & & & & \\
\hline 6 & & & & & & & \\
\hline
\end{tabular}


$\begin{array}{llll}\text { SECTOR: NNW } & \text { RELHGT }=50 \quad \text { Terrain }(\mathrm{ft})=154.3 & \text { XDIS }=11870\end{array}$

\begin{tabular}{|c|c|c|c|c|c|c|c|}
\hline \multirow{2}{*}{$\begin{array}{c}\text { Wind } \\
\text { Speed } \\
\text { Category }\end{array}$} & \multicolumn{7}{|c|}{$\begin{array}{l}\text { Joint Freqency Distribution } \\
\text { Stability Category }\end{array}$} \\
\hline & A & B & $\mathrm{C}$ & $\mathrm{D}$ & E & $F$ & G \\
\hline 1 & 0.2638 & 0.0426 & 0.0511 & 0.0454 & 0.0426 & 0.0397 & 0.0000 \\
\hline 2 & 0.4964 & 0.2014 & 0.3461 & 0.6411 & 0.6269 & 0.1305 & 0.0000 \\
\hline 3 & 0.1078 & 0.0738 & 0.2241 & 0.8851 & 1.0297 & 0.2950 & 0.0142 \\
\hline 4 & 0.0142 & 0.0085 & 0.0340 & 0.2525 & 0.0567 & 0.0284 & 0.0028 \\
\hline 5 & 0.0057 & 0.0000 & 0.0113 & 0.0539 & 0.0000 & 0.0000 & 0.0000 \\
\hline 6 & 0.0000 & 0.0000 & 0.0000 & 0.0000 & 0.0000 & 0.0000 & 0.0000 \\
\hline
\end{tabular}

\begin{tabular}{c|ccccccc}
$\begin{array}{c}\text { Wind } \\
\text { Speed } \\
\text { Category }\end{array}$ & A & B & C & D D & E & F & G \\
\hline 1 & $9.18 \mathrm{E}-07$ & $1.14 \mathrm{E}-06$ & $1.66 \mathrm{E}-06$ & $2.82 \mathrm{E}-06$ & $1.07 \mathrm{E}-05$ & $4.56 \mathrm{E}-05$ & $0.00 \mathrm{E}+\infty$ \\
2 & $4.27 \mathrm{E}-07$ & $5.08 \mathrm{E}-07$ & $6.39 \mathrm{E}-07$ & $1.01 \mathrm{E}-06$ & $2.51 \mathrm{E}-\infty 6$ & $6.07 \mathrm{E}-06$ & $0.00 \mathrm{E}+\infty$ \\
3 & $2.53 \mathrm{E}-07$ & $3.27 \mathrm{E}-07$ & $4.24 \mathrm{E}-07$ & $6.63 \mathrm{E}-07$ & $1.66 \mathrm{E}-06$ & $4.17 \mathrm{E}-\infty 6$ & $9.53 \mathrm{E}-\infty 6$ \\
4 & $1.76 \mathrm{E}-07$ & $2.21 \mathrm{E}-07$ & $3.15 \mathrm{E}-07$ & $4.83 \mathrm{E}-07$ & $1.20 \mathrm{E}-\infty 6$ & $3.13 \mathrm{E}-\infty 6$ & $7.23 \mathrm{E}-\infty$ \\
5 & $1.34 \mathrm{E}-07$ & $0.00 \mathrm{E}+\infty$ & $237 \mathrm{E}-07$ & $3.62 \mathrm{E}-07$ & $0.00 \mathrm{E}+\infty$ & $0.00 \mathrm{E}+\infty$ & $0.00 \mathrm{E}+\infty$ \\
6 & $0.00 \mathrm{E}+\infty$ & $0.00 \mathrm{E}+\infty$ & $0.00 \mathrm{E}+\infty$ & $0.00 \mathrm{E}+\infty$ & $0.00 \mathrm{E}+\infty$ & $0.00 \mathrm{E}+\infty$ & $0.00 \mathrm{E}+\infty$
\end{tabular}

\begin{tabular}{|c|c|c|c|c|c|c|c|}
\hline \multirow{2}{*}{$\begin{array}{l}\text { Wind } \\
\text { Speed } \\
\text { Category }\end{array}$} & \multicolumn{7}{|c|}{$\begin{array}{c}2 \text { br Sector-Arc Chi/Q } \\
\text { Stability Category }\end{array}$} \\
\hline & A & B & $\mathrm{C}$ & D & $E$ & $F$ & G \\
\hline 1 & $8.64 \mathrm{E}-07$ & $8.10 \mathrm{E}-07$ & $8.90 \mathrm{E}-07$ & $1.07 \mathrm{E}-06$ & $288 \mathrm{E}-06$ & $8.46 E-06$ & $0.00 \mathrm{E}+\infty$ \\
\hline 2 & $4.02 \mathrm{E}-07$ & $3.60 E-07$ & $3.70 E-07$ & $3.81 E-07$ & $6.76 \mathrm{E}-07$ & $1.13 \mathrm{E}-06$ & $0.00 E+\infty$ \\
\hline 3 & $2.38 \mathrm{E}-07$ & $231 E-07$ & $228 \mathrm{E}-07$ & $2.51 E-07$ & 4.4TE-07 & $7.74 \mathrm{E}-07$ & $1.22 \mathrm{E}-06$ \\
\hline 4 & $1.65 E-07$ & $1.56 E-07$ & $1.69 \mathrm{E}-07$ & $1.83 E-07$ & $329 \mathrm{E}-07$ & $5.82 E-07$ & $9.27 \mathrm{E}-07$ \\
\hline 5 & $1.26 \mathrm{E}-07$ & $0.00 E+\infty$ & $1.27 \mathrm{E}-07$ & 1.3TE-07 & $0.00 \mathrm{E}+\infty 0$ & $0.00 \mathrm{E}+00$ & $0.00 E+\infty$ \\
\hline 6 & $0.00 E \div 00$ & $0.00 \mathrm{E}+\infty 0$ & $0.00 \mathrm{E}+\infty 0$ & $0.00 E+00$ & $0.00 \mathrm{E}+\infty 0$ & $0.00 E+\infty$ & $0.00 \mathrm{E} \div \infty$ \\
\hline
\end{tabular}

\begin{tabular}{|c|c|c|c|c|c|c|c|}
\hline \multirow{2}{*}{$\begin{array}{l}\text { Wind } \\
\text { Speed } \\
\text { Category }\end{array}$} & \multicolumn{7}{|c|}{$\begin{array}{c}\text { Annual Average Sector-Arc Chi/Q } \\
\text { Stability Category }\end{array}$} \\
\hline & A & B & C & D & $E$ & $F$ & $G$ \\
\hline 1 & $9.82 \mathrm{E}-07$ & $9.51 E-07$ & $1.06 \mathrm{E}-06$ & $1.42 \mathrm{E}-06$ & $4.74 \mathrm{E}-06$ & $1.66 \mathrm{E}-05$ & $0.00 E+00$ \\
\hline 2 & 4.57E-07 & $4.22 \mathrm{E}-07$ & $4.42 \mathrm{E}-07$ & $5.09 \mathrm{E}-07$ & $1.11 E-06$ & $222 E-06$ & $0.00 E+\infty$ \\
\hline 3 & $2.70 \mathrm{E}-07$ & $2.71 E-07$ & $2.72 \mathrm{E}-07$ & $3.35 E-07$ & $736 \mathrm{E}-07$ & $1.52 E-06$ & $2.40 \mathrm{E}-06$ \\
\hline 4 & $1.88 \mathrm{E}-07$ & $1.83 E-07$ & $2.02 \mathrm{E}-07$ & $2.44 \mathrm{E}-07$ & $5.41 \mathrm{E}-07$ & $1.14 E-\infty 6$ & $1.82 \mathrm{E}-06$ \\
\hline 5 & $1.44 \mathrm{E}-07$ & $0.00 E+\infty$ & $1.52 \mathrm{E}-07$ & $1.83 \mathrm{E}-07$ & $0.00 \mathrm{E}+\infty$ & $0.00 E+\infty$ & $0.00 E+\infty$ \\
\hline 6 & $0.00 \mathrm{E}+\infty 0$ & $0.00 E+00$ & $0.00 \mathrm{E}+\infty 0$ & $0.00 E+00$ & $0.00 \mathrm{E}+00$ & $0.00 E+\infty$ & $0.00 E+\infty 0$ \\
\hline
\end{tabular}

Annual Average $=4.861 E-08$ (average $X / Q$ weighted by JFD). 


\section{Determination of 99.5 Percentile Relative Concentration}

Sector:

Distance: 11870
Stack / Vent

\begin{tabular}{|r|c|}
\hline $\begin{array}{r}\text { High C.F. } \\
\text { (a) } 0.5248\end{array}$ & $\begin{array}{c}\text { X/Q } \\
\text { (c) } 4.17 \mathrm{E}-6\end{array}$ \\
\hline Low C.F. & (2nd Cat.) \\
(b) 0.2298 & (d) $6.07 \mathrm{E}-6$ \\
\hline
\end{tabular}

$99.5 \% \times / Q \quad 4.33 E-6$

- Interpolation Formula:

$c+((c-d) \cdot(0.5-a) /(a-b))$

Interpolation Factor: (0.5-a)/(a-b)

Interpolation Factor: -0.0841

1st Stab./Speed Cat: $6-2$

2nd Stab./Speed Cat: $6-3$ 
APPENDIX B. 
INHALATION DOSE CALCULATION

\begin{tabular}{|c|c|c|c|c|c|c|c|}
\hline SECTOR: & NNW & RELHGT $=$ & 50 & Terrain $(\mathrm{ft})=$ & 154.3 & XDIS $=$ & 11870 \\
\hline & & Nuclide $=$ & H-3 & & & $\operatorname{ease}(\mathrm{Ci})=$ & $5.00 E+04$ \\
\hline & Decay Consta & at $(1 / \mathrm{sec})=$ & $1.79 E-09$ & & Dose Factor & $\operatorname{em} / u C i)=$ & $9.45 E-05$ \\
\hline & & & & & eathing Rat & $(\mathrm{cu} \mathrm{m} / \mathrm{yr})=$ & $1.20 E+04$ \\
\hline Wind & & & $2 \mathrm{br} \mathrm{Ce}$ & Iterline Dose & mrem) & & \\
\hline Speed & & & & ability Categ & & & \\
\hline Category & A & $\mathrm{B}$ & $\mathrm{C}$ & D & $E$ & $F$ & $\mathrm{G}$ \\
\hline 1 & $1.65 \mathrm{E}+00$ & $2.06 E+\infty 0$ & $2.98 \mathrm{E}+00$ & $5.06 \mathrm{E}+00$ & $1.92 \mathrm{E}+01$ & $8.19 E+01$ & $0.00 \mathrm{E}+\infty 0$ \\
\hline 2 & $7.67 \mathrm{E}-01$ & $9.13 E-01$ & $1.24 E+\infty$ & $1.81 E+00$ & $4.52 E+\infty 0$ & $1.09 \mathrm{E}+01$ & $0.00 \mathrm{E}+\infty 0$ \\
\hline 3 & $4.54 \mathrm{E}-01$ & 5.87E-01 & $7.62 \mathrm{E}-01$ & $1.19 \mathrm{E}+\infty 0$ & $2.99 E+\infty 0$ & $7.49 \mathrm{E}+\infty$ & $1.71 E+01$ \\
\hline 4 & $3.16 \mathrm{E}-01$ & 3.97E-01 & $5.66 \mathrm{E}-01$ & $8.68 E-01$ & $2.20 E+\infty 0$ & $5.63 \mathrm{E}+\infty 0$ & $1.30 \mathrm{E}+01$ \\
\hline 5 & $2.41 E-01$ & $0.00 \mathrm{E}+\infty 0$ & $4.25 \mathrm{E}-01$ & $6.50 \mathrm{E}-01$ & $0.00 \mathrm{E}+00$ & $0.00 \mathrm{E}+\infty 0$ & $0.00 \mathrm{E}+\infty 0$ \\
\hline 6 & $0.00 E \div \infty 0$ & $0.00 E+\infty 0$ & $0.00 \mathrm{E}+\infty 0$ & $0.00 \mathrm{E}+\infty 0$ & $0.00 \mathrm{E}+\infty 0$ & $0.00 \mathrm{E}+\infty 0$ & $0.00 E+\infty$ \\
\hline
\end{tabular}

1st Stab./Speed Cat:: 6-2

2nd Stab./Speed Cat.: $6-3$

Dose: 10.9 (a) Interpolation Factor: -0.0841 (c)

Formula: $b+\left[(b-a)^{*}(c)\right]$

Dose: $\frac{10.99(\mathrm{~b})}{7.49}$

Interpolated Dose: 7.78

\begin{tabular}{c|ccccccc}
$\begin{array}{c}\text { Wind } \\
\text { Speed } \\
\text { Category }\end{array}$ & A & B & C & D & E & F & G \\
\hline 1 & $1.7 \pi \mathrm{E}+\infty$ & $1.71 \mathrm{E}+\infty$ & $1.91 \mathrm{E}+\infty$ & $2.56 \mathrm{E}+\infty$ & $8.51 \mathrm{E}+\infty$ & $2.99 \mathrm{E}+01$ & $0.00 \mathrm{E}+\infty$ \\
2 & $8.21 \mathrm{E}-01$ & $7.59 \mathrm{E}-01$ & $7.94 \mathrm{E}-01$ & $9.14 \mathrm{E}-01$ & $2.00 \mathrm{E}+\infty$ & $3.98 \mathrm{E}+\infty$ & $0.00 \mathrm{E}+\infty$ \\
3 & $4.86 \mathrm{E}-01$ & $4.88 \mathrm{E}-01$ & $4.89 \mathrm{E}-01$ & $6.02 \mathrm{E}-01$ & $1.32 \mathrm{E}+\infty$ & $2.74 \mathrm{E}+\infty$ & $4.31 \mathrm{E}+\infty$ \\
4 & $3.38 \mathrm{E}-01$ & $3.30 \mathrm{E}-01$ & $3.63 \mathrm{E}-01$ & $4.38 \mathrm{E}-01$ & $9.73 \mathrm{E}-01$ & $2.06 \mathrm{E}+\infty$ & $3.28 \mathrm{E}+\infty$ \\
5 & $2.58 \mathrm{E}-01$ & $0.00 \mathrm{E}+\infty$ & $2.73 \mathrm{E}-01$ & $3.29 \mathrm{E}-01$ & $0.00 \mathrm{E}+\infty$ & $0.00 \mathrm{E}+\infty$ & $0.00 \mathrm{E}+\infty$ \\
6 & $0.00 \mathrm{E}+\infty$ & $0.00 \mathrm{E}+\infty$ & $0.00 \mathrm{E}+\infty$ & $0.00 \mathrm{E}+\infty$ & $0.00 \mathrm{E}+\infty$ & $0.00 \mathrm{E}+\infty$ & $0.00 \mathrm{E}+\infty$
\end{tabular}

Annual Average $=8.736 \mathrm{E}-02$ (average dose weighted by JFD). 
INHALATION DOSE CALCULATION

$$
\begin{aligned}
& \text { SECTOR: NNW RELHGT }=50 \quad \text { Terrain }(\mathrm{ft})=154.3 \quad \text { XDIS }=11870 \\
& \text { Nuclide }=\text { Be-7 } \\
& \text { Decay Constant }(1 / \mathrm{sec})=1.50 \mathrm{E}-07
\end{aligned}
$$

\begin{tabular}{c|ccccccc}
$\begin{array}{c}\text { Wind } \\
\text { Speed } \\
\text { Category }\end{array}$ & A & B & C & Stability Category \\
\hline 1 & $9.42 \mathrm{E}-05$ & $1.17 \mathrm{E}-04$ & $1.70 \mathrm{E}-04$ & $2.89 \mathrm{E}-04$ & $1.10 \mathrm{E}-03$ & $4.66 \mathrm{E}-03$ & $0.00 \mathrm{E}+00$ \\
2 & $4.38 \mathrm{E}-05$ & $5.22 \mathrm{E}-05$ & $7.07 \mathrm{E}-05$ & $1.03 \mathrm{E}-04$ & $2.58 \mathrm{E}-04$ & $6.23 \mathrm{E}-04$ & $0.00 \mathrm{E}+\infty$ \\
3 & $2.59 \mathrm{E}-05$ & $3.35 \mathrm{E}-05$ & $4.35 \mathrm{E}-05$ & $6.81 \mathrm{E}-05$ & $1.71 \mathrm{E}-04$ & $4.28 \mathrm{E}-04$ & $9.78 \mathrm{E}-04$ \\
4 & $1.80 \mathrm{E}-05$ & $2.27 \mathrm{E}-05$ & $3.24 \mathrm{E}-05$ & $4.96 \mathrm{E}-05$ & $1.25 \mathrm{E}-04$ & $3.22 \mathrm{E}-04$ & $7.43 \mathrm{E}-04$ \\
5 & $1.38 \mathrm{E}-05$ & $0.00 \mathrm{E}+00$ & $2.43 \mathrm{E}-05$ & $3.72 \mathrm{E}-05$ & $0.00 \mathrm{E}+\infty$ & $0.00 \mathrm{E}+\infty 0$ & $0.00 \mathrm{E}+\infty$ \\
6 & $0.00 \mathrm{E}+00$ & $0.00 \mathrm{E}+\infty$ & $0.00 \mathrm{E}+00$ & $0.00 \mathrm{E}+\infty$ & $0.00 \mathrm{E}+\infty$ & $0.00 \mathrm{E}+\infty$ & $0.00 \mathrm{E}+\infty$
\end{tabular}

1st Stab./Speed Cat:: $6-2$

2nd Stab./Speed Cat.: $6-3$

Formula: $b+\left[(b-a)^{*}(c)\right]$
Dose: $6.23 E-4(a) \quad$ Interpolation Factor: -0.084 (c) Dose: $4.28 E-4(\mathrm{~b})$

Interpolated Dose: $4.44 \mathrm{E}-4$

\begin{tabular}{c|ccccccc}
$\begin{array}{c}\text { Wind } \\
\text { Speed } \\
\text { Category }\end{array}$ & A & B & C & D & E & F & G \\
\hline 1 & $1.01 E-04$ & $9.75 E-05$ & $1.09 E-04$ & $1.46 \mathrm{E}-04$ & $4.84 \mathrm{E}-04$ & $1.69 \mathrm{E}-03$ & $0.00 \mathrm{E}+\infty$ \\
2 & $4.69 \mathrm{E}-05$ & $4.33 \mathrm{E}-05$ & $4.53 \mathrm{E}-05$ & $522 \mathrm{E}-05$ & $1.14 \mathrm{E}-04$ & $2.27 \mathrm{E}-04$ & $0.00 \mathrm{E}+\infty$ \\
3 & $2.7 \mathrm{E}-05$ & $2.79 \mathrm{E}-05$ & $2.79 \mathrm{E}-05$ & $3.44 \mathrm{E}-05$ & $7.55 \mathrm{E}-05$ & $1.56 \mathrm{E}-04$ & $2.46 \mathrm{E}-04$ \\
4 & $1.93 \mathrm{E}-05$ & $1.88 \mathrm{E}-05$ & $2.07 \mathrm{E}-05$ & $2.50 \mathrm{E}-05$ & $5.56 \mathrm{E}-05$ & $1.17 \mathrm{E}-04$ & $1.87 \mathrm{E}-04$ \\
5 & $1.47 \mathrm{E}-05$ & $0.00 \mathrm{E}+\infty$ & $1.56 \mathrm{E}-05$ & $1.88 \mathrm{E}-05$ & $0.00 \mathrm{E}+\infty$ & $0.00 \mathrm{E}+\infty$ & $0.00 \mathrm{E}+\infty$ \\
6 & $0.00 \mathrm{E}+00$ & $0.00 \mathrm{E}+\infty$ & $0.00 \mathrm{E}+\infty$ & $0.00 \mathrm{E}+\infty$ & $0.00 \mathrm{E}+\infty$ & $0.00 \mathrm{E}+\infty$ & $0.00 \mathrm{E}+\infty$
\end{tabular}

Annual Average $=4.982 E-06 \quad$ (average dose weighted by JFD). 
INHALATION DOSE CALCULATION

\begin{tabular}{|c|c|c|c|c|c|c|c|}
\hline SECTOR: & NNW & RELHGT $=$ & & Terrain $(\mathrm{ft})=$ & 54.3 & XDIS $=$ & 11870 \\
\hline & & Nuclide $=$ & C-14 & & & $\operatorname{ease}(\mathrm{Ci})=$ & $5.00 \mathrm{E}+\infty$ \\
\hline & Decay Consta & nt $(1 / \sec )=$ & $3.86 \mathrm{E}-09$ & & Dose Factor & $\mathrm{em} / \mathrm{uCi})=$ & $2.40 \mathrm{E}-05$ \\
\hline Wind & & & $2 \mathrm{hr} \mathrm{Ce}$ & terline Dose & mrem) & & \\
\hline Speed & & & & bility Categ & & & \\
\hline Category & A & B & C & D & $E$ & $F$ & $G$ \\
\hline 1 & $4.19 E-05$ & $5.22 \mathrm{E}-05$ & $7.5 T E-05$ & $1.29 \mathrm{E}-04$ & $4.88 \mathrm{E}-04$ & $2.08 \mathrm{E}-03$ & $0.00 \mathrm{E}+00$ \\
\hline 2 & $1.95 \mathrm{E}-05$ & $232 E-05$ & $3.14 E-05$ & $4.59 \mathrm{E}-05$ & 1.15E-04 & $2 \pi 7 E-04$ & $0.00 \mathrm{E}+\infty 0$ \\
\hline 3 & $1.15 \mathrm{E}-05$ & $1.49 \mathrm{E}-05$ & $1.93 \mathrm{E}-05$ & $3.03 \mathrm{E}-05$ & $758 \mathrm{E}-0.05$ & $1.90 \mathrm{E}-04$ & $4.35 \mathrm{E}-04$ \\
\hline 4 & $8.01 E-06$ & $1.01 E-05$ & $1.44 E-05$ & $2.20 \mathrm{E}-05$ & $5.58 \mathrm{E}-05$ & $1.43 E-04$ & $3.30 \mathrm{E}-04$ \\
\hline 5 & $6.13 E-06$ & $0.00 \mathrm{E}+\infty 0$ & $1.08 \mathrm{E}-05$ & $1.65 \mathrm{E}-05$ & $0.00 \mathrm{E}+\infty 0$ & $0.00 \mathrm{E}+\infty$ & $0.00 \mathrm{E}+\infty$ \\
\hline 6 & $0.00 \mathrm{E}+\infty$ & $0.00 \mathrm{E}+\infty 0$ & $0.00 \mathrm{E}+\infty 0$ & $0.00 \mathrm{E}+\infty 0$ & $0.00 \mathrm{E}+\infty 0$ & $0.00 \mathrm{E}+00$ & $0.00 E+\infty$ \\
\hline
\end{tabular}

1st Stab./Speed Cat.: $6-2$

2nd Stab./Speed Cat.:

Dose:2.77E-4(a) Interpolation Factor: $-0.0841(\mathrm{c})$ Dose: $1.90 E-4(b)$

Formula: $b+\left[(b-a)^{*}(c)\right]$

Interpolated Dose: $1.97 \mathrm{E}-4$

\begin{tabular}{c|ccccccc}
$\begin{array}{c}\text { Wind } \\
\text { Speed } \\
\text { Category }\end{array}$ & A & B & C & D & E & F & G \\
\hline 1 & $4.48 \mathrm{E}-05$ & $4.34 \mathrm{E}-05$ & $4.85 \mathrm{E}-05$ & $6.50 \mathrm{E}-05$ & $2.16 \mathrm{E}-04$ & $7.60 \mathrm{E}-04$ & $0.00 \mathrm{E}+00$ \\
2 & $2.09 \mathrm{E}-05$ & $1.93 \mathrm{E}-05$ & $2.02 \mathrm{E}-05$ & $2.32 \mathrm{E}-05$ & $5.09 \mathrm{E}-05$ & $1.01 \mathrm{E}-04$ & $0.00 \mathrm{E}+00$ \\
3 & $1.23 \mathrm{E}-05$ & $1.24 \mathrm{E}-05$ & $1.24 \mathrm{E}-05$ & $1.53 \mathrm{E}-05$ & $3.36 \mathrm{E}-05$ & $6.95 \mathrm{E}-05$ & $1.10 \mathrm{E}-04$ \\
4 & $8.57 \mathrm{E}-06$ & $8.37 \mathrm{E}-06$ & $9.22 \mathrm{E}-06$ & $1.11 \mathrm{E}-05$ & $2.47 \mathrm{E}-05$ & $5.22 \mathrm{E}-05$ & $8.32 \mathrm{E}-05$ \\
5 & $6.56 \mathrm{E}-06$ & $0.00 \mathrm{E}+\infty$ & $6.92 \mathrm{E}-06$ & $8.35 \mathrm{E}-06$ & $0.00 \mathrm{E}+\infty$ & $0.00 \mathrm{E}+\infty$ & $0.00 \mathrm{E}+\infty$ \\
6 & $0.00 \mathrm{E}+00$ & $0.00 \mathrm{E}+\infty$ & $0.00 \mathrm{E}+\infty$ & $0.00 \mathrm{E}+\infty$ & $0.00 \mathrm{E}+\infty$ & $0.00 \mathrm{E}+\infty$ & $0.00 \mathrm{E}+\infty$
\end{tabular}

Annual Average $=2.219 \mathrm{E}-06$ (average dose weighted by JFD). 


\section{INHALATION DOSE CALCULATION}

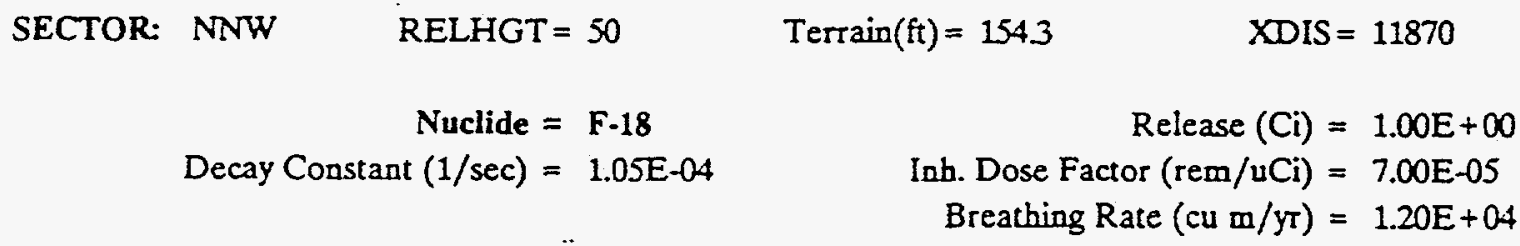

\begin{tabular}{c|ccccccc}
$\begin{array}{c}\text { Wind } \\
\text { Speed } \\
\text { Category }\end{array}$ & A & B & C & D hr Centerline Dose (mrem) \\
Stability Category & D & E & F & G \\
\hline 1 & $8.94 \mathrm{E}-06$ & $1.19 \mathrm{E}-05$ & $1.56 \mathrm{E}-05$ & $2.41 \mathrm{E}-05$ & $4.93 \mathrm{E}-05$ & $5.86 \mathrm{E}-05$ & $0.00 \mathrm{E}+00$ \\
2 & $7.12 \mathrm{E}-06$ & $8.90 \mathrm{E}-06$ & $1.19 \mathrm{E}-05$ & $1.78 \mathrm{E}-05$ & $4.43 \mathrm{E}-05$ & $1.08 \mathrm{E}-04$ & $0.00 \mathrm{E}+\infty$ \\
3 & $5.10 \mathrm{E}-06$ & $6.64 \mathrm{E}-06$ & $8.66 \mathrm{E}-06$ & $1.35 \mathrm{E}-05$ & $3.37 \mathrm{E}-05$ & $8.41 \mathrm{E}-05$ & $1.96 \mathrm{E}-04$ \\
4 & $3.86 \mathrm{E}-06$ & $4.90 \mathrm{E}-06$ & $6.89 \mathrm{E}-06$ & $1.06 \mathrm{E}-05$ & $2.66 \mathrm{E}-05$ & $6.77 \mathrm{E}-05$ & $1.58 \mathrm{E}-04$ \\
5 & $3.08 \mathrm{E}-06$ & $0.00 \mathrm{E}+\infty$ & $5.43 \mathrm{E}-06$ & $8.33 \mathrm{E}-06$ & $0.00 \mathrm{E}+\infty 0$ & $0.00 \mathrm{E}+\infty$ & $0.00 \mathrm{E}+\infty$ \\
6 & $0.00 \mathrm{E}+\infty$ & $0.00 \mathrm{E}+0$ & $0.00 \mathrm{E}+00$ & $0.00 \mathrm{E}+\infty$ & $0.00 \mathrm{E}+\infty$ & $0.00 \mathrm{E}+\infty$ & $0.00 \mathrm{E}+\infty$
\end{tabular}

1st Stab./Speed Cat.:

2nd Stab./Speed Cat::
Dose: $\underline{1.08 E-4(a)}$ Interpolation Factor: $-0.0841(\mathrm{c})$ Dose: $8.41 \mathrm{E}-5(\mathrm{~b})$

Formula: $b+\left[(b-a)^{*}(c)\right]$

Interpolated Dose:

$8.61 E-5$

\begin{tabular}{c|ccccccc}
$\begin{array}{c}\text { Wind } \\
\text { Speed } \\
\text { Category }\end{array}$ & A & B & C & D & E & F & G \\
\hline 1 & $8.33 E-06$ & $8.36 \mathrm{E}-06$ & $8.20 \mathrm{E}-06$ & $8.30 \mathrm{E}-06$ & $7.03 \mathrm{E}-06$ & $1.14 \mathrm{E}-06$ & $0.00 \mathrm{E}+00$ \\
2 & $7.14 \mathrm{E}-06$ & $6.88 \mathrm{E}-06$ & $7.03 \mathrm{E}-06$ & $7.87 \mathrm{E}-06$ & $1.50 \mathrm{E}-05$ & $2.67 \mathrm{E}-05$ & $0.00 \mathrm{E}+\infty$ \\
3 & $5.25 \mathrm{E}-06$ & $5.27 \mathrm{E}-06$ & $5.27 \mathrm{E}-06$ & $6.24 \mathrm{E}-06$ & $1.25 \mathrm{E}-05$ & $2.35 \mathrm{E}-05$ & $3.85 \mathrm{E}-05$ \\
4 & $4.02 \mathrm{E}-06$ & $3.94 \mathrm{E}-06$ & $4.25 \mathrm{E}-06$ & $5.01 \mathrm{E}-06$ & $1.04 \mathrm{E}-05$ & $2.02 \mathrm{E}-05$ & $3.30 \mathrm{E}-05$ \\
5 & $3.23 \mathrm{E}-06$ & $0.00 \mathrm{E}+\infty$ & $3.38 \mathrm{E}-06$ & $4.01 \mathrm{E}-06$ & $0.00 \mathrm{E}+\infty$ & $0.00 \mathrm{E}+\infty$ & $0.00 \mathrm{E}+\infty$ \\
6 & $0.00 \mathrm{E}+\infty$ & $0.00 \mathrm{E}+\infty$ & $0.00 \mathrm{E}+00$ & $0.00 \mathrm{E}+\infty$ & $0.00 \mathrm{E}+\infty$ & $0.00 \mathrm{E}+\infty$ & $0.00 \mathrm{E}+\infty$
\end{tabular}

Annual Average $=6.007 E-07$ (average dose weighted by JFD). 


\section{INHALATION DOSE CALCULATION}

$$
\begin{aligned}
& \text { SECTOR: NNW RELHGT }=50 \quad \text { Terrain }(\mathrm{ft})=154.3 \quad \text { XDIS }=11870 \\
& \text { Nuclide }=1-135 \quad \text { Release }(\mathrm{Ci})=5.00 \mathrm{E}+00 \\
& \text { Decay Constant }(1 / \mathrm{sec})=2.92 \mathrm{E}-05 \quad \text { Inh. Dose Factor }(\mathrm{rem} / \mathrm{uCi})=1.10 \mathrm{E}-03 \\
& \text { Breathing Rate }(\mathrm{cu} \mathrm{m} / \mathrm{yr})=1.20 \mathrm{E}+04
\end{aligned}
$$

\begin{tabular}{|c|c|c|c|c|c|c|c|}
\hline \multirow{2}{*}{$\begin{array}{l}\text { Wind } \\
\text { Speed } \\
\text { Category }\end{array}$} & \multicolumn{7}{|c|}{$\begin{array}{c}2 \text { hr Centerline Dose (mrem) } \\
\text { Stability Category }\end{array}$} \\
\hline & A & B & C & D & $\mathrm{E}$ & $F$ & G \\
\hline 1 & $1.45 \mathrm{E}-03$ & $1.84 \mathrm{E}-03$ & $260 E-03$ & $4.29 E-03$ & $1.37 \mathrm{E}-02$ & $4.11 E-02$ & $0.00 \mathrm{E}+00$ \\
\hline 2 & $7.84 \mathrm{E}-04$ & $9.46 \mathrm{E}-04$ & $1.28 \mathrm{E}-03$ & $1.88 \mathrm{E}-03$ & $4.69 \mathrm{E}-03$ & $1.14 \mathrm{E}-02$ & $0.00 E+\infty$ \\
\hline 3 & $4.89 E-04$ & 6.34E-04 & 8.24E-04 & $1.29 \mathrm{E}-03$ & $3.22 E-03$ & $8.08 \mathrm{E}-03$ & $1.86 \mathrm{E}-02$ \\
\hline 4 & $3.48 \mathrm{E}-04$ & $4.39 E-04$ & $6.24 \mathrm{E}-04$ & $9.57 \mathrm{E}-04$ & $2.42 E-03$ & $6.18 \mathrm{E}-03$ & $1.43 \mathrm{E}-02$ \\
\hline 5 & $2.70 \mathrm{E}-0.4$ & $0.00 \mathrm{E}+\infty 0$ & 4.75E-04 & $7.27 \mathrm{E}-04$ & $0.00 \mathrm{E}+00$ & $0.00 \mathrm{E}+\infty 0$ & $0.00 \mathrm{E}+\infty 0$ \\
\hline 6 & $0.00 \mathrm{E}+\infty 0$ & $0.00 \mathrm{E}+00$ & $0.00 \mathrm{E}+\infty 0$ & $0.00 E+\infty$ & $0.00 \mathrm{E}+00$ & $0.00 E+\infty$ & $0.00 \mathrm{E}+00$ \\
\hline
\end{tabular}

Stab./Speed Cat:: $6-2$

Stab./Speed Cat:: $6-3$

Formula: $b+\left[(b-a)^{*}(c)\right]$
Dose: $1.14 \mathrm{E}-2$ (a) Interpolation Factor: -0.0841 (c) Doses $\overline{.08 E-3(b)}$

Interpolated Dose: $8.36 E-3$

\begin{tabular}{c|ccccccc}
$\begin{array}{c}\text { Wind } \\
\text { Speed } \\
\text { Category }\end{array}$ & A & B & C & D & E & F & G \\
\hline 1 & $1.50 \mathrm{E}-03$ & $1.46 \mathrm{E}-03$ & $1.58 \mathrm{E}-03$ & $1.95 \mathrm{E}-03$ & $4.44 \mathrm{E}-03$ & $6.64 \mathrm{E}-03$ & $0.00 \mathrm{E}+00$ \\
2 & $8.24 \mathrm{E}-04$ & $7.71 \mathrm{E}-04$ & $8.01 \mathrm{E}-04$ & $9.15 \mathrm{E}-04$ & $1.93 \mathrm{E}-03$ & $3.72 \mathrm{E}-03$ & $0.00 \mathrm{E}+\infty$ \\
3 & $5.18 \mathrm{E}-04$ & $5.20 \mathrm{E}-04$ & $5.21 \mathrm{E}-04$ & $6.35 \mathrm{E}-04$ & $1.36 \mathrm{E}-03$ & $2.74 \mathrm{E}-03$ & $4.36 \mathrm{E}-03$ \\
4 & $3.70 \mathrm{E}-04$ & $3.62 \mathrm{E}-04$ & $3.96 \mathrm{E}-04$ & $4.75 \mathrm{E}-04$ & $1.03 \mathrm{E}-03$ & $2.13 \mathrm{E}-03$ & $3.43 \mathrm{E}-03$ \\
5 & $2.87 \mathrm{E}-04$ & $0.00 \mathrm{E}+\infty$ & $3.02 \mathrm{E}-04$ & $3.62 \mathrm{E}-04$ & $0.00 \mathrm{E}+\infty$ & $0.00 \mathrm{E}+\infty$ & $0.00 \mathrm{E}+\infty$ \\
6 & $0.00 \mathrm{E}+\infty$ & $0.00 \mathrm{E}+\infty$ & $0.00 \mathrm{E}+\infty$ & $0.00 \mathrm{E}+\infty$ & $0.00 \mathrm{E}+\infty$ & $0.00 \mathrm{E}+\infty$ & $0.00 \mathrm{E}+\infty$
\end{tabular}

Annual Average $=7.538 \mathrm{E}-05 \quad$ (average dose weighted by JFD) . 
SECTOR: WNW RELHGT $=50 \quad$ Terrain $(\mathrm{ft})=111 \quad$ XDIS $=12068$

\begin{tabular}{c|ccccccc}
$\begin{array}{c}\text { Wind } \\
\text { Speed } \\
\text { Category }\end{array}$ & \multicolumn{7}{|c}{$\begin{array}{c}\text { Joint Frequency Distribution } \\
\text { Stability Category }\end{array}$} \\
\hline 1 & A & B & C & D & E & F & G \\
\hline 2 & 0.2326 & 0.0567 & 0.0454 & 0.0340 & 0.0227 & 0.0000 & 0.0000 \\
3 & 0.5872 & 0.2780 & 0.3801 & 0.6127 & 0.4227 & 0.0766 & 0.0028 \\
4 & 0.1418 & 0.1362 & 0.2411 & 0.5220 & 0.5673 & 0.1759 & 0.0057 \\
5 & 0.0028 & 0.0113 & 0.0312 & 0.1475 & 0.0567 & 0.0369 & 0.0028 \\
6 & 0.0000 & 0.0000 & 0.0000 & 0.0142 & 0.0057 & 0.0000 & 0.0000 \\
& 0.0000 & 0.0000 & 0.0000 & 0.0000 & 0.0000 & 0.0000 & 0.0000
\end{tabular}

\begin{tabular}{c|ccccccc}
$\begin{array}{c}\text { Wind } \\
\text { Speed } \\
\text { Category }\end{array}$ & A & B & C & $\begin{array}{c}2 \text { hr Centerline Chi/Q } \\
\text { Stability Category } \\
\text { D }\end{array}$ & E & $F$ & G \\
\hline 1 & $8.86 \mathrm{E}-07$ & $1.11 \mathrm{E}-06$ & $1.28 \mathrm{E}-06$ & $1.83 \mathrm{E}-06$ & $4.41 \mathrm{E}-06$ & $0.00 \mathrm{E}+\infty 0$ & $0.00 \mathrm{E}+\infty$ \\
2 & $4.05 \mathrm{E}-07$ & $5.17 \mathrm{E}-07$ & $6.84 \mathrm{E}-07$ & $1.02 \mathrm{E}-06$ & $2.42 \mathrm{E}-06$ & $5.63 \mathrm{E}-06$ & $1.62 \mathrm{E}-05$ \\
3 & $2.53 \mathrm{E}-07$ & $3.35 \mathrm{E}-07$ & $4.23 \mathrm{E}-07$ & $6.56 \mathrm{E}-07$ & $1.64 \mathrm{E}-06$ & $3.76 \mathrm{E}-06$ & $8.06 \mathrm{E}-06$ \\
4 & $1.86 \mathrm{E}-07$ & $2.29 \mathrm{E}-07$ & $3.11 \mathrm{E}-07$ & $4.67 \mathrm{E}-07$ & $1.20 \mathrm{E}-06$ & $3.05 \mathrm{E}-06$ & $6.50 \mathrm{E}-06$ \\
5 & $0.00 \mathrm{E}+\infty$ & $0.00 \mathrm{E}+\infty$ & $0.00 \mathrm{E}+\infty$ & $3.54 \mathrm{E}-07$ & $9.50 \mathrm{E}-07$ & $0.00 \mathrm{E}+\infty$ & $0.00 \mathrm{E}+\infty$ \\
6 & $0.00 \mathrm{E}+\infty$ & $0.00 \mathrm{E}+\infty$ & $0.00 \mathrm{E}+\infty$ & $0.00 \mathrm{E}+00$ & $0.00 \mathrm{E}+\infty$ & $0.00 \mathrm{E}+\infty$ & $0.00 \mathrm{E}+\infty$
\end{tabular}

\begin{tabular}{c|ccccccc}
$\begin{array}{c}\text { Wind } \\
\text { Speed } \\
\text { Category }\end{array}$ & A & B & C & $\begin{array}{c}2 \text { hr Sector-Arc Chi/Q } \\
\text { Stability Category } \\
\text { D }\end{array}$ & E & F & $G$ \\
\hline 1 & $8.32 \mathrm{E}-07$ & $7.81 \mathrm{E}-07$ & $6.87 \mathrm{E}-07$ & $6.92 \mathrm{E}-07$ & $1.18 \mathrm{E}-06$ & $0.00 \mathrm{E}+\infty$ & $0.00 \mathrm{E}+\infty$ \\
2 & $3.80 \mathrm{E}-07$ & $3.65 \mathrm{E}-07$ & $3.67 \mathrm{E}-07$ & $3.84 \mathrm{E}-07$ & $6.51 \mathrm{E}-07$ & $1.04 \mathrm{E}-06$ & $2.07 \mathrm{E}-06$ \\
3 & $2.37 \mathrm{E}-07$ & $2.37 \mathrm{E}-07$ & $2.27 \mathrm{E}-07$ & $2.48 \mathrm{E}-07$ & $4.41 \mathrm{E}-07$ & $6.98 \mathrm{E}-07$ & $1.03 \mathrm{E}-06$ \\
4 & $1.75 \mathrm{E}-07$ & $1.62 \mathrm{E}-07$ & $1.67 \mathrm{E}-07$ & $1.76 \mathrm{E}-07$ & $3.23 \mathrm{E}-07$ & $5.66 \mathrm{E}-07$ & $8.32 \mathrm{E}-07$ \\
5 & $0.00 \mathrm{E}+\infty$ & $0.00 \mathrm{E}+\infty$ & $0.00 \mathrm{E}+\infty$ & $134 \mathrm{E}-07$ & $2.55 \mathrm{E}-07$ & $0.00 \mathrm{E}+\infty$ & $0.00 \mathrm{E}+\infty$ \\
6 & $0.00 \mathrm{E}+\infty$ & $0.00 \mathrm{E}+\infty$ & $0.00 \mathrm{E}+\infty$ & $0.00 \mathrm{E}+\infty$ & $0.00 \mathrm{E}+\infty$ & $0.00 \mathrm{E}+\infty$ & $0.00 \mathrm{E}+\infty$
\end{tabular}

\begin{tabular}{c|ccccccc}
$\begin{array}{c}\text { Wind } \\
\text { Speed } \\
\text { Category }\end{array}$ & A & B & C & Annual Average Sector-Arc Chi/Q \\
Stability Category \\
\hline 1 & $9.11 \mathrm{E}-07$ & $8.74 \mathrm{E}-07$ & $7.78 \mathrm{E}-07$ & $8.48 \mathrm{E}-07$ & $1.68 \mathrm{E}-06$ & $0.00 \mathrm{E}+\infty$ & $0.00 \mathrm{E}+\infty 0$ \\
2 & $4.16 \mathrm{E}-07$ & $4.09 \mathrm{E}-07$ & $4.16 \mathrm{E}-07$ & $4.71 \mathrm{E}-07$ & $9.24 \mathrm{E}-07$ & $1.68 \mathrm{E}-\infty 6$ & $3.33 \mathrm{E}-06$ \\
3 & $2.60 \mathrm{E}-07$ & $2.65 \mathrm{E}-07$ & $257 \mathrm{E}-07$ & $3.04 \mathrm{E}-07$ & $6.26 \mathrm{E}-07$ & $1.12 \mathrm{E}-06$ & $1.66 \mathrm{E}-06$ \\
4 & $1.91 \mathrm{E}-07$ & $1.81 \mathrm{E}-07$ & $1.89 \mathrm{E}-07$ & $2.16 \mathrm{E}-07$ & $4.58 \mathrm{E}-07$ & $9.09 \mathrm{E}-07$ & $1.34 \mathrm{E}-06$ \\
5 & $0.00 \mathrm{E}+\infty$ & $0.00 \mathrm{E}+\infty$ & $0.00 \mathrm{E}+\infty$ & $1.64 \mathrm{E}-07$ & $3.62 \mathrm{E}-07$ & $0.00 \mathrm{E}+\infty$ & $0.00 \mathrm{E}+\infty$ \\
6 & $0.00 \mathrm{E}+\infty$ & $0.00 \mathrm{E}+\infty$ & $0.00 \mathrm{E}+\infty$ & $0.00 \mathrm{E}+\infty$ & $0.00 \mathrm{E}+\infty$ & $0.00 \mathrm{E}+\infty$ & $0.00 \mathrm{E}+\infty$
\end{tabular}

Annual Average $=2.660 \mathrm{E}-08$ (average $\mathrm{X} / \mathrm{Q}$ weighted by JFD). 
Determination of 99.5 Percentile Relative Concentration

Sector: WNW

Distance: $\overline{12068(7.5 \mathrm{mi})}$

\begin{tabular}{|l|l|l|}
\hline Ordered X/Q & \multicolumn{1}{|c|}{ Freq. } & Cum. Freq. \\
\hline $2.07 \mathrm{E}-6$ & 0.0028 & 0.0028 \\
\hline $1.18 \mathrm{E}-6$ & 0.0227 & 0.0255 \\
\hline $1.04 \mathrm{E}-6$ & 0.0766 & 0.1021 \\
\hline $1.03 \mathrm{E}-6$ & 0.0057 & 0.1078 \\
\hline $8.32 \mathrm{E}-7$ & 0.2326 & 0.3404 \\
\hline $8.32 \mathrm{E}-7$ & 0.0028 & 0.3432 \\
\hline $7.81 \mathrm{E}-7$ & 0.0567 & 0.3999 \\
\hline $6.98 \mathrm{E}-07$ & 0.1759 & 0.5758 \\
\hline & & \\
\hline & & \\
\hline & & \\
\hline & & \\
\hline
\end{tabular}

Stack / Vent

\begin{tabular}{|r|c|}
\hline $\begin{array}{r}\text { High C.F. } \\
\text { (a) } 0.5758\end{array}$ & $\begin{array}{c}\text { X/Q } \\
\text { (c) } 6.98 \mathrm{E}-7\end{array}$ \\
\hline Low C.F. & X/Q \\
(b) 0.3999 & (d) $7.81 \mathrm{E}-7$ \\
\hline
\end{tabular}

$99.5 \% \mathrm{X} / \mathrm{Q} 7.34 \mathrm{E}-7$

- Interpolation Formula:

$c+((c-d) \cdot(0.5-a) /(a-b))$

Interpolation Factor: (0.5-a)/(a-b)

Interpolation Factor: -0.4309

1st Stab./Speed Cat: $2-1$

2nd Stab./Speed Cat: $6-3$ 


\section{RELATIVE AIR CONCENTRATION}

SECTOR: WNW RELHGT $=50 \quad$ Terrain $(\mathrm{ft})=144 \quad$ XDIS $=24135$

\begin{tabular}{|c|c|c|c|c|c|c|c|}
\hline \multirow{2}{*}{$\begin{array}{c}\text { Wind } \\
\text { Speed } \\
\text { Category }\end{array}$} & \multicolumn{7}{|c|}{$\begin{array}{c}\text { Joint Freqency Distribution } \\
\text { Stability Category }\end{array}$} \\
\hline & $\mathrm{A}$ & $\mathrm{B}$ & C & $\mathrm{D}$ & $E$ & $F$ & $G$ \\
\hline 1 & 0.2326 & 0.0567 & 0.0454 & 0.0340 & 0.0227 & 0.0000 & 0.0000 \\
\hline 2 & 0.5872 & 0.2780 & 0.3801 & 0.6127 & 0.4227 & 0.0766 & 0.0028 \\
\hline 3 & 0.1418 & 0.1362 & 0.2411 & 0.5220 & 0.5673 & 0.1759 & 0.0057 \\
\hline 4 & 0.0028 & 0.0113 & 0.0312 & 0.1475 & 0.0567 & 0.0369 & 0.0028 \\
\hline 5 & 0.0000 & 0.0000 & 0.0000 & 0.0142 & 0.0057 & 0.0000 & 0.0000 \\
\hline 6 & 0.0000 & 0.0000 & 0.0000 & 0.0000 & 0.0000 & 0.0000 & 0.0000 \\
\hline
\end{tabular}

\begin{tabular}{|c|c|c|c|c|c|c|c|}
\hline \multirow{2}{*}{$\begin{array}{c}\text { Wind } \\
\text { Speed } \\
\text { Category }\end{array}$} & \multicolumn{7}{|c|}{$\begin{array}{c}2 \text { hr Centerline Chi/Q } \\
\text { Stability Category }\end{array}$} \\
\hline & A & $\mathrm{B}$ & $\mathrm{C}$ & D & $\mathrm{E}$ & $\mathrm{F}$ & G \\
\hline 1 & $4.76 \mathrm{E}-07$ & $5.94 \mathrm{E}-07$ & $6.88 \mathrm{E}-07$ & $9.10 \mathrm{E}-07$ & $1.80 E-06$ & $0.00 \mathrm{E}+\infty 0$ & $0.00 E+\infty$ \\
\hline 2 & $2.18 \mathrm{E}-07$ & $278 E-07$ & $3.68 \mathrm{E}-07$ & $5.06 \mathrm{E}-07$ & $9.91 E-07$ & $250 \mathrm{E}-06$ & $830 E-06$ \\
\hline 3 & $136 \mathrm{E}-07$ & $1.80 \mathrm{E}-07$ & $227 \mathrm{E}-07$ & $3.26 \mathrm{E}-07$ & $6.72 E-07$ & $1.67 \mathrm{E}-06$ & $4.13 E-06$ \\
\hline 4 & $9.98 E-08$ & $1.23 \mathrm{E}-07$ & $1.67 \mathrm{E}-07$ & $232 \mathrm{E}-07$ & $4.92 \mathrm{E}-07$ & $136 \mathrm{E}-\infty 6$ & $3.33 E-06$ \\
\hline 5 & $0.00 \mathrm{E}+\infty 0$ & $0.00 E+\infty$ & $0.00 E+\infty$ & $1.76 \mathrm{E}-07$ & $3.88 \mathrm{E}-07$ & $0.00 E+\infty 0$ & $0.00 \mathrm{E}+\infty$ \\
\hline 6 & $0.00 \mathrm{E}+\infty 0$ & $0.00 E+\infty 0$ & $0.00 \mathrm{E} \div \infty 0$ & $0.00 E+\infty$ & $0.00 E+\infty$ & $0.00 \mathrm{E}+\infty 0$ & $0.00 E+\infty$ \\
\hline
\end{tabular}

\begin{tabular}{|c|c|c|c|c|c|c|c|}
\hline \multirow{2}{*}{$\begin{array}{c}\text { Wind } \\
\text { Spced } \\
\text { Category }\end{array}$} & \multicolumn{7}{|c|}{2 hr Sector-Are Chi/Q } \\
\hline & A & B & C & $\mathrm{D}$ & $E$ & $F$ & $G$ \\
\hline 1 & $4.18 \mathrm{E}-07$ & $3.92 \mathrm{E}-07$ & $3.45 \mathrm{E}-07$ & $321 \mathrm{E}-07$ & $4.53 \mathrm{E}-07$ & $0.00 \mathrm{E}+00$ & $0.00 \mathrm{E}+\infty 0$ \\
\hline 2 & $1.91 E-07$ & $1.83 E-07$ & $1.84 \mathrm{E}-07$ & $1.79 \mathrm{E}-07$ & $2.49 E-07$ & 433E-07 & $9.93 \mathrm{E}-07$ \\
\hline 3 & $1.19 \mathrm{E}-07$ & $1.19 \mathrm{E}-07$ & $1.14 E-07$ & $1.15 \mathrm{E}-07$ & $1.69 \mathrm{E}-07$ & $2.90 \mathrm{E}-07$ & 4.95E-07 \\
\hline 4 & $8.77 \mathrm{E}-08$ & $8.14 E-08$ & 837E-08 & $8.19 E-08$ & $123 E-07$ & $235 E-07$ & $3.99 E-07$ \\
\hline 5 & $0.00 \mathrm{E}+\infty 0$ & $0.00 \mathrm{E}+\infty 0$ & $0.00 \mathrm{E}+00$ & $6.22 \mathrm{E}-08$ & $9.75 E-08$ & $0.00 \mathrm{E}+00$ & $0.00 E+\infty$ \\
\hline 6 & $0.00 E+\infty$ & $0.00 \mathrm{E}+\infty$ & $0.00 \mathrm{E}+\infty 0$ & $0.00 E+\infty$ & $0.00 E+\infty 0$ & $0.00 E+\infty$ & $0.00 \mathrm{E}+\infty 0$ \\
\hline
\end{tabular}

\begin{tabular}{c|ccccccc}
$\begin{array}{c}\text { Wind } \\
\text { Speed } \\
\text { Category }\end{array}$ & A & B & C & Annual Average Sector-Arc Chi/Q \\
Stability Category \\
\hline 1 & $4.75 E-07$ & $4.61 \mathrm{E}-07$ & $4.12 \mathrm{E}-07$ & $4.30 \mathrm{E}-07$ & $7.46 \mathrm{E}-07$ & $0.00 \mathrm{E}+00$ & $0.00 \mathrm{E}+00$ \\
2 & $2.17 \mathrm{E}-07$ & $2.15 \mathrm{E}-07$ & $2.20 \mathrm{E}-07$ & $2.39 \mathrm{E}-07$ & $4.10 \mathrm{E}-07$ & $8.52 \mathrm{E}-07$ & $1.95 \mathrm{E}-06$ \\
3 & $1.36 \mathrm{E}-07$ & $1.40 \mathrm{E}-07$ & $1.36 \mathrm{E}-07$ & $1.54 \mathrm{E}-07$ & $2.78 \mathrm{E}-07$ & $5.70 \mathrm{E}-07$ & $9.73 \mathrm{E}-07$ \\
4 & $9.97 \mathrm{E}-08$ & $9.56 \mathrm{E}-08$ & $1.00 \mathrm{E}-07$ & $1.09 \mathrm{E}-07$ & $2.03 \mathrm{E}-07$ & $4.62 \mathrm{E}-07$ & $7.84 \mathrm{E}-07$ \\
5 & $0.00 \mathrm{E}+\infty$ & $0.00 \mathrm{E}+\infty$ & $0.00 \mathrm{E}+\infty$ & $8.31 \mathrm{E}-08$ & $1.61 \mathrm{E}-07$ & $0.00 \mathrm{E}+\infty$ & $0.00 \mathrm{E}+\infty 0$ \\
6 & $0.00 \mathrm{E}+\infty$ & $0.00 \mathrm{E}+\infty$ & $0.00 \mathrm{E}+\infty$ & $0.00 \mathrm{E}+\infty$ & $0.00 \mathrm{E}+\infty$ & $0.00 \mathrm{E}+\infty$ & $0.00 \mathrm{E}+\infty$
\end{tabular}

Annual Average $=1.317 \mathrm{E}-08 \quad$ (average $\mathrm{X} / \mathrm{Q}$ weighted by JFD). 
Determination of 99.5 Percentile Relative Concentration
Sector:
WNW 24135 (15 mi)
Stack / Vent
Distance: 24135 (15 mi)

\begin{tabular}{|l|l|l|}
\hline Ordered X/Q & \multicolumn{1}{|c|}{ Freq. } & Cum. Freq. \\
\hline $9.93 \mathrm{E}-7$ & 0.0028 & 0.0028 \\
\hline $4.95 \mathrm{E}-7$ & 0.0057 & 0.0085 \\
\hline $4.53 \mathrm{E}-7$ & 0.0227 & 0.0312 \\
\hline $4.33 \mathrm{E}-7$ & 0.0766 & 0.1078 \\
\hline $4.18 \mathrm{E}-7$ & 0.2326 & 0.3404 \\
\hline $3.99 \mathrm{E}-7$ & 0.0028 & 0.3432 \\
\hline $3.92 \mathrm{E}-7$ & 0.0567 & 0.3999 \\
\hline $3.45 \mathrm{E}-7$ & 0.0454 & 0.4453 \\
\hline $3.21 \mathrm{E}-7$ & 0.0340 & 0.4793 \\
\hline $2.90 \mathrm{E}-7$ & 0.1759 & 0.6552 \\
\hline & & \\
\hline & & \\
\hline & & \\
\hline
\end{tabular}

\begin{tabular}{|c|c|}
\hline $\begin{array}{c}\text { High C.F. } \\
\text { (a) } 0.6552\end{array}$ & $\begin{array}{c}\text { X/Q } \\
\text { (c) } 2.90 \mathrm{E}-7\end{array}$ \\
\hline $\begin{array}{c}\text { Low C.F. } \\
\text { (b ad Cat.) } \\
\text { (b) } 0.4793\end{array}$ & (d) $3.21 \mathrm{E}-7$ \\
\hline
\end{tabular}

$99.5 \% \times / Q 3.17 \mathrm{E}-7$

- Interpolation Formula:

$c+((c-d) \cdot(0.5-a) /(a-b))$

Interpolation Factor: (0.5-a)/(a-b)

Interpolation Factor: -0.8823

1st Stab./Speed Cat::

2nd Stab./Speed Cat: 


\section{RELATIVE AIR CONCENTRATION}

SECTOR: WNW RELHGT $=50 \quad$ Terrain $(\mathrm{ft})=144 \quad$ XDIS $=40225$

\begin{tabular}{c|ccccccc}
$\begin{array}{c}\text { Wind } \\
\text { Speed } \\
\text { Category }\end{array}$ & A & B & C & $\begin{array}{c}\text { Soint Freqency Distribution } \\
\text { Stability Category }\end{array}$ \\
\hline 1 & 0.2326 & 0.0567 & 0.0454 & 0.0340 & 0.0227 & 0.0000 & 0.0000 \\
2 & 0.5872 & 0.2780 & 0.3801 & 0.6127 & 0.4227 & 0.0766 & 0.0028 \\
3 & 0.1418 & 0.1362 & 0.2411 & 0.5220 & 0.5673 & 0.1759 & 0.0057 \\
4 & 0.0028 & 0.0113 & 0.0312 & 0.1475 & 0.0567 & 0.0369 & 0.0028 \\
5 & 0.0000 & 0.0000 & 0.0000 & 0.0142 & 0.0057 & 0.0000 & 0.0000 \\
6 & 0.0000 & 0.0000 & 0.0000 & 0.0000 & 0.0000 & 0.0000 & 0.0000
\end{tabular}

\begin{tabular}{c|ccccccc}
$\begin{array}{c}\text { Wind } \\
\text { Speed } \\
\text { Category }\end{array}$ & A & B & C & $\begin{array}{c}2 \text { hr Centerline Chi/Q } \\
\text { Stability Category } \\
\text { D }\end{array}$ & E & F & G \\
\hline 1 & $3.00 \mathrm{E}-07$ & $3.74 \mathrm{E}-07$ & $4.34 \mathrm{E}-07$ & $5.74 \mathrm{E}-07$ & $9.32 \mathrm{E}-07$ & $0.00 \mathrm{E}+\infty$ & $0.00 \mathrm{E}+\infty$ \\
2 & $1.37 \mathrm{E}-07$ & $1.75 \mathrm{E}-07$ & $2.32 \mathrm{E}-07$ & $3.19 \mathrm{E}-07$ & $5.13 \mathrm{E}-07$ & $1.35 \mathrm{E}-06$ & $4.67 \mathrm{E}-06$ \\
3 & $8.55 \mathrm{E}-08$ & $1.13 \mathrm{E}-07$ & $1.43 \mathrm{E}-07$ & $2.05 \mathrm{E}-07$ & $3.47 \mathrm{E}-07$ & $9.01 \mathrm{E}-07$ & $232 \mathrm{E}-\infty 6$ \\
4 & $6.29 \mathrm{E}-08$ & $7.77 \mathrm{E}-08$ & $1.05 \mathrm{E}-07$ & $1.46 \mathrm{E}-07$ & $2.54 \mathrm{E}-07$ & $7.31 \mathrm{E}-07$ & $1.87 \mathrm{E}-06$ \\
5 & $0.00 \mathrm{E}+\infty$ & $0.00 \mathrm{E}+\infty$ & $0.00 \mathrm{E}+\infty$ & $1.11 \mathrm{E}-07$ & $2.01 \mathrm{E}-07$ & $0.00 \mathrm{E}+\infty$ & $0.00 \mathrm{E}+\infty$ \\
6 & $0.00 \mathrm{E}+\infty$ & $0.00 \mathrm{E}+\infty$ & $0.00 \mathrm{E}+\infty$ & $0.00 \mathrm{E}+\infty$ & $0.00 \mathrm{E}+\infty$ & $0.00 \mathrm{E}+\infty$ & $0.00 \mathrm{E}+\infty$
\end{tabular}

\begin{tabular}{c|ccccccc}
$\begin{array}{c}\text { Wind } \\
\text { Speed } \\
\text { Category }\end{array}$ & A & B & C & $\begin{array}{c}\text { 2 br Sector-Arc Chi/Q } \\
\text { Stability Category }\end{array}$ \\
\hline 1 & $2.51 \mathrm{E}-07$ & $2.35 \mathrm{E}-07$ & $2.07 \mathrm{E}-07$ & $1.93 \mathrm{E}-07$ & $2.23 \mathrm{E}-07$ & $0.00 \mathrm{E}+\infty$ & $0.00 \mathrm{E}+\infty$ \\
2 & $1.15 \mathrm{E}-07$ & $1.10 \mathrm{E}-07$ & $1.11 \mathrm{E}-07$ & $1.07 \mathrm{E}-07$ & $1.22 \mathrm{E}-07$ & $2.22 \mathrm{E}-07$ & $5.31 \mathrm{E}-07$ \\
3 & $7.15 \mathrm{E}-08$ & $7.13 \mathrm{E}-08$ & $6.83 \mathrm{E}-08$ & $6.90 \mathrm{E}-08$ & $8.30 \mathrm{E}-08$ & $1.49 \mathrm{E}-07$ & $2.65 \mathrm{E}-07$ \\
4 & $5.26 \mathrm{E}-08$ & $4.88 \mathrm{E}-08$ & $5.02 \mathrm{E}-08$ & $4.92 \mathrm{E}-08$ & $6.08 \mathrm{E}-08$ & $1.21 \mathrm{E}-07$ & $213 \mathrm{E}-07$ \\
5 & $0.00 \mathrm{E}+\infty$ & $0.00 \mathrm{E}+\infty$ & $0.00 \mathrm{E}+\infty$ & $3.73 \mathrm{E}-08$ & $4.80 \mathrm{E}-08$ & $0.00 \mathrm{E}+\infty$ & $0.00 \mathrm{E}+\infty$ \\
6 & $0.00 \mathrm{E}+\infty$ & $0.00 \mathrm{E}+\infty$ & $0.00 \mathrm{E}+\infty$ & $0.00 \mathrm{E}+\infty$ & $0.00 \mathrm{E}+\infty$ & $0.00 \mathrm{E}+\infty$ & $0.00 \mathrm{E}+\infty$
\end{tabular}

\begin{tabular}{c|ccccccc}
$\begin{array}{c}\text { Wind } \\
\text { Speed } \\
\text { Category }\end{array}$ & A & B & C & D & E & F & G \\
\hline 1 & $285 \mathrm{E}-07$ & $2.76 \mathrm{E}-07$ & $2.47 \mathrm{E}-07$ & $258 \mathrm{E}-07$ & $3.67 \mathrm{E}-07$ & $0.00 \mathrm{E}+00$ & $0.00 \mathrm{E}+\infty$ \\
2 & $1.30 \mathrm{E}-07$ & $1.29 \mathrm{E}-07$ & $1.32 \mathrm{E}-07$ & $1.43 \mathrm{E}-07$ & $2.02 \mathrm{E}-07$ & $4.37 \mathrm{E}-07$ & $1.04 \mathrm{E}-06$ \\
3 & $8.13 \mathrm{E}-08$ & $8.38 \mathrm{E}-08$ & $8.15 \mathrm{E}-08$ & $9.22 \mathrm{E}-08$ & $1.37 \mathrm{E}-07$ & $2.92 \mathrm{E}-07$ & $5.21 \mathrm{E}-07$ \\
4 & $5.98 \mathrm{E}-08$ & $5.74 \mathrm{E}-08$ & $6.00 \mathrm{E}-08$ & $6.57 \mathrm{E}-08$ & $1.00 \mathrm{E}-07$ & $2.37 \mathrm{E}-07$ & $4.20 \mathrm{E}-07$ \\
5 & $0.00 \mathrm{E}+\infty$ & $0.00 \mathrm{E}+00$ & $0.00 \mathrm{E}+\infty$ & $4.98 \mathrm{E}-08$ & $7.90 \mathrm{E}-08$ & $0.00 \mathrm{E}+\infty$ & $0.00 \mathrm{E}+\infty$ \\
6 & $0.00 \mathrm{E}+\infty$ & $0.00 \mathrm{E}+\infty$ & $0.00 \mathrm{E}+\infty$ & $0.00 \mathrm{E}+\infty$ & $0.00 \mathrm{E}+\infty$ & $0.00 \mathrm{E}+\infty$ & $0.00 \mathrm{E}+\infty$
\end{tabular}

Annual Average $=7.343 E-09$ (average X/Q weighted by JFD). 
Determination of 99.5 Percentile Relative Concentration

Sector: WNW

Stack / Vent

Distance: $40225(25 \mathrm{mi})$

\begin{tabular}{|l|l|l|}
\hline Ordered X/Q & \multicolumn{1}{|c|}{ Freq. } & Cum. Freq. \\
\hline $5.31 \mathrm{E}-7$ & 0.0028 & 0.0028 \\
\hline $2.65 \mathrm{E}-7$ & 0.0057 & 0.0085 \\
\hline $2.51 \mathrm{E}-7$ & 0.2326 & 0.2411 \\
\hline $2.35 \mathrm{E}-7$ & 0.0567 & 0.2978 \\
\hline $2.23 \mathrm{E}-7$ & 0.0227 & 0.3205 \\
\hline $2.22 \mathrm{E}-7$ & 0.0766 & 0.3971 \\
\hline $2.13 \mathrm{E}-7$ & 0.0028 & 0.3999 \\
\hline $2.07 \mathrm{E}-7$ & 0.0454 & 0.4453 \\
\hline $1.93 \mathrm{E}-7$ & 0.0340 & 0.4793 \\
\hline $1.49 \mathrm{E}-7$ & 0.1759 & 0.6552 \\
\hline & & \\
\hline & & \\
\hline
\end{tabular}

\begin{tabular}{|c|c|}
\hline $\begin{array}{l}\text { High C.F. } \\
\text { (a) } 0.6552\end{array}$ & $X / Q$ \\
\hline $\begin{array}{l}\text { Low C.F. } \\
\text { (b) } 0.4793\end{array}$ & $\begin{array}{c}X / Q \\
\text { (d) } 1.93 \mathrm{E}-7\end{array}$ \\
\hline
\end{tabular}

$99.5 \% \mathrm{X} / \mathrm{Q} 1.88 \mathrm{E}-7$

- Interpolation Formula:

$c+((c-d) \cdot(0.5-a) /(a-b))$

Interpolation Factor: (0.5-a)/(a-b)

Interpolation Factor: -0.8823

1st Stab./Speed Cat:

$4-1$

2nd Stab./Speed Cat.:

$6-3$ 


\section{RELATTVE AIR CONCENTRATION}

$$
\text { SECTOR: WNW RELHGT }=50 \quad \text { Terrain }(\mathrm{ft})=284 \quad \text { XDIS }=56315
$$

\begin{tabular}{c|ccccccc}
$\begin{array}{c}\text { Wind } \\
\text { Speed } \\
\text { Category }\end{array}$ & A & B & C & $\begin{array}{c}\text { Soint Frequency Distribution } \\
\text { Stability Category }\end{array}$ \\
\hline 1 & 0.2326 & 0.0567 & 0.0454 & 0.0340 & 0.0227 & 0.0000 & 0.0000 \\
2 & 0.5872 & 0.2780 & 0.3801 & 0.6127 & 0.4227 & 0.0766 & 0.0028 \\
3 & 0.1418 & 0.1362 & 0.2411 & 0.5220 & 0.5673 & 0.1759 & 0.0057 \\
4 & 0.0028 & 0.0113 & 0.0312 & 0.1475 & 0.0567 & 0.0369 & 0.0028 \\
5 & 0.0000 & 0.0000 & 0.0000 & 0.0142 & 0.0057 & 0.0000 & 0.0000 \\
6 & 0.0000 & 0.0000 & 0.0000 & 0.0000 & 0.0000 & 0.0000 & 0.0000
\end{tabular}

\begin{tabular}{|c|c|c|c|c|c|c|c|}
\hline \multirow{2}{*}{$\begin{array}{l}\text { Wind } \\
\text { Speed } \\
\text { Category }\end{array}$} & \multicolumn{7}{|c|}{$\begin{array}{c}2 \text { hr Centerline Chi/Q } \\
\text { Stability Category }\end{array}$} \\
\hline & A & B & C & D & $E$ & F & $G$ \\
\hline 1 & $2.22 \mathrm{E}-07$ & $2.76 E-07$ & $3.20 \mathrm{E}-07$ & $424 \mathrm{E}-07$ & $6.07 \mathrm{E}-07$ & $0.00 E+\infty$ & $0.00 E+00$ \\
\hline 2 & $1.01 \mathrm{E}-07$ & $1.29 E-07$ & $1.71 E-07$ & $2.35 \mathrm{E}-07$ & $334 \mathrm{E}-07$ & $9.04 E-07$ & $3.25 \mathrm{E}-06$ \\
\hline 3 & $632 \mathrm{E}-08$ & 838E-08 & $1.06 \mathrm{E}-07$ & $152 \mathrm{E}-07$ & $2.26 \mathrm{E}-07$ & $6.04 E-07$ & $1.62 E-06$ \\
\hline 4 & $4.65 \mathrm{E}-08$ & $5.74 E-08$ & $7.77 \mathrm{E}-08$ & $1.08 E-07$ & $1.66 \mathrm{E}-07$ & $4.90 \mathrm{E}-07$ & $1.30 E-06$ \\
\hline 5 & $0.00 E+\infty 0$ & $0.00 \mathrm{E}+\infty 00$ & $0.00 E \div \infty$ & $8.20 \mathrm{E}-08$ & $131 \mathrm{E}-07$ & $0.00 E+\infty$ & $0.00 E+\infty$ \\
\hline 6 & $0.00 \mathrm{E}+\infty$ & $0.00 E+00$ & $0.00 \mathrm{E}+\infty$ & $0.00 E+\infty$ & $0.00 E+\infty$ & $0.00 E+\infty$ & $0.00 E \div \infty$ \\
\hline
\end{tabular}

\begin{tabular}{c|ccccccc}
$\begin{array}{c}\text { Wind } \\
\text { Speed } \\
\text { Category }\end{array}$ & A & B & C & $\begin{array}{c}\text { 2 br Sector-Arc Chi/Q } \\
\text { Stability Category } \\
\text { D }\end{array}$ & E & F & $G$ \\
\hline 1 & $1.79 \mathrm{E}-07$ & $1.68 \mathrm{E}-07$ & $1.48 \mathrm{E}-07$ & $1.38 \mathrm{E}-07$ & $1.40 \mathrm{E}-07$ & $0.00 \mathrm{E}+\infty$ & $0.00 \mathrm{E}+\infty$ \\
2 & $8.19 \mathrm{E}-08$ & $7.86 \mathrm{E}-08$ & $7.91 \mathrm{E}-08$ & $7.66 \mathrm{E}-08$ & $7.72 \mathrm{E}-08$ & $1.44 \mathrm{E}-07$ & $3.58 \mathrm{E}-07$ \\
3 & $5.11 \mathrm{E}-08$ & $5.10 \mathrm{E}-08$ & $4.88 \mathrm{E}-08$ & $4.93 \mathrm{E}-08$ & $5.23 \mathrm{E}-08$ & $9.65 \mathrm{E}-08$ & $1.78 \mathrm{E}-07$ \\
4 & $3.76 \mathrm{E}-08$ & $3.49 \mathrm{E}-08$ & $359 \mathrm{E}-08$ & $3.51 \mathrm{E}-08$ & $3.83 \mathrm{E}-08$ & $7.83 \mathrm{E}-08$ & $1.44 \mathrm{E}-07$ \\
5 & $0.00 \mathrm{E}+\infty$ & $0.00 \mathrm{E}+00$ & $0.00 \mathrm{E}+\infty$ & $2.67 \mathrm{E}-08$ & $3.02 \mathrm{E}-08$ & $0.00 \mathrm{E}+\infty$ & $0.00 \mathrm{E}+\infty$ \\
6 & $0.00 \mathrm{E}+\infty$ & $0.00 \mathrm{E}+\infty$ & $0.00 \mathrm{E}+\infty$ & $0.00 \mathrm{E}+\infty$ & $0.00 \mathrm{E}+\infty$ & $0.00 \mathrm{E}+\infty$ & $0.00 \mathrm{E}+\infty$
\end{tabular}

\begin{tabular}{c|ccccccc}
$\begin{array}{c}\text { Wind } \\
\text { Speed } \\
\text { Category }\end{array}$ & A & B & C & Annual Average Sector-Arc Chi/Q \\
Stability Category \\
\hline 1 & $2.04 \mathrm{E}-07$ & $1.98 \mathrm{E}-07$ & $1.77 \mathrm{E}-07$ & $1.84 \mathrm{E}-07$ & $2.31 \mathrm{E}-07$ & $0.00 \mathrm{E}+\infty$ & $0.00 \mathrm{E}+\infty$ \\
2 & $9.32 \mathrm{E}-08$ & $9.24 \mathrm{E}-08$ & $9.44 \mathrm{E}-08$ & $1.02 \mathrm{E}-07$ & $1.27 \mathrm{E}-07$ & $2.84 \mathrm{E}-07$ & $7.04 \mathrm{E}-07$ \\
3 & $5.81 \mathrm{E}-08$ & $5.99 \mathrm{E}-08$ & $5.83 \mathrm{E}-08$ & $6.59 \mathrm{E}-08$ & $8.62 \mathrm{E}-08$ & $1.90 \mathrm{E}-07$ & $3.50 \mathrm{E}-07$ \\
4 & $4.28 \mathrm{E}-08$ & $4.10 \mathrm{E}-08$ & $4.29 \mathrm{E}-08$ & $4.70 \mathrm{E}-08$ & $6.31 \mathrm{E}-08$ & $1.54 \mathrm{E}-07$ & $2.83 \mathrm{E}-07$ \\
5 & $0.00 \mathrm{E}+\infty$ & $0.00 \mathrm{E}+\infty$ & $0.00 \mathrm{E}+00$ & $3.56 \mathrm{E}-08$ & $4.98 \mathrm{E}-08$ & $0.00 \mathrm{E}+\infty$ & $0.00 \mathrm{E}+\infty$ \\
6 & $0.00 \mathrm{E}+\infty$ & $0.00 \mathrm{E}+\infty$ & $0.00 \mathrm{E}+00$ & $0.00 \mathrm{E}+00$ & $0.00 \mathrm{E}+\infty$ & $0.00 \mathrm{E}+\infty$ & $0.00 \mathrm{E}+\infty$
\end{tabular}

Annual Average $=5.034 \mathrm{E}-09$ (average $X / Q$ weighted by JFD). 


\section{Determination of 99.5 Percentile Relative Concentration}

$\begin{aligned} \text { Sector: } & \text { WNw } \\ \text { Distance: } & 56315(35 \mathrm{mi})\end{aligned}$

\begin{tabular}{|l|l|l|}
\hline Ordered X/Q & \multicolumn{1}{|c|}{ Freq. } & Cum. Freq. \\
\hline $3.58 \mathrm{E}-7$ & 0.0028 & 0.0028 \\
\hline $1.79 \mathrm{E}-7$ & 0.2326 & 0.2354 \\
\hline $1.78 \mathrm{E}-7$ & 0.0057 & 0.2411 \\
\hline $1.68 \mathrm{E}-7$ & 0.0567 & 0.2978 \\
\hline $1.48 \mathrm{E}-7$ & 0.0454 & 0.3432 \\
\hline $1.44 \mathrm{E}-7$ & 0.0766 & 0.4198 \\
\hline $1.44 \mathrm{E}-7$ & 0.0028 & 0.4226 \\
\hline $1.40 \mathrm{E}-7$ & 0.0227 & 0.4453 \\
\hline $1.38 \mathrm{E}-7$ & 0.0340 & 0.4793 \\
\hline $9.65 \mathrm{E}-8$ & 0.1759 & 0.6552 \\
\hline & & \\
\hline & & \\
\hline
\end{tabular}

Stack / Vent

\begin{tabular}{|c|c|}
\hline $\begin{array}{c}\text { High C.F. } \\
\text { (a) } 0.6552\end{array}$ & X/Q \\
(c) $9.65 \mathrm{E}-8$ \\
\hline Low C.F. & X/Q \\
(b) 0.4793 & (d) $1.38 \mathrm{nd}-7$ \\
\hline
\end{tabular}

$99.5 \% \times / \mathrm{Q} 1.33 \mathrm{E}-7$

- Interpolation Formula:

$c+((c-d)=(0.5-a) /(a-b))$

Interpolation Factor: $(0.5-\mathrm{a}) /(\mathrm{a}-\mathrm{b})$

Interpolation Factor: -0.8823

1st Stab./Speed Cat:

$4-1$

2nd Stab./Speed Cat:

$6-3$ 
RELATTVE AIR CONCENTRATION

SECTOR: WNW RELHGT $=50 \quad$ Terrain $(\mathrm{ft})=284 \quad$ XDIS $=72405$

\begin{tabular}{c|ccccccc}
$\begin{array}{c}\text { Wind } \\
\text { Speed } \\
\text { Category }\end{array}$ & A & B & C & Joint Freqency Distribution \\
Stability Category \\
\hline 1 & 0.2326 & 0.0567 & 0.0454 & 0.0340 & 0.0227 & 0.0000 & 0.0000 \\
2 & 0.5872 & 0.2780 & 0.3801 & 0.6127 & 0.4227 & 0.0766 & 0.0028 \\
3 & 0.1418 & 0.1362 & 0.2411 & 0.5220 & 0.5673 & 0.1759 & 0.0057 \\
4 & 0.0028 & 0.0113 & 0.0312 & 0.1475 & 0.0567 & 0.0369 & 0.0028 \\
5 & 0.0000 & 0.0000 & 0.0000 & 0.0142 & 0.0057 & 0.0000 & 0.0000 \\
6 & 0.0000 & 0.0000 & 0.0000 & 0.0000 & 0.0000 & 0.0000 & 0.0000
\end{tabular}

\begin{tabular}{|c|c|c|c|c|c|c|c|}
\hline \multirow{2}{*}{$\begin{array}{c}\text { Wind } \\
\text { Speed } \\
\text { Category }\end{array}$} & \multicolumn{7}{|c|}{$\begin{array}{c}2 \text { br Centerline Chi/Q } \\
\text { Stability Category }\end{array}$} \\
\hline & A & B & $\mathrm{C}$ & D & E & $F$ & $G$ \\
\hline 1 & $1.77 \mathrm{E}-07$ & $2.20 \mathrm{E}-07$ & $255 \mathrm{E}-07$ & $338 E-07$ & $4.69 \mathrm{E}-07$ & $0.00 E+00$ & $0.00 E+00$ \\
\hline 2 & 8.07E-08 & $1.03 E-07$ & $1.36 \mathrm{E}-07$ & $1.88 \mathrm{E}-07$ & $258 \mathrm{E}-07$ & $6.71 E-07$ & $2.46 E-06$ \\
\hline 3 & $5.03 E-08$ & $6.68 \mathrm{E}-08$ & $8.42 \mathrm{E}-0.08$ & $121 E-07$ & $1.75 \mathrm{E}-07$ & 4.49E-07 & $123 E-06$ \\
\hline 4 & 3.70E-08 & 45TE-08 & 6.19E-08 & 8.61E-08 & $128 \mathrm{E}-07$ & $3.64 E-07$ & $9.88 E-07$ \\
\hline 5 & $0.00 E+\infty$ & $0.00 \mathrm{E}+\infty$ & $0.00 E+\infty$ & $6.53 E-08$ & $1.01 E-07$ & $0.00 \mathrm{E}+\infty 0$ & $0.00 E+\infty$ \\
\hline 6 & $0.00 E+\infty$ & $0.00 \mathrm{E}+\infty$ & $0.00 E+\infty$ & $0.00 E+\infty$ & $0.00 E+\infty$ & $0.00 \mathrm{E}+\infty 0$ & $0.00 E+\infty 0$ \\
\hline
\end{tabular}

\begin{tabular}{|c|c|c|c|c|c|c|c|}
\hline \multirow{2}{*}{$\begin{array}{l}\text { Wind } \\
\text { Speed } \\
\text { Category }\end{array}$} & \multicolumn{7}{|c|}{$\begin{array}{c}2 \mathrm{hr} \text { Sector-Arc Chi/Q } \\
\text { Stability Category }\end{array}$} \\
\hline & A & B & C & D & $E$ & $F$ & $G$ \\
\hline 1 & $139 \mathrm{E}-07$ & 131E-O7 & $1.15 \mathrm{E}-07$ & 1.0TE-07 & $1.06 \mathrm{E}-07$ & $0.00 E+\infty$ & $0.00 E+\infty 0$ \\
\hline 2 & 6.3TE-08 & $6.12 E-08$ & $6.15 E-08$ & $5.96 \mathrm{E}-088$ & $5.82 \mathrm{E}-08$ & $1.05 E-07$ & $2.65 \mathrm{E}-07$ \\
\hline 3 & $3.97 \mathrm{E}-08$ & $3.96 \mathrm{E}-08$ & $3.80 \mathrm{E}-08$ & $3.84 E-08$ & $3.95 \mathrm{E}-08$ & $6.99 E-08$ & $1.32 \mathrm{E}-07$ \\
\hline 4 & $2.93 E-08$ & $272 \mathrm{E}-08$ & $279 \mathrm{E}-08$ & $273 E-08$ & $2.89 E-08$ & $5.67 \mathrm{E}-08$ & $1.06 \mathrm{E}-07$ \\
\hline 5 & $0.00 E+00$ & $0.00 E+\infty 0$ & $0.00 \mathrm{E}+\infty$ & 207E-08 & $2.28 \mathrm{E}-08$ & $0.00 \mathrm{E}+\infty 00$ & $0.00 E+\infty$ \\
\hline 6 & $0.00 E+\infty 0$ & $0.00 \mathrm{E}+\infty 0$ & $0.00 E+\infty$ & $0.00 E+\infty$ & $0.00 \mathrm{E}+\infty$ & $0.00 \mathrm{E}+\infty 00$ & $0.00 E+\infty$ \\
\hline
\end{tabular}

\begin{tabular}{c|ccccccc}
$\begin{array}{c}\text { Wind } \\
\text { Speed } \\
\text { Category }\end{array}$ & A & B & C & Annual Average Sector-Arc Chi/Q \\
Stability Category & D & E & F & G \\
\hline 1 & $159 \mathrm{E}-07$ & $1.54 \mathrm{E}-07$ & $1.37 \mathrm{E}-07$ & $1.43 \mathrm{E}-07$ & $1.74 \mathrm{E}-07$ & $0.00 \mathrm{E}+00$ & $0.00 \mathrm{E}+\infty$ \\
2 & $7.25 \mathrm{E}-08$ & $7.18 \mathrm{E}-08$ & $734 \mathrm{E}-08$ & $7.96 \mathrm{E}-08$ & $9.59 \mathrm{E}-08$ & $2.06 \mathrm{E}-07$ & $5.20 \mathrm{E}-07$ \\
3 & $4.52 \mathrm{E}-08$ & $4.66 \mathrm{E}-08$ & $4.53 \mathrm{E}-08$ & $5.13 \mathrm{E}-08$ & $6.50 \mathrm{E}-08$ & $1.37 \mathrm{E}-07$ & $2.59 \mathrm{E}-07$ \\
4 & $3.33 \mathrm{E}-08$ & $3.19 \mathrm{E}-08$ & $3.33 \mathrm{E}-08$ & $3.65 \mathrm{E}-08$ & $4.76 \mathrm{E}-08$ & $1.11 \mathrm{E}-07$ & $2.09 \mathrm{E}-07$ \\
5 & $0.00 \mathrm{E}+\infty$ & $0.00 \mathrm{E}+\infty$ & $0.00 \mathrm{E}+\infty$ & $2.77 \mathrm{E}-08$ & $3.76 \mathrm{E}-08$ & $0.00 \mathrm{E}+\infty$ & $0.00 \mathrm{E}+\infty$ \\
6 & $0.00 \mathrm{E}+\infty$ & $0.00 \mathrm{E}+\infty$ & $0.00 \mathrm{E}+\infty$ & $0.00 \mathrm{E}+\infty$ & $0.00 \mathrm{E}+\infty$ & $0.00 \mathrm{E}+\infty$ & $0.00 \mathrm{E}+\infty$
\end{tabular}

Annual Average $=3.855 \mathrm{E}-09$ (average $X / Q$ weighted by JFD). 


\title{
Determination of 99.5 Percentile Relative Concentration
}

\author{
Sector: \\ Distance: $\overline{72405(45 \mathrm{Yi})}$
}

Stack / Vent

\begin{tabular}{|l|l|l|}
\hline Ordered X/Q & \multicolumn{1}{|c|}{ Freq. } & Cum. Freq. \\
\hline $2.65 \mathrm{E}-7$ & 0.0028 & 0.0028 \\
\hline $1.39 \mathrm{E}-7$ & 0.2326 & 0.2354 \\
\hline $1.32 \mathrm{E}-7$ & 0.0057 & 0.2411 \\
\hline $1.31 \mathrm{E}-7$ & 0.0567 & 0.2978 \\
\hline $1.15 \mathrm{E}-7$ & 0.0454 & 0.3432 \\
\hline $1.07 \mathrm{E}-7$ & 0.0340 & 0.3772 \\
\hline $1.06 \mathrm{E}-7$ & 0.0227 & 0.3999 \\
\hline $1.06 \mathrm{E}-7$ & 0.0028 & 0.4027 \\
\hline $1.05 \mathrm{E}-7$ & 0.0766 & 0.4793 \\
\hline $6.99 \mathrm{E}-8$ & 0.1759 & 0.6552 \\
\hline & & \\
\hline & & \\
\hline
\end{tabular}

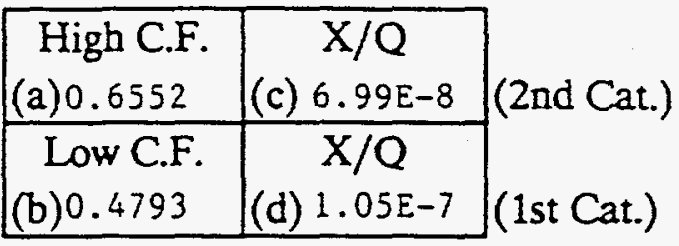

$99.5 \% \times / Q \quad 1.01 E-7$

- Interpolation Formula:

$c+((c-d)=(0.5-a) /(a-b))$

Interpolation Factor: (0.5-a)/(a-b)

Interpolation Factor: -0.8823

1st Stab./Speed Cat.:

$6-2$

2nd Stab./Speed Cat.: $6-3$ 
Verification of the PRIMUSL routine.

\begin{tabular}{|c|c|c|}
\hline \multicolumn{3}{|c|}{ Ingrowth Factors* } \\
\hline Nuclide & $\begin{array}{l}\text { Activity } \\
\text { at } 2 \text { hours }\end{array}$ & $\begin{array}{l}\text { Activity } \\
\text { at boundar }\end{array}$ \\
\hline Rn-222 & $9.85 \mathrm{E}-01$ & 9.95E-01 \\
\hline Po-218 & $9.85 E-01$ & $9.95 E-01$ \\
\hline $\mathrm{Pb}-214$ & $9.40 \mathrm{E}-01$ & $6.37 \mathrm{E}-01$ \\
\hline $\mathrm{Bi}-214$ & $8.52 \mathrm{E}-01$ & 3.31E-01 \\
\hline Po-214 & $8.51 \mathrm{E}-01$ & 3.31E-01 \\
\hline $\mathrm{Pb}-210$ & $3.25 E-06$ & $3.21 E-07$ \\
\hline $\mathrm{Bi}-210$ & $1.21 \mathrm{E}-08$ & $3.52 \mathrm{E}-10$ \\
\hline Po-210 & $1.18 \mathrm{E}-12$ & $1.08 \mathrm{E}-14$ \\
\hline
\end{tabular}

\begin{tabular}{|ccc|}
\hline \multicolumn{3}{|c|}{ Dose Factors } \\
\hline & Inhalation \\
Effective & Shine \\
\hline Nuclide & D.F. & D.F. \\
Rn-222 & 0 & 1.95 \\
Po-218 & 0 & 0 \\
$\mathrm{~Pb}-214$ & 0.0067 & 1250 \\
$\mathrm{Bi}-214$ & 0.0063 & 8110 \\
$\mathrm{Po}-214$ & 0 & 0.434 \\
$\mathrm{~Pb}-210$ & 13 & 6.7 \\
$\mathrm{Bi}-210$ & 0.19 & 0 \\
$\mathrm{Po}-210$ & 8.1 & 0.0444 \\
\hline
\end{tabular}

Maximum individual at the NNW boundary (11870 meters). Approximate Transit Time: $4.49 \mathrm{~m} / \mathrm{s}$

Hand-Calculation $* *$

Inhalation Shine

CEDE Dose

\begin{tabular}{ccc} 
Nuclide & (mrem) & (mrem) \\
\hline Rn-222 & $0.00 \mathrm{E}+00$ & 1.93E 07. \\
$\mathrm{Po}-218$ & $0.00 \mathrm{E}+00$ & $0.00 \mathrm{E}+00$ \\
$\mathrm{~Pb}-214$ & $7.32 \mathrm{E}-03$ & $7.93 \mathrm{E}-05$ \\
$\mathrm{Bi}-214$ & $3.58 \mathrm{E}-03$ & $2.67 \mathrm{E}-04$ \\
$\mathrm{Po}-214$ & $0.00 \mathrm{E}+00$ & $1.43 \mathrm{E}-08$ \\
$\mathrm{~Pb}-210$ & $7.16 \mathrm{E}-06$ & $2.14 \mathrm{E}-13$ \\
$\mathrm{Bi}-210$ & $1.15 \mathrm{E}-10$ & $0.00 \mathrm{E}+00$ \\
$\mathrm{Po}-210$ & $1.51 \mathrm{E}-13$ & $4.79 \mathrm{E}-23$
\end{tabular}

AXAIR89Q Calculation

Inhalation Shine CEDE Dose

\begin{tabular}{ccc} 
Nuclide & (mrem) & (mrem) \\
\hline Rn-222 & $0.00 \mathrm{E}+00$ & $1.93 \mathrm{E}-07$ \\
Po-218 & $0.00 \mathrm{E}+00$ & $0.00 \mathrm{E}+00$ \\
$\mathrm{~Pb}-214$ & $7.32 \mathrm{E}-03$ & $7.64 \mathrm{E}-05$ \\
$\mathrm{Bi}-214$ & $3.30 \mathrm{E}-03$ & $1.98 \mathrm{E}-04$ \\
$\mathrm{Po}-214$ & $0.00 \mathrm{E}+00$ & $1.15 \mathrm{E}-08$ \\
$\mathrm{~Pb}-210$ & $6.05 \mathrm{E}-06$ & $3.34 \mathrm{E}-13$ \\
$\mathrm{Bi}-210$ & $9.12 \mathrm{E}-11$ & $0.00 \mathrm{E}+00$ \\
$\mathrm{Po}-210$ & $1.15 \mathrm{E}-13$ & $3.33 \mathrm{E}-23$
\end{tabular}

* Ingrowth factors from RADDECAY program by W.L. Marter.

-Formula: AXAIR89Q Dose x Ratio of Ingrowth Factors x Ratio of Dose Factors 
APPENDIX C. 


\section{SEMI-INFINITE PLUME GAMMA-SHINE DOSE}

\begin{tabular}{|c|c|c|c|c|c|c|c|}
\hline SECTOR: & NNW & RELHGT $=$ & & $\operatorname{Terrain}(\mathrm{ft})=$ & 154.3 & $\mathrm{XDIS}=$ & 11870 \\
\hline & & Nuclide $=$ & Be-7 & & & $\operatorname{ease}(\mathrm{Ci})=$ & $1.00 \mathrm{E}+\infty$ \\
\hline & Decay Const & at $(1 / \sec )=$ & $1.50 \mathrm{E}-07$ & Ext. & F (mrem cu & $a / u C i y r)=$ & $2.49 E+02$ \\
\hline Wind & & & $2 \mathrm{hr} C$ & terline Dose & mrem) & & \\
\hline Speed & & & & bility Categ & & & \\
\hline Category & A & B & C & D & $E$ & $\mathbf{F}$ & $\mathrm{G}$ \\
\hline 1 & $7.24 \mathrm{E}-06$ & $9.02 E-06$ & $1.31 \mathrm{E}-05$ & $2.22 \mathrm{E}-05$ & $8.42 \mathrm{E}-05$ & $3.58 \mathrm{E}-04$ & $0.00 \mathrm{E}+\infty 0$ \\
\hline 2 & $3.37 \mathrm{E}-06$ & $4.01 E-06$ & $5.43 E-06$ & $7.94 E-06$ & $1.98 \mathrm{E}-05$ & $4.79 \mathrm{E}-05$ & $0.00 \mathrm{E}+\infty 0$ \\
\hline 3 & $1.99 \mathrm{E}-06$ & $258 \mathrm{E}-06$ & $3-34 \mathrm{E}-06$ & $5.23 E-06$ & $131 E-05$ & $3.29 E-05$ & $7.52 E-05$ \\
\hline 4 & $1.39 E-06$ & $1.74 \mathrm{E}-06$ & $2.49 \mathrm{E}-06$ & $3.81 E-06$ & $9.64 \mathrm{E}-06$ & $2.47 \mathrm{E}-05$ & 5.71E-05 \\
\hline 5 & $1.06 \mathrm{E}-06$ & $0.00 E+\infty$ & $1.87 \mathrm{E}-06$ & $2.86 \mathrm{E}-06$ & $0.00 \mathrm{E}+\infty$ & $0.00 \mathrm{E}+\infty 0$ & $0.00 \mathrm{E}+\infty 0$ \\
\hline 6 & $0.00 \mathrm{E}+\infty 0$ & $0.00 E+\infty$ & $0.00 E+\infty$ & $0.00 E+\infty 0$ & $0.00 \mathrm{E}+\infty$ & $0.00 \mathrm{E}+\infty 0$ & $0.00 E+\infty$ \\
\hline
\end{tabular}

1st Stab./Speed Cat: $\quad 6-2$

2nd Stab./Speed Cat:: $6-3$

Formula: $b+\left[(b-a)^{*}(c)\right]$
Dose: $4.79 E-5(a)$ Interpolation Factor: $-0.084(c)$ Dose: $3.29 E-5(b)$

Interpolated Dose: $3.42 \mathrm{E}-5$

\begin{tabular}{c|ccccccc}
$\begin{array}{c}\text { Wind } \\
\text { Speed } \\
\text { Category }\end{array}$ & A & B & C & D & E & Annual Average Sector-Arc Dose (mrem) \\
\hline 1 & $7.74 \mathrm{E}-06$ & $7.49 \mathrm{E}-06$ & $838 \mathrm{E}-06$ & $1.12 \mathrm{E}-05$ & $3.72 \mathrm{E}-05$ & $1.30 \mathrm{E}-04$ & $0.00 \mathrm{E}+\infty$ \\
2 & $3.60 \mathrm{E}-06$ & $3.33 \mathrm{E}-06$ & $3.48 \mathrm{E}-06$ & $4.01 \mathrm{E}-06$ & $8.79 \mathrm{E}-06$ & $1.75 \mathrm{E}-05$ & $0.00 \mathrm{E}+\infty$ \\
3 & $2.13 \mathrm{E}-06$ & $214 \mathrm{E}-06$ & $2.14 \mathrm{E}-06$ & $2.64 \mathrm{E}-06$ & $5.81 \mathrm{E}-\infty 6$ & $1.20 \mathrm{E}-05$ & $1.89 \mathrm{E}-05$ \\
4 & $1.48 \mathrm{E}-06$ & $1.45 \mathrm{E}-06$ & $1.59 \mathrm{E}-06$ & $1.92 \mathrm{E}-06$ & $4.27 \mathrm{E}-\infty 6$ & $9.02 \mathrm{E}-06$ & $1.44 \mathrm{E}-05$ \\
5 & $1.13 \mathrm{E}-06$ & $0.00 \mathrm{E}+\infty$ & $1.20 \mathrm{E}-06$ & $1.44 \mathrm{E}-06$ & $0.00 \mathrm{E}+\infty$ & $0.00 \mathrm{E}+\infty$ & $0.00 \mathrm{E}+\infty$ \\
6 & $0.00 \mathrm{E}+\infty$ & $0.00 \mathrm{E}+\infty$ & $0.00 \mathrm{E}+\infty$ & $0.00 \mathrm{E}+\infty$ & $0.00 \mathrm{E}+\infty$ & $0.00 \mathrm{E}+\infty$ & $0.00 \mathrm{E}+\infty$
\end{tabular}

Annual Average $=3.829 \mathrm{E}-07$ (average dose weighted by JFD). 


\section{SEMI-INFINITE PLUME GAMMA-SHINE DOSE}

\begin{tabular}{|c|c|c|c|c|}
\hline SECTOR: & NNW & RELHGT $=50$ & $\operatorname{Terrain}(\mathrm{ft})=154.3$ & $\mathrm{XDIS}=11870$ \\
\hline & & Nuclide $=\mathrm{N}-13$ & & Release $(\mathrm{C} i)=1.00 \mathrm{E}+\infty$ \\
\hline & Decay & Int $(1 / \mathrm{sec})=.1 .16 \mathrm{E}-03$ & Ext. DF (mr & $\mathrm{cu} \mathrm{m} / \mathrm{uCi} \mathrm{yr})=5.11 \mathrm{E}+03$ \\
\hline
\end{tabular}

\begin{tabular}{|c|c|c|c|c|c|c|c|}
\hline \multirow{2}{*}{$\begin{array}{c}\text { Wind } \\
\text { Speed } \\
\text { Category }\end{array}$} & \multicolumn{7}{|c|}{$2 \mathrm{br}$ Centerline Dose (mrem) } \\
\hline & A & B & C & D & $\mathrm{E}$ & F & G \\
\hline 1 & $2.21 E-09$ & $5.52 E-09$ & 2.82E-09 & $1.61 E-09$ & $6.72 \mathrm{E}-12$ & $2.10 \mathrm{E}-17$ & $0.00 \mathrm{E}+\infty 0$ \\
\hline 2 & 3.93E-07 & $8.05 E-07$ & $9.53 E-07$ & $1.83 \mathrm{E}-06$ & $4.28 \mathrm{E}-06$ & $1.14 E-05$ & $0.00 \mathrm{E}+\infty 0$ \\
\hline 3 & $1.92 \mathrm{E}-06$ & $2.70 \mathrm{E}-06$ & $3.66 \mathrm{E}-06$ & $5.58 E-06$ & $1.33 E-05$ & $3.16 \mathrm{E}-05$ & $8.98 E-05$ \\
\hline 4 & $3.39 E-06$ & $4.79 E-06$ & $5.78 E-06$ & $9.09 E-06$ & $2.16 \mathrm{E}-05$ & $5.08 E-05$ & $1.35 E-04$ \\
\hline 5 & $4.28 E-06$ & $0.00 \mathrm{E}+\infty 0$ & $7.46 \mathrm{E}-06$ & $1.17 \mathrm{E}-05$ & $0.00 \mathrm{E}+\infty 0$ & $0.00 E+\infty 0$ & $0.00 \mathrm{E}+\infty$ \\
\hline 6 & $0.00 \mathrm{E}+\infty 0$ & $0.00 \mathrm{E}+00$ & $0.00 \mathrm{E}+\infty 0$ & $0.00 \mathrm{E}+\infty 0$ & $0.00 \mathrm{E}+\infty 0$ & $0.00 \mathrm{E}+\infty 0$ & $0.00 \mathrm{E}+\infty$ \\
\hline
\end{tabular}

1st Stab./Speed Cat:: $\quad 6-2$

2nd Stab./Speed Cat: $6-3$

Formula: $b+[(b-a) *(c)]$
Dose: $\left.1.14 E-q_{a}\right) \quad$ Interpolation Factor: $\underline{-0.084 f c)}$ Dose: $\overline{3.16 E-(b)}$

Interpolated Dose: $2.99 E-5$

\begin{tabular}{|c|c|c|c|c|c|c|c|}
\hline \multirow{3}{*}{$\begin{array}{l}\text { Wind } \\
\text { Speed } \\
\text { Category }\end{array}$} & \multicolumn{7}{|c|}{ Annual Average Sector-Arc Dose (mrem) } \\
\hline & \multicolumn{7}{|c|}{ Stability Category } \\
\hline & A & B & C & D & $E$ & $\mathrm{~F}$ & G \\
\hline 1 & $5.13 E-10$ & $7.44 \mathrm{E}-10$ & $1.97 \mathrm{E}-10$ & $1.20 \mathrm{E}-11$ & $1.08 \mathrm{E}-17$ & $6.86 \mathrm{E}-32$ & $0.00 \mathrm{E}+00$ \\
\hline 2 & 2.0TE-07 & 2.98E-07 & $2.43 E-07$ & 2.05E-07 & $9.93 E-08$ & $5.60 \mathrm{E}-08$ & $0.00 \mathrm{E}+\infty 0$ \\
\hline 3 & $1.35 E-06$ & $134 E-06$ & 1.33E-06 & $1.04 \mathrm{E}-06$ & $838 E-07$ & $5.98 \mathrm{E}-07$ & $1.45 \mathrm{E}-06$ \\
\hline 4 & $2.71 E-06$ & $2.80 E-06$ & $2.43 E-06$ & $223 E-06$ & $229 E-06$ & $2.01 E-06$ & $4.23 E-06$ \\
\hline 5 & $3.66 \mathrm{E}-06$ & $0.00 \mathrm{E}+00$ & $3.49 E-06$ & $3.43 E-06$ & $0.00 E+\infty 0$ & $0.00 E+\infty$ & $0.00 \mathrm{E}+\infty$ \\
\hline 6 & $0.00 \mathrm{E}+\infty$ & $0.00 \mathrm{E}+\infty 0$ & $0.00 E+\infty 0$ & $0.00 \mathrm{E}+\infty$ & $0.00 E+00$ & $0.00 E+\infty 0$ & $0.00 E+00$ \\
\hline
\end{tabular}

Annual Average $=4.127 \mathrm{E}-08$ (average dose weighted by JFD) 
SEMI-INFINITE PLUME GAMMA-SHINE DOSE

\begin{tabular}{|c|c|c|c|c|c|c|c|}
\hline SECTOR: & NNW & RELHGT $=$ & & Terrain(ft) = & 1543 & XDIS $=$ & 11870 \\
\hline & & Nuclide $=$ & $F-18$ & & & ease $(\mathrm{Ci})=$ & $1.00 E+\infty 0$ \\
\hline & Decay Cons & $\mathrm{at}(1 / \mathrm{sec})=$ & $1.05 \mathrm{E}-04$ & Ext. & $F$ (mrem cu & $\mathrm{a} / \mathrm{uCi} y r)=$ & $6.62 E+03$ \\
\hline Wind & & & $2 \mathrm{hrC}$ & terline Dos & mrem) & & \\
\hline Speed & & & & bility Categ & & & \\
\hline Category & A & B & C & D & $\mathrm{E}$ & $\mathbf{F}$ & G \\
\hline 1 & $7.04 E-05$ & $935 E-05$ & $1.23 E-04$ & $1.90 \mathrm{E}-04$ & $3.89 \mathrm{E}-04$ & $4.62 E-04$ & $0.00 \mathrm{E}+\infty$ \\
\hline 2 & 5.61E-05 & $7.01 E-05$ & 9.39E-05 & $1.41 \mathrm{E}-04$ & $3.49 \mathrm{E}-04$ & $8.51 E-04$ & $0.00 \mathrm{E}+\infty$ \\
\hline 3 & $4.02 \mathrm{E}-0.5$ & $5.24 \mathrm{E}-05$ & $6.82 E-05$ & $1.06 \mathrm{E}-04$ & 2.65E-04 & $6.63 \mathrm{E}-0.4$ & $1.55 \mathrm{E}-03$ \\
\hline 4 & $3.04 \mathrm{E}-05$ & $3.86 \mathrm{E}-05$ & $5.43 E-05$ & $834 \mathrm{E}-05$ & $2.10 E-04$ & $534 \mathrm{E}-04$ & $1.25 \mathrm{E}-03$ \\
\hline 5 & $243 E-05$ & $0.00 \mathrm{E}+\infty 0$ & 4.28E-05 & $6.56 \mathrm{E}-05$ & $0.00 E+\infty 0$ & $0.00 \mathrm{E}+\infty 0$ & $0.00 \mathrm{E}+\infty$ \\
\hline 6 & $0.00 E+\infty$ & $0.00 \mathrm{E}+\infty 0$ & $0.00 \mathrm{E}+\infty 0$ & $0.00 E+\infty$ & $0.00 \mathrm{E}+\infty 0$ & $0.00 \mathrm{E}+\infty$ & $0.00 \mathrm{E}+\infty$ \\
\hline
\end{tabular}

1st Stab./Speed Cat.: 6-2

2nd Stab./Speed Cat.: $6-3$

Formula: $b+\left[(b-a)^{*}(c)\right]$
Dose: $8.51 E-4 a) \quad$ Interpolation Factor: $-0.0841(c)$ Dose: $\overline{6.63 E-4 b)}$

Interpolated Dose: $6.79 E-4$

\begin{tabular}{|c|c|c|c|c|c|c|c|}
\hline \multirow{2}{*}{$\begin{array}{l}\text { Wind } \\
\text { Speed } \\
\text { Category }\end{array}$} & \multicolumn{7}{|c|}{$\begin{array}{c}\text { Annual Average Sector-Arc Dose (mrem) } \\
\text { Stability Category }\end{array}$} \\
\hline & A & B & C & D & $E$ & $F$ & $G$ \\
\hline 1 & $656 \mathrm{E}-05$ & $659 \mathrm{E}-05$ & $6.47 E-05$ & $6.54 E-05$ & $5.54 E-05$ & $9.01 E-06$ & $0.00 \mathrm{E}+\infty 0$ \\
\hline 2 & $5.63 E-05$ & $5.42 \mathrm{E}-05$ & $5.54 E-05$ & $6.20 \mathrm{E}-05$ & $1.19 \mathrm{E}-04$ & $2.10 \mathrm{E}-04$ & $0.00 \mathrm{E}+\infty 0$ \\
\hline 3 & $4.14 \mathrm{E}-05$ & 4.15E-05 & 4.16E-05 & $4.92 E-05$ & $9.86 \mathrm{E}-05$ & $1.85 E-04$ & $3.04 E-04$ \\
\hline 4 & 3.17E-05 & $3.11 E-05$ & 335E-05 & 3.95E-05 & 8.17E-05 & $159 E-04$ & $260 \mathrm{E}-04$ \\
\hline 5 & $255 \mathrm{E}-05$ & $0.00 \mathrm{E}+\infty$ & $267 E-05$ & $3.16 \mathrm{E}-05$ & $0.00 \mathrm{E}+\infty$ & $0.00 \mathrm{E}+\infty$ & $0.00 \mathrm{E}+\infty$ \\
\hline 6 & $0.00 \mathrm{E}+\infty$ & $0.00 \mathrm{E}+\infty 0$ & $0.00 \mathrm{E}+00$ & $0.00 \mathrm{E}+00$ & $0.00 \mathrm{E}+\infty 0$ & $0.00 \mathrm{E}+00$ & $0.00 \mathrm{E}+00$ \\
\hline
\end{tabular}

Annual Average $=4.734 E-06$ (average dose weighted by JFD). 


\section{SEMI-INFINITE PLUME GAMMA-SHINE DOSE}

\begin{tabular}{|c|c|c|c|c|c|c|c|}
\hline \multirow[t]{3}{*}{ SECTOR: } & \multirow[t]{2}{*}{ NNW } & \multicolumn{2}{|c|}{ RELHGT $=50$} & \multicolumn{2}{|c|}{ Terrain(ft) $=154.3$} & \multicolumn{2}{|c|}{$\mathrm{XDIS}=11870$} \\
\hline & & Nuclide $=$ & $\mathrm{Mg}-27$ & & & $\operatorname{ease}(\mathrm{Ci})=$ & $1.00 \mathrm{E}+00$ \\
\hline & Decay Const & $(1 / \sec )=$ & $1.22 E-03$ & Ext. & F (mrem cu & $a / u C i$ yr) $=$ & $4.67 E+03$ \\
\hline \multirow{3}{*}{$\begin{array}{c}\text { Wind } \\
\text { Speed } \\
\text { Category }\end{array}$} & \multicolumn{7}{|c|}{$2 \mathrm{hr}$ Centerline Dose (mrem) } \\
\hline & \multicolumn{7}{|c|}{ Stability Category } \\
\hline & A & B & $\mathrm{C}$ & D & $\mathrm{E}$ & $F$ & $\mathrm{G}$ \\
\hline 1 & $1.13 E-\infty 9$ & $2.94 E-09$ & $1.43 \mathrm{E}-09$ & $7.67 \mathrm{E}-10$ & $2.25 \mathrm{E}-12$ & $3.40 \mathrm{E}-18$ & $0.00 \mathrm{E}+\infty$ \\
\hline 2 & 2.75E-07 & $5.78 \mathrm{E}-07$ & $6.80 \mathrm{E}-07$ & $133 E-06$ & $3.08 \mathrm{E}-06$ & $8.25 E-06$ & $0.00 \mathrm{E}+\infty$ \\
\hline 3 & $150 \mathrm{E}-06$ & $2.12 E-06$ & $2.87 \mathrm{E}-06$ & $4.38 E-06$ & $1.04 E-05$ & $2.46 \mathrm{E}-05$ & $7.08 \mathrm{E}-05$ \\
\hline 4 & $2.78 E-06$ & $3.94 E-06$ & $4.71 E-06$ & $7.42 E-06$ & $1.76 \mathrm{E}-05$ & $4.12 \mathrm{E}-0.5$ & $1.10 \mathrm{E}-0.4$ \\
\hline 5 & $3.59 E-06$ & $0.00 \mathrm{E}+\infty 0$ & $6.26 \mathrm{E}-06$ & $9.81 E-06$ & $0.00 \mathrm{E}+\infty 0$ & $0.00 \mathrm{E}+\infty$ & $0.00 \mathrm{E}+00$ \\
\hline 6 & $0.00 E+\infty$ & $0.00 \mathrm{E}+\infty$ & $0.00 E+\infty$ & $0.00 \mathrm{E}+\infty 0$ & $0.00 \mathrm{E}+\infty 0$ & $0.00 \mathrm{E}+\infty 0$ & $0.00 \mathrm{E}+\infty$ \\
\hline
\end{tabular}

1st Stab./Speed Cat.: 6-2

2nd Stab./Speed Cat.:
Dose. $8.25 \mathrm{E}-6$ (a) Interpolation Factor: ${ }^{-0.0841}$ (c) Dose2.

Formula: $b+\left[(b-a)^{*}(c)\right]$ Interpolated Dose: $2.32 \mathrm{E}-5$

\begin{tabular}{c|ccccccc}
$\begin{array}{c}\text { Wind } \\
\text { Speed } \\
\text { Category }\end{array}$ & A & B & C & D & E & F & G \\
\hline 1 & $2.44 \mathrm{E}-10$ & $3.61 \mathrm{E}-10$ & $8.85 \mathrm{E}-11$ & $4.59 \mathrm{E}-12$ & $1.89 \mathrm{E}-18$ & $2.08 \mathrm{E}-33$ & $0.00 \mathrm{E}+\infty$ \\
2 & $1.39 \mathrm{E}-07$ & $2.06 \mathrm{E}-07$ & $1.65 \mathrm{E}-07$ & $1.38 \mathrm{E}-07$ & $6.15 \mathrm{E}-08$ & $3.25 \mathrm{E}-08$ & $0.00 \mathrm{E}+\infty$ \\
3 & $1.03 \mathrm{E}-06$ & $1.02 \mathrm{E}-06$ & $1.01 \mathrm{E}-06$ & $7.78 \mathrm{E}-07$ & $5.93 \mathrm{E}-07$ & $4.00 \mathrm{E}-07$ & $9.93 \mathrm{E}-07$ \\
4 & $2.19 \mathrm{E}-06$ & $227 \mathrm{E}-06$ & $1.94 \mathrm{E}-06$ & $1.75 \mathrm{E}-06$ & $1.73 \mathrm{E}-06$ & $1.45 \mathrm{E}-06$ & $3.10 \mathrm{E}-06$ \\
5 & $3.04 \mathrm{E}-06$ & $0.00 \mathrm{E}+\infty$ & $2.88 \mathrm{E}-06$ & $2.80 \mathrm{E}-06$ & $0.00 \mathrm{E}+\infty$ & $0.00 \mathrm{E}+\infty$ & $0.00 \mathrm{E}+\infty$ \\
6 & $0.00 \mathrm{E}+\infty$ & $0.00 \mathrm{E}+\infty$ & $0.00 \mathrm{E}+\infty$ & $0.00 \mathrm{E}+\infty$ & $0.00 \mathrm{E}+\infty$ & $0.00 \mathrm{E}+\infty$ & $0.00 \mathrm{E}+\infty$
\end{tabular}

Annual Average $=3.051 E-08$ (average dose weighted by JFD). 


\section{SEMI-INFINITE PLUME GAMMA-SHINE DOSE}

SECTOR: NNW

$$
\text { RELHGT }=50
$$

$\operatorname{Terrain}(\mathrm{ft})=154.3$

$\mathrm{XDIS}=11870$

Nuclide $=\operatorname{Ar}-41$

Decay Constant $(1 / \mathrm{sec})=1.05 \mathrm{E}-04$

Release $(\mathrm{Ci})=5.00 \mathrm{E}+03$

Ext. DF (mrem cu m/uCi yr) $=6.62 \mathrm{E}+03$

\begin{tabular}{c|ccccccc}
$\begin{array}{c}\text { Wind } \\
\text { Speed } \\
\text { Category }\end{array}$ & A & B & C & Stability Category & D & F & G \\
\hline 1 & $3.51 E-01$ & $4.66 E-01$ & $6.14 E-01$ & $9.45 E-01$ & $1.93 E+\infty$ & $2.28 E+\infty$ & $0.00 E+00$ \\
2 & $2.80 E-01$ & $3.50 E-01$ & $4.69 E-01$ & $7.03 E-01$ & $1.74 E+\infty$ & $4.25 E+\infty$ & $0.00 E+\infty$ \\
3 & $2.01 E-01$ & $2.62 E-01$ & $3.41 E-01$ & $5.32 E-01$ & $1.33 E+\infty$ & $3.31 E+\infty$ & $7.72 E+\infty$ \\
4 & $1.52 E-01$ & $1.93 E-01$ & $2.71 E-01$ & $4.17 E-01$ & $1.05 E+\infty$ & $2.67 E+\infty$ & $6.24 E+\infty$ \\
5 & $1.22 E-01$ & $0.00 E+\infty$ & $2.14 E-01$ & $3.28 E-01$ & $0.00 E+\infty$ & $0.00 E+\infty$ & $0.00 E+\infty$ \\
6 & $0.00 E+\infty$ & $0.00 E+\infty$ & $0.00 E+\infty$ & $0.00 E+00$ & $0.00 E+\infty$ & $0.00 E+\infty$ & $0.00 E+\infty$
\end{tabular}

1st Stab./Speed Cat.: $\quad 6-2$

2nd Stab./Speed Cat::

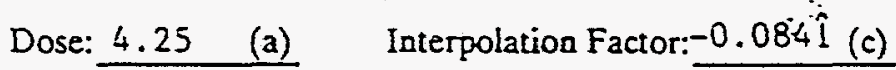
Dose: $3.31 \quad(b)$

Formula: $b+[(b-a) *(c)]$

Interpolated Dose:

3.39

\begin{tabular}{c|ccccccc}
$\begin{array}{c}\text { Wiad } \\
\text { Speed } \\
\text { Category }\end{array}$ & A & B & C & D & E & F & G \\
\hline 1 & $3.27 \mathrm{E}-01$ & $3.28 \mathrm{E}-01$ & $3.22 \mathrm{E}-01$ & $3.25 \mathrm{E}-01$ & $274 \mathrm{E}-01$ & $4.41 \mathrm{E}-02$ & $0.00 \mathrm{E}+\infty$ \\
2 & $2.81 \mathrm{E}-01$ & $2.71 \mathrm{E}-01$ & $2.77 \mathrm{E}-01$ & $3.10 \mathrm{E}-01$ & $5.91 \mathrm{E}-01$ & $1.05 \mathrm{E}+\infty$ & $0.00 \mathrm{E}+\infty$ \\
3 & $2.07 \mathrm{E}-01$ & $2.07 \mathrm{E}-01$ & $2.08 \mathrm{E}-01$ & $2.46 \mathrm{E}-01$ & $4.92 \mathrm{E}-01$ & $9.25 \mathrm{E}-01$ & $1.52 \mathrm{E}+\infty$ \\
4 & $1.58 \mathrm{E}-01$ & $1.55 \mathrm{E}-01$ & $1.67 \mathrm{E}-01$ & $1.97 \mathrm{E}-01$ & $4.08 \mathrm{E}-01$ & $7.96 \mathrm{E}-01$ & $1.30 \mathrm{E}+\infty$ \\
5 & $1.27 \mathrm{E}-01$ & $0.00 \mathrm{E}+00$ & $1.33 \mathrm{E}-01$ & $1.58 \mathrm{E}-01$ & $0.00 \mathrm{E}+\infty$ & $0.00 \mathrm{E}+\infty$ & $0.00 \mathrm{E}+\infty$ \\
6 & $0.00 \mathrm{E}+\infty$ & $0.00 \mathrm{E}+\infty$ & $0.00 \mathrm{E}+\infty$ & $0.00 \mathrm{E}+\infty$ & $0.00 \mathrm{E}+\infty$ & $0.00 \mathrm{E}+\infty$ & $0.00 \mathrm{E}+\infty$
\end{tabular}

Annual Average $=2.363 E-02$ (average dose weighted by JFD). 


\section{SEMI-INFINITE PLUME GAMMA-SHINE DOSE}

SECTOR: NNW RELHGT $=50 \quad$ Terrain $(\mathrm{ft})=154.3 \quad$ XDIS $=11870$

Nuclide $=[-135$

Decay Constant $(1 / \mathrm{sec})=2.92 \mathrm{E}-05$
Release $(\mathrm{Ci})=5.00 \mathrm{E}+\infty 0$

Ext. DF (mrem cu m/uCi yr) $=8.33 E+03$

\begin{tabular}{c|ccccccc}
$\begin{array}{c}\text { Wind } \\
\text { Speed } \\
\text { Category }\end{array}$ & A & B & C & Stability Category \\
\hline 1 & $9.16 E-04$ & $1.16 E-03$ & $1.64 E-03$ & $2.71 E-03$ & $8.66 E-03$ & $2.59 E-02$ & $0.00 E+00$ \\
2 & $4.95 E-04$ & $5.97 E-04$ & $8.06 E-04$ & $1.19 E-03$ & $2.96 E-03$ & $7.16 E-03$ & $0.00 E+\infty$ \\
3 & $3.09 E-04$ & $4.00 E-04$ & $5.20 E-04$ & $8.12 E-04$ & $2.03 E-03$ & $5.09 E-03$ & $1.17 E-02$ \\
4 & $2.20 E-04$ & $2.77 E-04$ & $3.94 E-04$ & $6.03 E-04$ & $1.52 E-03$ & $3.90 E-03$ & $9.04 E-03$ \\
5 & $1.70 E-04$ & $0.00 E+00$ & $3.00 E-04$ & $4.59 E-04$ & $0.00 E+00$ & $0.00 E+\infty 0$ & $0.00 E+\infty$ \\
6 & $0.00 E+\infty$ & $0.00 E+00$ & $0.00 E+\infty$ & $0.00 E+\infty$ & $0.00 E+\infty$ & $0.00 E+\infty$ & $0.00 E+\infty$
\end{tabular}

Stab./Speed Cat.: 6-2

Stab./Speed Cat.: $6-3$

Formula: $b+\left[(b-a)^{*}(c)\right]$
Dose: $\underline{\left.7.16 E-\Psi_{a}\right)}$ Interpolation Factor: -0.0841 (c)

Dose: $\underline{5.09 E-1 \mathrm{~b})}$

\begin{tabular}{c|ccccccc}
$\begin{array}{c}\text { Wind } \\
\text { Speed } \\
\text { Category }\end{array}$ & A & B & C & D & E & S & Annual Average Sector-Arc Dose (mrem) \\
\hline 1 & $9.43 E-04$ & $9.22 E-04$ & $9.94 E-04$ & $1.23 E-03$ & $2.80 E-03$ & $4.19 E-03$ & $0.00 E+\infty$ \\
2 & $5.20 E-04$ & $4.86 E-04$ & $5.05 E-04$ & $5.77 E-04$ & $1.22 E-03$ & $2.35 E-03$ & $0.00 E+\infty$ \\
3 & $3.27 E-04$ & $3.28 E-04$ & $3.28 E-04$ & $4.00 E-04$ & $8.57 E-04$ & $1.73 E-03$ & $2.75 E-03$ \\
4 & $2.33 E-04$ & $2.28 E-04$ & $2.50 E-04$ & $2.99 E-04$ & $6.52 E-04$ & $1.35 E-03$ & $2.16 E-03$ \\
5 & $1.81 E-04$ & $0.00 E+\infty$ & $1.91 E-04$ & $2.29 E-04$ & $0.00 E+\infty$ & $0.00 E+\infty$ & $0.00 E+\infty$ \\
6 & $0.00 E+\infty$ & $0.00 E+\infty$ & $0.00 E+\infty$ & $0.00 E+\infty$ & $0.00 E+\infty$ & $0.00 E+\infty$ & $0.00 E+\infty$
\end{tabular}

Annual Average $=4.755 E-05$ (average dose weighted by JFD). 